Martim Mas e Braga

Frontal system changes in the Southeastern Atlantic Ocean

Master's dissertation submitted to Instituto Oceanográfico da Universidade de São Paulo as partial fulfillment of the requirements for the degree of Master of Science in Oceanography, with emphasis in Physical Oceanography.

Advisor: Ilana Wainer 


\title{
FRONTAL SYSTEM CHANGES IN THE SOUTHEASTERN ATLANTIC OCEAN
}

\author{
Martim Mas e Braga \\ Master thesis submitted to Instituto Oceanográfico of Universidade \\ de São Paulo as partial fulfillment of the requirements for the degree \\ of Master of Science in Oceanography, with emphasis in Physical \\ Oceanography.
}

Evaluated in / / / 2017

$\operatorname{Prof}(a) . \operatorname{Dr}(a)$.

Grade

Prof(a). Dr(a).

Grade

Prof(a). Dr(a).

Grade 


\section{Contents}

1 Introduction $\quad 12$

1.1 The South Atlantic Upper Circulation . . . . . . . . . . . . . . . . . . 12

1.2 The Indian Ocean Upper Circulation . . . . . . . . . . . . . . . . . . . . 13

1.2.1 The Agulhas Region . . . . . . . . . . . . . . . . . . . . . . 14

1.3 The Southern Boundary of the Atlantic Subtropical Gyre . . . . . . . . . . 14

1.4 Fronts at the Atlantic Sector of the Southern Ocean . . . . . . . . . . . 16

1.5 Relevance to the Meridional Overturning Circulation . . . . . . . . . . . 17

2 Motivation $\quad 18$

3 Data and Methods $\quad 20$

3.1 Datasets . . . . . . . . . . . . . . . . . . . 20

3.2 Methods of Analysis . . . . . . . . . . . . . . . . . . 21

3.2 .1 Front Identification . . . . . . . . . . . . . . . . . . . 21

3.2.2 Comparison to the wind field . . . . . . . . . . . . . . . . 21

3.2.3 Comparison to temperature and salinity changes . . . . . . . . . . 22

3.2.4 Evaluation of the velocity fields . . . . . . . . . . . . . . . . 22

3.2.5 Indices for gyre strength and extent . . . . . . . . . . . . . 23

3.2 .6 Other Statistics . . . . . . . . . . . . . . . . . . . . . 23

4 Model Validation $\quad 24$

4.1 Description of the climate-mean fields . . . . . . . . . . . . . . . . 24

4.2 Model biases relative to WOA13 and ORAS4 . . . . . . . . . . . . 25

4.3 Potential Temperature-Salinity diagrams . . . . . . . . . . . . . . . . 32

4.4 Meridional Gradients . . . . . . . . . . . . . . . . . . . . . . . . 32

5 Results and Discussion $\quad 35$

5.1 Ocean Fronts Identification . . . . . . . . . . . . . . . . . . . 35

5.2 Ocean Fronts Variation and Wind Stress Curl . . . . . . . . . . . . . 37

5.3 Temperature and Salinity changes . . . . . . . . . . . . . . . . . . 41

5.4 Velocity and transport changes . . . . . . . . . . . . . . . 45

6 Summary and Conclusions $\quad 51$

7 Supplementary Figures $\quad 62$ 


\section{Agradecimentos}

Um mestrado não é feito por uma pessoa só. Nem por duas. Muitas pessoas tiveram algum papel na construção do que está apresentado nas próximas páginas, por menor (mas não menos importante) que seja. Justamente por isso, tenho muitas pessoas a agradecer pela participação nessa etapa da minha vida que acaba de se encerrar.

Primeiramente, agradeço à minha orientadora, Ilana Wainer, por ter me guiado durante este trabalho (e em todos os anteriores também!). Também aos docentes do IO (especialmente, mas não apenas os com quem tive aula durante a pós), não só pelo ensino dentro de sala, mas pelo apoio e conselhos fora dela inclusive.

Agradeço também a toda a tripulação, pesquisadores e colegas com quem tive a oportunidade de embarcar no "Tio Max", logo no primeiro mês de mestrado! Foram 29 dias a bordo com muitas histórias, risadas, choros e, acima de tudo, muito aprendizado! Com certeza espero rever todos um dia, inclusive o próprio continente gelado. Meu "muito obrigado" vai também a todos do $\mathrm{OC} 2$, pelo apoio e convivência nesses últimos anos: Mineiro, Ferrero, Marina, Laurinha, Fernanda, Zé, Paulo e Gabriel. Um muito obrigado também à Iole, pelo apoio e inúmeras discussões e conselhos (nem sempre) acadêmicos.

Aos meus pais, avós e a toda minha família, que mesmo sem entender direito o que eu faço e fiz, sempre apoiou incondicionalmente todas as minhas escolhas! Não só nesses últimos dois anos, mas pelo menos nos últimos dez. Por falar em dez anos, também devo agradecer aos meus grandes amigos, que apesar de nos vermos com menor frequência, são parceiros há tanto tempo ou até mais: Alan, Lucas e Buffo.

Não só de apoio acadêmico e da família precisamos. Por isso devo agradecer MUITO, MUITO MESMO, a todos aqueles que contribuíram para fazer cada semana mais leve e aturável, por pior que estivesse. Primeiramente, devo agradecer ao CA da biologia (sim, ao espaço físico, mesmo), por ter sido o ambiente de tantas comemorações, conversas e reuniões. Agradeço também a todos do "ForrIO \& Gafieira" (o coletivo de dança de salão alojado no IO), desde os membros da nossa velha guarda até os mais recentes; me alegra ver a continuidade e evolução desse grupo que começou tão pequeno e hoje é enorme! A todos os parceiros de quadra (e também fora dela) do "Ataliba Handebol Mamute", que me devolveram a alegria e garra do handebol após tantos anos parado. Também aos "Demônios de Maxwell", um grupo que em pouquíssimo tempo me cativou e mostrou os valores incríveis desse esporte que é o rugby! Não só a estes aqui citados, mas meu "muito obrigado" vai também a todos e todas que conheci por causa do esporte universitário e que o fazem o acontecer! É uma válvula de escape indispensável para nos mantermos sãos e saudáveis junto aos estudos e à pesquisa. 
Por último, devo agradecer àqueles que conviveram comigo - quase diariamente - não só pelo apoio, mas também por terem conseguido me aguentar durante todos esses anos! À gloriosa Turma Nine, em especial à Bau, Danilo, Luiza, Domo, Camila, Burns, Mariana, Ceci, Lígia e Paulinha! Também à Julia, pela grande parceria e gigantesco apoio ao longo de boa parte dessa jornada. A todos vocês e provavelmente muitos outros que acabei esquecendo de mencionar (mas ainda assim estão no meu coração), meu mais sincero obrigado! Esse trabalho também é de vocês! 


\section{Abstract}

The transition between the South Atlantic and the Southern Ocean is marked by a frontal system that includes both the South Atlantic Current and the Antarctic Circumpolar Current (ACC). In the eastern part of the basin, the latitudinal position of the fronts that compose this system is thought to control the input of warm waters into the Atlantic basin through the Agulhas Leakage. Changes in the Subtropical and Polar regimes associated with the system that marks the boundary between the Subtropical Gyre and the ACC are investigated using the simulation results of the ocean component of the National Center for Atmospheric Research (NCAR) Community Earth System Model (CESM), POP2. Sea surface height gradients and specific contours are used to identify and track the ocean fronts position. We compare the Subtropical Front position at the eastern edge of the South Atlantic to changes in temperature and salinity, as well as Agulhas Current transports and the overlying wind field, in order to determine what could be driving frontal variability at this region and its consequences to volume transport from the Indian into the Atlantic. Results suggest that the Subtropical Front is not the southern boundary of the subtropical gyre, but it responds to changes in the "Supergyre", especially the Indian Ocean Subtropical Gyre expansion.

\section{Resumo}

A transição entre os oceanos Atlântico Sul e Austral é marcada por um sistema frontal que inclui tanto a Corrente do Atlântico Sul quanto a Corrente Circumpolar Antártica (CCA). Na porção oeste da bacia, acredita-se que a posição meridional das frentes que compõem este sistema controla o aporte de águas quentes para o Atlântico pelo Vazamento das Agulhas. Mudanças nos regimes subtropical e polar associadas ao sistema que marca o limite entre o giro subtropical e a CCA são investigadas através dos resultados da componente oceânica do modelo do National Center for Atmospheric Research (NCAR), o Community Earth System Model (CESM), chamada POP2. O gradiente meridional, bem como valores específicos de altura da superfície do mar são usados para identificar e acompanhar a posição destas frentes oceânicas. A comparação da posição da Frente Subtropical no limite leste do Atlântico Sul com as mudanças na temperatura e salinidade, assim como no transporte da Corrente das Agulhas e do campo de ventos sobrejacente, é feita para determinar quais as forçantes da variabilidade frontal nesta região e suas consequências no transporte de volume entre o Índico e o Atlântico. Resultados sugerem que a Frente Subtropical não é o limite sul do giro subtropical, mas responde às mudanças no "Supergiro", especialmente à expansão do Giro Subtropical do Oceano Índico. 


\section{List of Figures}

1.1 South Atlantic and Indian Ocean schematics of the main upper circulation and fronts: Brazil Current, BC; South Atlantic Current, SAC; South Equatorial Current, SEC; Benguela Current, BE; Agulhas Current and Agulhas Return Current, AC and ARC respectively; South Indian Ocean Current, SIOC; Western Australian Current, WAC; Leeuwin Current, LC; Indian Counter Current, ICC; East Madagascar Current, EMC. The Mozambique Channel flow is represented by a series of eddies between Africa and Madagascar, while the eddies that leak into the Atlantic are shown crossing the entire Atlantic basin. Main fronts over the Southern Ocean are listed as: Subtropical Front, STF; Subantarctic Front, SAF; and Polar Front, PF. These compose the transition between the subtropical and polar regimes. Other regions of interest are also identified: (1) the Brazil-Malvinas Confluence, (2) the Agulhas Leakage region and (3) the Indonesian Throughflow. Shading shows mean sea surface temperature (in ${ }^{\circ} \mathrm{C}$ ) of this region. . . . . 15

1.2 Southern Ocean Atlantic sector water mass structure and its associated fronts from Gent (2016). Abbreviations: AABW, Antarctic Bottom Water; LCDW, Lower Circumpolar Deep Water; NADW, North Atlantic Deep Water; UCDW, Upper Circumpolar Deep Water; AAIW, Antarctic Intermediate Water; SAMW, Subantarctic Mode Water; PF, Polar Front; SAF, Subantarctic Front; STF, Subtropical Front. . . . . . . . . . . . . 18

4.1 (a-c) Mean sea surface temperature fields from (a) ORAS4; (b) POP2; (c) WOA13. (d, e) Difference between POP2 and (d) ORAS4; (e) WOA13. . . 25

4.2 (a-c) Mean sea surface salinity fields from (a) ORAS4; (b) POP2; (c) WOA13. (d, e) Difference between POP2 and (d) ORAS4; (e) WOA13. . . 26

4.3 (a,b) Mean sea surface height fields from (a) ORAS4; (b) POP2 and (c) the difference between POP2 and ORAS4. . . . . . . . . . . . 27

4.4 Mean surface zonal velocities fields from (a) ORAS4; (b) POP2 and (c) the difference between POP2 and ORAS4. . . . . . . . . . . . . . . 28

4.5 Mean meridional SST gradient fields from (a) ORAS4; (b) POP2; (c) WOA13; (d, e) mean meridional SSH gradients from ORAS4 and POP2. . 28

4.6 Meridional transects at Greenwich for $(\mathrm{a}, \mathrm{b})$ ORAS4; (c,d) POP2; (e,f) WOA13. Upper panels show salinity sections and lower panels show potential temperature sections $\left({ }^{\circ} \mathrm{C}\right) \ldots \ldots \ldots \ldots \ldots$

4.7 Meridional transects at $20^{\circ} \mathrm{E}$ for (a,b) ORAS4; (c,d) POP2; (e,f) WOA13. Upper panels show salinity sections and lower panels show potential temperature sections $\left({ }^{\circ} \mathrm{C}\right) . \ldots \ldots \ldots$. . . . . . . . . . . . . 30

4.8 Meridional transects at $30^{\circ} \mathrm{E}$ for (a,b) ORAS4; (c,d) POP2; (e,f) WOA13. Upper panels show salinity sections and lower panels show potential temperature sections $\left({ }^{\circ} \mathrm{C}\right) \ldots \ldots \ldots \ldots \ldots$ 
$4.9 \theta$-S diagrams at Greenwich $\left(0^{\circ}\right)$ from 35 to $65^{\circ} \mathrm{S}$ for (a) WOA13; (b) POP2; (c)ORAS4. . . . . . . . . . . . . . . . . . 33

4.10 - -S diagrams for (a) ORAS4; (b) POP2 as in Fig. 13.13 of Talley et al. (2011). (Red) Subantarctic Zone profile at 39 S, $0^{\circ} \mathrm{E}$; (Blue) Polar Frontal Zone profile at $48^{\circ} \mathrm{S}, 1^{\circ} \mathrm{E}$; (Magenta) Antarctic Zone profile at $61^{\circ} \mathrm{S}, 1^{\circ} \mathrm{E}$. Also shown on panel (a) are the different water masses found at each profile. Water mass names were omitted from panel (b) for a better visualisation of the profiles. Red dots are shown as a reference for an easier comparison between the water types on both figures. . . . . . . . . . . . . . . . 3

4.11 Meridional (upper) SSH and (lower) SST gradients for (solid lines) ORAS4; (dashed lines) POP2; (dotted lines) WOA13. panels (a,b) show gradients at Greenwich, $(\mathrm{c}, \mathrm{d})$ at $20^{\circ} \mathrm{E}$ and $(\mathrm{e}, \mathrm{f})$ at $30^{\circ} \mathrm{E}$. . . . . . . . . . . . . 34

5.1 Upper panels: Meridional SSH gradients and SSH values from 30 to $60^{\circ} \mathrm{E}$ from ORAS4 (solid, red) and POP2 (dashed, blue) at (a) $0^{\circ}$, (b) $20^{\circ}$, (c) $30^{\circ} \mathrm{E}$. Red and blue lines represent SSH, whereas black lines represent the SSH gradients. Middle panels: potential temperature cross-sections from POP2 at (d) $0^{\circ}$, (e) $20^{\circ}$, (f) $30^{\circ}$ E. Lower panels: salinity cross-sections from POP2 at (g) $0^{\circ}$, (h) $20^{\circ}$, (i) $30^{\circ}$ E. . . . . . . . . . . . . . . . 35

5.2 Cross-sections averaged between $20^{\circ} \mathrm{E}$ and $30^{\circ} \mathrm{E}$ of (a) Meridional SSH gradients (solid line) and SSH values (marked line); (b) Potential Temperature $\left({ }^{\circ} \mathrm{C}\right)$; (c) Salinity. Vertical dashed lines show the SAF (south) and STF (north) mean positions for an easier comparison between the three panels.

5.3 Meridional SSH gradient (shading) and SSH (contours) for the Agulhas region. (a) first five years average (1970-1974) and (b) last five years average (2005-2009). Purple line shows the $0.15 \mathrm{~m}$ contour used to track the STF position.

5.4 (a) Meridional SSH gradient mean for the 1970-2009 period (shading) and SSH contours for the STF mean position. Magenta line shows the 19701974 average and dark purple line shows the 2005-2009 average. (b) Time series of the deviations from the STF mean position between 1970 and 2009. 37

5.5 Wind Stress Curl (WSC; shading) and sea surface height (contours) for the Agulhas region. (a) first five years average (1970-1974) and (b) last five years average (2005-2009). Turquoise line shows the $-1.1 \mathrm{~m}$ contour used to track the SAF position.

5.6 Meridional profile of SSH zonally averaged from $20^{\circ} \mathrm{E}$ to $30^{\circ} \mathrm{E}$ (red) and of zonally averaged WSC between $20^{\circ} \mathrm{E}$ and $100^{\circ} \mathrm{E}$ (dark blue). Solid lines represent the 1970-1974 average, while dashed lines represent the 20052009 average. Black triangles show where the SAF and the STF are located on the SSH curves. 
5.7 (a) Wind stress curl trends (shading) in $10^{-8} \mathrm{Nm}^{-3} \mathrm{dec}^{-1}$. Dark blue lines show the position of WSC0 for the first 5 (solid) and last 5 (dashed) years mean. (b) Decadal means Meridional profile of the Atlantic wind field $\left(40^{\circ} \mathrm{W}\right.$ to $20^{\circ} \mathrm{E}$ zonal average) in $\mathrm{m} / \mathrm{s}$; (c) Decadal means Meridional profile of the Indian wind field (50 to $100^{\circ} \mathrm{E}$ zonal average) in $\mathrm{m} / \mathrm{s}$; colors in both profiles show 70-79 (yellow), 80-89 (blue), 90-99 (turquoise) and 00-09 (purple) means. (d) Time series of wind stress curl $\left(10^{-8} \mathrm{Nm}^{-3}\right)$ averaged over $40-20^{\circ} \mathrm{S}$ and $50-100^{\circ} \mathrm{E}$ under a 12 -month running mean. The red dashed line shows the statistically significant (at 95\% confidence) linear trend between 1982 and 2009 trying to replicate the trend found by Rouault et al. (2009). . . . . . . . . . . . . . . . . . . . . . . . . 40

5.8 (a) Map of SST trends over the Agulhas region and (b) SST time series averaged over the region shown by the red box, which is the region of Agulhas Leakage in POP2. The lines represent the STF (purple) and SAF (black) associated contours. Solid lines represent the 1970-1974 mean and dashed lines represent the 2005-2009 mean. . . . . . . . . . . . . . . . . . 42

5.9 (a) Map of Sea Surface Salinity (SSS) trends over the Agulhas region and (b) SSS time series averaged over the region shown by the red box, which is the region of Agulhas Leakage in POP2. The lines represent the STF and the SAF as in Fig.5.8. . . . . . . . . . . . . . . . . . . . . 42

5.10 Changes in temperature and salinity from the Indian to the Atlantic. (a,b) Model precipitation flux trends (shading; $10^{-5} \mathrm{~kg} \mathrm{~m}^{-2} \mathrm{~s}^{-1} /$ decade) and surface salinity trends (contours; drawn every $0.05 \mathrm{~g} / \mathrm{kg} \mathrm{decade}^{-1}$ in [a] and every $0.2 \mathrm{~g} / \mathrm{kg} \mathrm{decade}^{-1}$ in [b]). The difference in scale was kept for trends to be visible in both plots. (a) shows 1980-2002 trends and (b) shows 20022009 trends. (c) Changes in precipitation (blue) and salinity (black) over the central Indian Ocean $\left(30-100^{\circ} \mathrm{E}, 40-10^{\circ} \mathrm{S}\right)$ and $(\mathrm{d})$ their normed crosscorrelation function. (e) Mean decadal (solid) salinity and (dashed) heat fluxes towards the Atlantic through the model's Agulhas Leakage. Colours denote same decades as in previous decadal profiles. (f) Upper $1500 \mathrm{~m}$ salt transport $\left[10^{9} \mathrm{~kg} / \mathrm{s}\right]$ towards the Atlantic through the "Leakage Current". . 43

$5.11 \theta$-S diagram for waters north of the STF mean position. Decadal means are shown: (brown) 1960-1969; (blue) 1980-1989; (magenta) 2000-2009. . 44

5.12 Streamlines of the surface velocity over the Agulhas region. Colors show velocity values in $\mathrm{m} / \mathrm{s}$. The lines show the transects at $20^{\circ} \mathrm{E}$ and $30^{\circ} \mathrm{E}$ for reference. 
5.13 (a) Meridional cross-section of mean zonal velocity (shading, $\mathrm{m} / \mathrm{s}$ ) and its trend (each line denotes a $0.2 \mathrm{~cm} / \mathrm{s} \mathrm{month}^{-1}$ trend; solid for positive and dashed for negative) at $20^{\circ} \mathrm{E}$. (b) Solid lines show time series of Agulhas leakage transport anomaly (gray, Sv; $1 \mathrm{~Sv}=10^{6} \mathrm{~m}^{3} / \mathrm{s}$ ) for the dotted area in (a) and its 12-month running mean (black). The dash-dotted line shows the STF deviation from its mean position in kilometers as in Fig. 5.4, but under a 12-month running mean. . . . . . . . . . . . . . . . . . . 46

5.14 (a) Eddy Kinetic Energy trends (shading; $\mathrm{m}^{2} \mathrm{~s}^{-2}$ ) and mean values (contours only represent regions of highest EKE corresponding to the Agulhas Current and to the Agulhas Leakage). (b) Eddy Kinetic Energy at $20^{\circ} \mathrm{E}$ over the Agulhas Leakage Current. Trend listed in red for the 1985-2009 period for comparison with the work of Beal \& Elipot (2016). . . . . . . . 47

5.15 Transport (in Sv) time series of (a) Agulhas Current at $30^{\circ} \mathrm{E}$ and (b) $\mathrm{Ag}$ ulhas Return Current at $30^{\circ} \mathrm{E} . \ldots \ldots \ldots$. . . . . . . . . . . 48

5.16 (a) Barotropic Stream Function (Sv) over the Supergyre: 1970-2009 average represented by the shading while positive (negative) trends are represented by solid (dashed) contours; (b) Meridional profile of the BSF at $20^{\circ} \mathrm{E}$; (c) Meridional profile of the BSF over the Indian Ocean $\left(50-100^{\circ} \mathrm{E}\right.$ average). . . . . . . . . . . . . . . . . .

5.17 (a) Variation of the meridional position of averaged BSF0 between $60^{\circ} \mathrm{W}$ and $30^{\circ} \mathrm{W}$ (dark blue), $30^{\circ} \mathrm{W}$ and $0^{\circ}$ (blue), $0^{\circ}$ and $30^{\circ} \mathrm{E}$ (purple), $30^{\circ} \mathrm{E}$ and $60^{\circ} \mathrm{E}$ (turquoise), $60^{\circ} \mathrm{E}$ and $90^{\circ} \mathrm{E}$ (brown), and the STF (black). All series had their seasonal cycles removed and only the BSF0 series had a 12-month running mean applied to them. (b) Linear trends of the series shown in (a) in terms of deviation from their mean position (in $\mathrm{km}$ ). Trends and series were separated for clarity. . . . . . . . . . . . . . . . . . . . 50

5.18 Twelve-month running means of (a) Gyre strength for the Supergyre (black) and separately for the Atlantic (blue) Indian (red) oceans. (b) Gyre extent (in $10^{6} \mathrm{~km}^{2}$ ) colour-coded as in (a). Gyre strength was calculated as the average BSF over the region where it is negative. Extent was calculated as the area integral over the region where BSF is negative. . . . . . . . . . . 50

7.1 Difference between mean temperature fields at (a,b) $200 \mathrm{~m}$, (c, d) $300 \mathrm{~m}$, (e, f) $900 \mathrm{~m}$ between POP2-ORAS4 and POP2-WOA13.

7.2 Difference between mean salinity fields at (a,b) $200 \mathrm{~m},(\mathrm{c}, \mathrm{d}) 300 \mathrm{~m},(\mathrm{e}, \mathrm{f})$ 900 m between POP2-ORAS4 and POP2-WOA13. . . . . . . . . . . . . 62

7.3 Standard deviation of (a-c) SST fields from ORAS4, POP2 and WOA13 respectively; (d to f) SSS fields from ORAS4, POP2 and WOA13 respectively. 63

7.4 Standard deviation of $(\mathrm{a}, \mathrm{b})$ zonal velocity fields from ORAS4 and POP2 respectively; (c, d) SSH fields from ORAS4 and POP2 respectively. . . . . 64 
7.5 Figure 13.7 of Talley et al. (2011): Potential temperature-salinity relations for the Atlantic Ocean (Greenwich meridian), encompassing the fronts and zones of the ACC. Contours are potential density $\sigma \_\theta(\mathrm{kg} / \mathrm{m} 3)$. Line near bottom is the freezing point. Acronyms: SAZ (Subantarctic Zone), SAF (Subantarctic Front), PFZ (Polar Frontal Zone), PF (Polar Front), AZ (Antarctic Zone), SACCF (Southern ACC Front). . . . . . . . . 65

7.6 Figure 13.13 of Talley et al. (2011): Potential temperature-salinity curve of Southern Ocean waters in the Atlantic sector showing the different water masses. . . . . . . . . . . . . . . . . . . . . . . . 65

\section{List of Tables}

5.1 Summary of both fronts identified, listing contours used for identification, their mean position and trends (in $\mathrm{km} /$ decade). Trends are significant over the $95 \%$ level. . . . . . . . . . . . . . . . . . . . . . . 39

5.2 Lagged Pearson correlation coefficients between relevant indexes and variables. $R_{\max }$ stands for the maximum correlation, followed by its lag. $R_{0}$ denotes the correlation at zero lag. All results are significant over 95\%. Series were compared under a 12-month running mean unless otherwise noted in the text (e.g., Gyre indices). . . . . . . . . . . . . . . . . 51 


\section{List of Acronyms}

AC Agulhas Current

ACC Antarctic Circumpolar Current

AMOC Atlantic Meridional Overturning Circulation

ARC Agulhas Return Current

BC Brazil Current

BE Benguela Current

BSF Barotropic Stream Function

CESM Community Earth System Model

CORE Coordinated Ocean-Ice Reference Experiments

DSTF Dynamical Subtropical Front

EKE Eddy Kinetic Energy

EMC East Madagascar Current

ENSO El Niño Southern Oscillation

ICC Indian Counter Current

LC Leeuwin Current

LCDW Lower Circumpolar Deep Water

MOC Meridional Overturning Circulation

NADW North Atlantic Deep Water

NCAR National Center for Atmospheric Research

ORAS4 Ocean Reanalysis System 4

PF Polar Front

PFZ Polar Front Zone

POP Parallel Ocean Program

SAC South Atlantic Current

SACCF South ACC Front

SAF Subantarctic Front

SAMW Subantarctic Mode Water

SAZ Subantarctic Zone

SEC South Equatorial Current

SIOC South Indian Ocean Current

SSH Sea Surface Height

SSS Sea Surface Salinity

SST Sea Surface Temperature

STF Subtropical Front

STFZ Subtropical Frontal Zone

WAC Western Australian Current

WOA13 World Ocean Atlas 2013

WSC Wind Stress Curl 


\section{Introduction}

\subsection{The South Atlantic Upper Circulation}

The Atlantic Ocean is the narrowest of all oceans and the only one with a net northward transport from the southern to the northern hemisphere. This happens due to the anomalous transport of warmer waters from higher towards lower latitudes over the South Atlantic (Macdonald and Wunsch, 1996). Because of the relative position of the African continent to the latitude of maximum westerly winds, Sverdrup dynamics allows relatively warmer and saltier waters from the Indian Ocean to enter the Atlantic basin and be carried north (Beal et al., 2011).

The South Atlantic subtropical gyre is limited on the western side by the Brazil Current, a western boundary current that flows south until it meets the northward flowing Malvinas Current (Silveira et al., 2000; Piola and Matano, 2001). The latter can be regarded as the northernmost branch of the Antarctic Circumpolar Current (ACC). This is known as the Brazil-Malvinas Confluence, a region of high seasonal and interannual variability due to the strong interaction between the two current systems (Wainer et al., 2000; Piola and Matano, 2001; Goni and Wainer, 2001; Lumpkin and Garzoli, 2011). As the confluent currents flow eastward, they separate into two currents: the South Atlantic Current and the northern branch of the ACC, associated with the Subantarctic Front (SAF). These two currents are considered the dynamical boundaries of the South Atlantic and the Southern Ocean, respectively (Stramma and Peterson, 1990; Peterson and Stramma, 1991; Orsi et al., 1995). Part of this system extends all the way into the Indian Ocean acting as a meridional barrier for exchanges between the Southern Ocean and the subtropics (Speich et al., 2007). Thus, these currents and associated oceanic fronts mark the transition between the subtropical and polar dynamical regimes not only in the South Atlantic but in all southern hemisphere basins (Sokolov and Rintoul, 2009a).

At the southeastern side of the Atlantic basin, the South Atlantic Current is much weaker and separates into a northward (back into the South Atlantic) and an eastward flow (into the Indian Ocean). The former is known as the Benguela Current and is composed by both South Atlantic waters and Indian Ocean waters, entering the Atlantic at the Agulhas region (Lutjeharms and Van Ballegooyen, 1988; Speich et al., 2007; Biastoch et al., 2008). As it flows north, it becomes part of the South Equatorial Current, eventually reaching the Brazilian coast and bifurcating southward (recirculating into the Brazil Current) and northward as the North Brazil Current (Stramma, 1991; da Silveira et al., 1994; Zhang et al., 2011). The waters that enter this current are carried to the North Atlantic, eventually reaching the high latitudes as part of the Meridional Overturning Circulation (MOC) (Talley, 2013). These currents are depicted in Fig.1.1. 


\subsection{The Indian Ocean Upper Circulation}

Contrary to the Pacific and Atlantic, the Indian Ocean is constrained to the north by the Eurasian supercontinent. Thus, only a southern hemisphere subtropical gyre exists in this ocean. North of the gyre, the ocean circulation is dominated by the monsoon system (Gordon et al., 1997).

The western boundary of the Indian Subtropical gyre, due to the existence of Madagascar, is composed by the East Madagascar Current and a turbulent flow across the Mozambique Channel. These two merge south of Madagascar with recirculated waters to form the southwest flowing Agulhas Current (Penven et al., 2006). The Agulhas Current then veers to the west south of Africa (following the bathymetry) until it retroflects back into the Indian Ocean as the Agulhas Return Current (ARC; details about the Agulhas system are discussed further below). Far from the western side of the basin, this current is regarded as the South Indian current, which is associated with the Subtropical Front, hereafter STF (Stramma, 1992). This current flows east until about 90 to $100^{\circ} \mathrm{E}$, where it veers northeastward, becoming the West Australian Current (Stramma and Lutjeharms, 1997). The South Indian Ocean Current starts as the most intense subtropical gyre south boundary current but, due to intense recirculation, it weakens towards the eastern side of the basin; this also helps to enhance the South Equatorial Current, which is much stronger than its counterparts over other basins (Stramma and Lutjeharms, 1997). Between 50 and $70^{\circ} \mathrm{E}$, the South Indian Ocean Current is steered by topography, bringing it closer to the $\mathrm{SAF}$ at about $80^{\circ} \mathrm{E}$ and allowing cross-frontal mixing between the subtropical gyre and the ACC (Sparrow et al., 1996). Unlike the Atlantic, a counter-current inside the subtropical gyre exists, and it is called the Indian Counter Current. It is located between 22 and $26^{\circ} \mathrm{S}$ and is fed by the East Madagascar Current retroflection, reaching as far as $100^{\circ} \mathrm{E}$ (Siedler et al., 2006; Palastanga et al., 2007). Nevertheless, most of the Indian Ocean recirculation is concentrated in the southwestern part of the basin due to topography (Stramma and Lutjeharms, 1997).

Contrary to the other southern subtropical gyres, the Indian South Equatorial Current (ISEC) has a zonal flow, mainly supplied by the Indonesian Throughflow (Godfrey, 1996; Gordon et al., 1997; Stramma and Lutjeharms, 1997). As a result, it carries fresher water from the Pacific Ocean within its flow. The Indonesian Throughflow also causes its eastern boundary current, called the Leeuwin Current (LC), to flow polewards (Schott et al., 2009). As a consequence, the closure of the subtropical gyre is done by the recirculating waters from the SIOC and the West Australian Current, which is located further away from the western Australian coast (Andrews, 1977; Stramma, 1992).

The ISEC bifurcates when it reaches the western side close to Madagascar, becoming the Northeast and Southeast Madagascar Currents (Schott et al., 2009). The former branches north, as the East African Coastal Current (which is not part of the subtropical gyre), and south, to supply waters to the Mozambique Channel flow, thus closing the gyre. Variability from the Indonesian Throughflow is then carried into the entire subtropical 
gyre, forcing changes at interdecadal timescales originated from the Pacific (Reason et al., 1996). The Indian Ocean itself was also shown to have a global influence on climate at many timescales, from intraseasonal to secular, primarily but not exclusively through the El Niño Southern Oscillation (ENSO) and the Indian Ocean Dipole (Schott et al., 2009). These currents are depicted in Fig.1.1.

\subsubsection{The Agulhas Region}

South of Africa, at the transition between the Indian and the Atlantic oceans, lies the Agulhas region. There, relatively warmer and saltier waters enter the Atlantic at the first 1000 to $1600 \mathrm{~m}$ through the Agulhas Leakage (Bryden and Beal, 2001; Rouault et al., 2009; Beal et al., 2011). This happens due to the fact that the line where wind stress curl (WSC) is zero is located south of the African continent and thus not interrupted by any landmass between the two ocean basins. As a consequence, it allows waters to be transported meridionally (due to Sverdrup dynamics), forming a "supergyre" (Speich et al., 2007). The connection between both subtropical gyres is mainly given by waters shed from the retroflection of the Agulhas Current.

The Agulhas Current separates from the southeastern African coast and veers westwards towards the Atlantic Ocean (Ou and De Ruijter, 1986). South of Africa, at about 16 to $20^{\circ} \mathrm{E}$, it retroflects to conserve potential vorticity; positive (i.e., counter-clockwise) relative vorticity has to be generated to compensate for the "more negative" planetary vorticity (since waters move further south) and increase in depth (Gill and Schumann, 1979; Lutjeharms and Van Ballegooyen, 1984; de Ruijter and Boudra, 1985; Lutjeharms and Van Ballegooyen, 1988). Then, it flows eastward back into the Indian Ocean as the Agulhas Return Current (ARC) (Quartly and Srokosz, 1993). This retroflection, as it moves westwards and forms a progressively tighter loop, sheds its relatively warmer and saltier waters into the Atlantic as a way of going back to a more stable state (Lutjeharms and Van Ballegooyen, 1988). Most of the Agulhas Current waters come from the recirculation at the southwestern Indian subgyre and by a diffusive flow east of Madagascar (i.e., the East Madagascar Current; Stramma and Lutjeharms, 1997).

The waters that leak into the Atlantic are then carried northwards in the form of rings and filaments (Boebel et al., 2003). More importantly, their properties are preserved at the thermocline and intermediate depths (Gordon et al., 1992) as it crosses the Atlantic. This mechanism is very important for the global climate, as it is able to transport heat and salt into the North Atlantic high latitudes (Beal et al., 2011). This region and its currents are also depicted in Fig.1.1.

\subsection{The Southern Boundary of the Atlantic Subtropical Gyre}

Ocean fronts (such as the STF and the SAF) are regions of transition between different dynamic and thermodynamic regimes or between water masses. These regions can be 


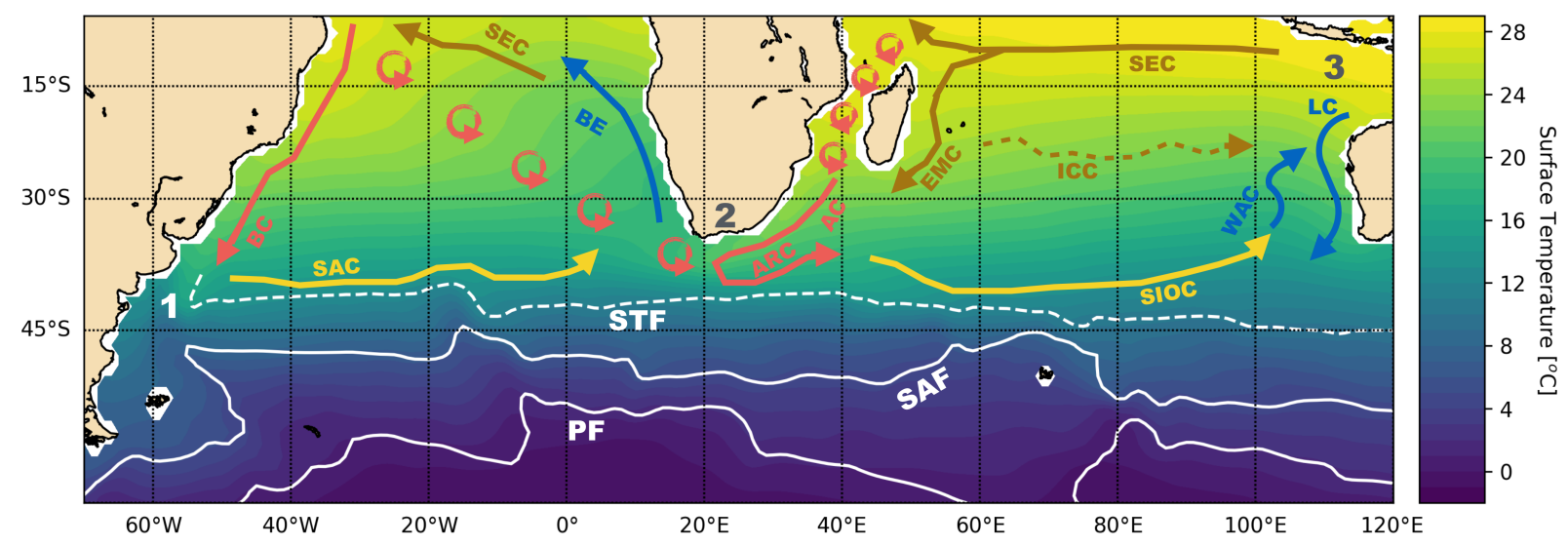

Figure 1.1: South Atlantic and Indian Ocean schematics of the main upper circulation and fronts: Brazil Current, BC; South Atlantic Current, SAC; South Equatorial Current, SEC; Benguela Current, BE; Agulhas Current and Agulhas Return Current, AC and ARC respectively; South Indian Ocean Current, SIOC; Western Australian Current, WAC; Leeuwin Current, LC; Indian Counter Current, ICC; East Madagascar Current, EMC. The Mozambique Channel flow is represented by a series of eddies between Africa and Madagascar, while the eddies that leak into the Atlantic are shown crossing the entire Atlantic basin. Main fronts over the Southern Ocean are listed as: Subtropical Front, STF; Subantarctic Front, SAF; and Polar Front, PF. These compose the transition between the subtropical and polar regimes. Other regions of interest are also identified: (1) the BrazilMalvinas Confluence, (2) the Agulhas Leakage region and (3) the Indonesian Throughflow. Shading shows mean sea surface temperature (in ${ }^{\circ} \mathrm{C}$ ) of this region.

identified by strong gradients of properties such as temperature and salinity throughout the water column (e.g., Orsi et al., 1995) and, at least in most cases, also sea surface height (e.g., Sokolov and Rintoul, 2009a). In the South Atlantic, the transition between its southern boundary and the waters around Antarctica is marked by a series of fronts, most of them part of the ACC System (Orsi et al., 1995; Rintoul et al., 1999; Carter et al., 2008).

The STF is historically regarded as the limit of the Subtropical Gyre. It is defined as the boundary between two water masses of different regimes and very distinct properties (e.g., temperature, salinity, density, oxygen and nutrient concentrations). Therefore, it can be identified by the maximum horizontal gradients or by the specific contours of such properties (Orsi et al., 1995; Belkin and Gordon, 1996; Sokolov and Rintoul, 2009a; Dencausse et al., 2011).

Its meridional position varies zonally, as it separates from the Brazil-Malvinas Confluence at roughly $37^{\circ} \mathrm{S}$, veers southward and goes back to $40^{\circ} \mathrm{S}$ at $40^{\circ}$ to $50^{\circ} \mathrm{W}$ (Belkin and Gordon, 1996; Sokolov and Rintoul, 2009a,b; Lumpkin and Garzoli, 2011, shown in Fig.1.1). The STF latitude remains the same until east of $40^{\circ} \mathrm{W}$ and then bifurcates close to Africa into two branches. Its northern branch joins the Benguela Current and 
its southern branch flows into the Indian Ocean south of the Agulhas Front, which is associated with the ARC and thus part of the leakage system (Belkin and Gordon, 1996; Ruijter et al., 1999). Dencausse et al. (2011), however, suggest the STF and the Agulhas Front might merge and not be distinguishable from each other south of Africa.

Deacon (1982) first associated the position of the STF with the zero wind stress curl line (WSC0) calling it the "Subtropical Convergence". The WSC0 line is considered the atmospheric boundary of the Subtropical Gyre due to Sverdrup dynamics. Boer et al. (2013), on the other hand, found this line to be located $10^{\circ}$ south of the STF, and therefore over the ACC. The association between the WSC0 and STF positions meant that this boundary location would serve as a "gateway" for the amount of relatively warmer and saltier waters that could enter the Atlantic as the MOC upper branch (Peeters et al., 2004; Biastoch et al., 2009). Boer et al. (2013) also discuss the possibility that WSC0 could be related to the Subantarctic Front instead.

Boer et al. (2013) and Graham and Boer (2013) have also shown that the STF may be viewed as a composition of two distinct systems in each side of an ocean basin in the southern hemisphere. At the western side, the STF can be regarded as a dynamical boundary (called Dynamical Subtropical Front - DSTF). In the Atlantic, it is associated with the South Atlantic Current. At the eastern side of any given basin, the STF is considered to be a zone of several lesser temperature and salinity gradients representing the water mass boundaries called the Subtropical Frontal Zone (STFZ). The Indian Ocean's DSTF is associated with the ARC and therefore can be found south of Africa right at the Atlantic Ocean's eastern boundary. It coincides with the STF's southern branch of Dencausse et al. (2011).

\subsection{Fronts at the Atlantic Sector of the Southern Ocean}

South of the STF, the ocean is dominated by the ACC. This current is composed by a series of circumpolar jets that flow along its fronts: the Subantarctic Front (SAF), the Polar Front (PF) and the South ACC Front (SACCF) (Orsi et al., 1995; Belkin and Gordon, 1996; Sokolov and Rintoul, 2009a). The SAF is the northernmost front of the ACC, located close to South America at the Drake Passage, veering north downstream and reaching $45^{\circ} \mathrm{S}$ at the Greenwich meridian (Orsi et al., 1995; Belkin and Gordon, 1996). It can be identified both as a maximum in the SSH gradient field and by the sinking of a less saline subsurface water tongue, which is associated with the Antarctic Intermediate Water (Whitworth and Nowlin, 1987; Orsi et al., 1995; Sokolov and Rintoul, 2002, 2009a).

Between the ACC fronts, there are zones where properties show little variation and are named after its southern boundary. Therefore, the region north of the SAF is the Subantarctic Zone (SAZ) and to its south lies the Polar Front Zone (PFZ), which is bounded to the south by the PF (Fig. 1.1). This front is found at about $50^{\circ} \mathrm{S}$ east of $40^{\circ} \mathrm{W}$ and can be identified by strong gradients in density, temperature, salinity and by high geostrophic velocities as well as by the northern edge of a subsurface temperature minimum (Deacon, 
1933; Mackintosh, 1946; Orsi et al., 1995; Moore et al., 1999). It is between the SAF and the PF where the formation of Antarctic Intermediate Water (AAIW) and Subantarctic Mode Water (SAMW; a precursor to the AAIW) occurs (England, 1992; Sloyan and Rintoul, 2001; Gent, 2016). To the south of the PF lies the SACCF and the Southern Boundary. The SACCF can only be identified by a strong gradient in subsurface temperature and salinity (i.e., a transition between different water masses) despite being a dynamical feature. The Southern Boundary, however, is not a dynamical feature as it only marks the southernmost extent of the ACC. It is the limit between the ACC regime and the Weddell Sea regime and can be viewed as the southernmost extent of the Upper Circumpolar Deep Water (UCDW), one of the main water masses carried by the ACC (Stramma and Peterson, 1990; Peterson and Stramma, 1991; Orsi et al., 1995). These fronts and the associated water mass structure are shown in Fig. 1.2.

Many studies (e.g., Orsi et al., 1995; Belkin and Gordon, 1996; Sokolov and Rintoul, 2009a,b; Dencausse et al., 2011) discuss the location of the ACC Frontal System, which is present in all ocean basins, but at different latitudes around Antarctica. This happens mainly due to the strong influence of topography on the mean flow (Belkin and Gordon, 1996; Sokolov and Rintoul, 2002; Boer et al., 2013). Topography also plays a role in the branching and merging of these fronts, sometimes dividing them into three or even more branches (Sokolov and Rintoul, 2009a; Dencausse et al., 2011). Still, the position of such fronts is subject to variability at many timescales. For example, Boer et al. (2013) show that their DSTF and STFZ show different seasonal variations of their position, while the ACC fronts show a seasonal variation of their properties but not as much of their position (Moore et al., 1999; Graham and Boer, 2013).

\subsection{Relevance to the Meridional Overturning Circulation}

The South Atlantic Ocean plays a crucial role in the regulation of global climate, as both warm and cold branches of the MOC flow through it (Garzoli and Matano, 2011; Talley, 2013). The cold branch is composed by the deep southward flow of North Atlantic Deep Water, which is carried from the Labrador Sea all the way south to the ACC. At the South Atlantic, it flows close to the South American coast, eventually flowing with the Brazil Current until it reaches the Southern Ocean and becomes part of the CDW (Orsi et al., 1993, 1995; Orsi and Wiederwohl, 2009). It is balanced by a northward return flow of surface and thermocline waters that are redistributed from the Southern Ocean to the Pacific and Indian ocean basins before returning to the Atlantic through the warm branch (Speich et al., 2007; Talley, 2013), i.e., through the Agulhas Leakage. The waters that leaked into the Atlantic are eventually advected to the North Atlantic carried by the North Brazil Current (van Sebille et al., 2011) and its variability was shown to respond to changes in the wind field at short timescales (Biastoch and Böning, 2013). The part of the MOC system that is present in the Atlantic basin is more specifically called the Atlantic MOC, also known as AMOC. 
The Indian Ocean itself has a smaller meridional overturning cell, with northward flowing deep and bottom waters balanced by mid-depth thermocline and near-surface waters. Balance estimations (Toole and Warren, 1993; Robbins and Toole, 1997; Stramma and Lutjeharms, 1997; Bryden and Beal, 2001) confirmed the Agulhas Current as the balancing agent of such northward flow, connecting it to the AMOC.

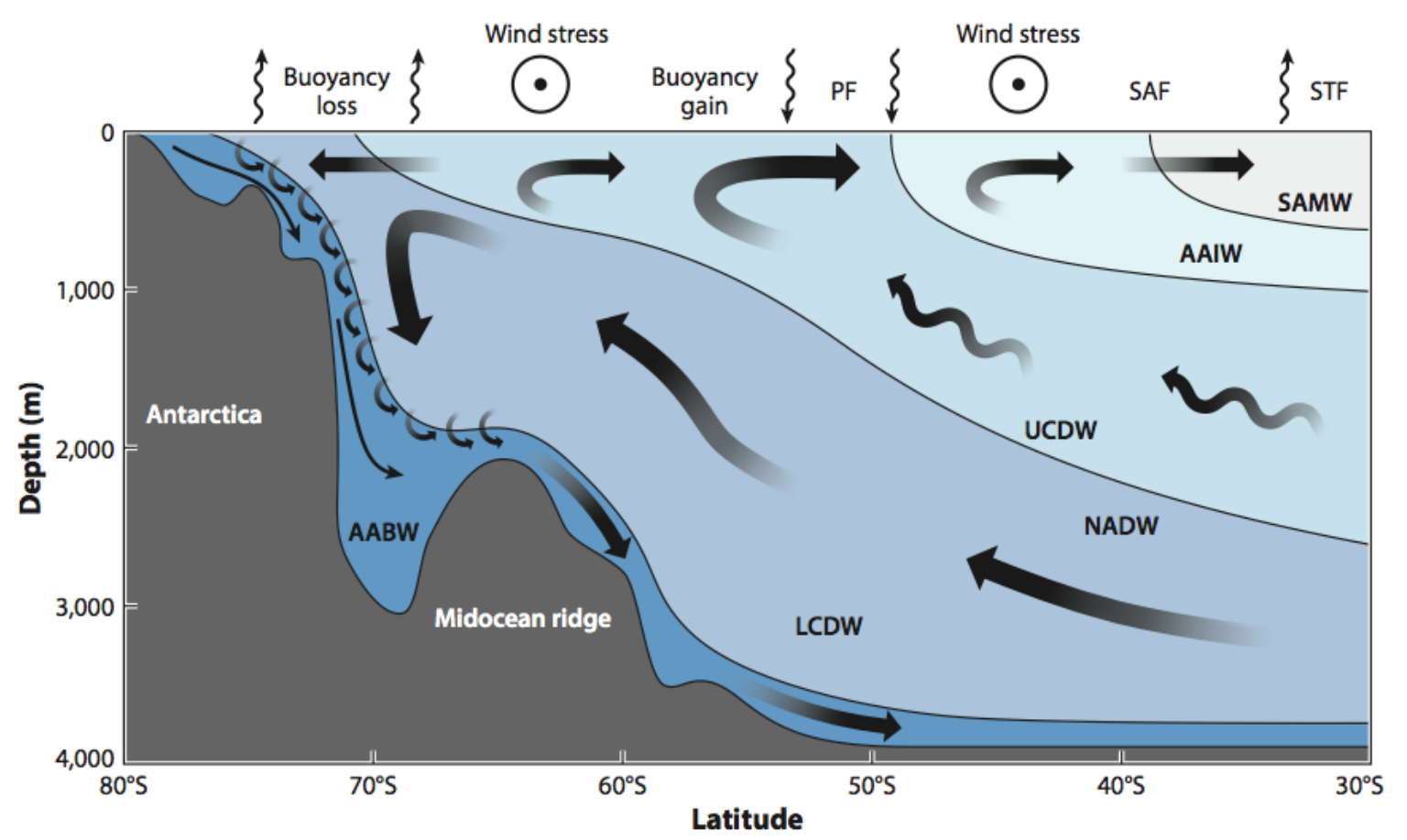

Figure 1.2: Southern Ocean Atlantic sector water mass structure and its associated fronts from Gent (2016). Abbreviations: AABW, Antarctic Bottom Water; LCDW, Lower Circumpolar Deep Water; NADW, North Atlantic Deep Water; UCDW, Upper Circumpolar Deep Water; AAIW, Antarctic Intermediate Water; SAMW, Subantarctic Mode Water; PF, Polar Front; SAF, Subantarctic Front; STF, Subtropical Front.

\section{Motivation}

The variability of the MOC has been extensively studied at different timescales (e.g., Rahmstorf, 1995; Knorr and Lohmann, 2003; Peeters et al., 2004; Zhang and Delworth, 2005; Stouffer et al., 2006; Knorr and Lohmann, 2007; Lynch-Stieglitz et al., 2007; Meinen et al., 2013) and changes in the AMOC have been linked to changes in the position of the WSC0 line in the Southeast Atlantic Ocean (Biastoch et al., 2009; Biastoch and Böning, 2013). This, in turn, would control the STF position (Peeters et al., 2004; Biastoch et al., 2009; Beal et al., 2011; Dencausse et al., 2011) and the strength of the Agulhas Leakage (Alory et al., 2007). 
While ACC fronts are believed to respond to changes in winds and heat fluxes combined (Böning et al., 2008; Kim and Orsi, 2014; Downes et al., 2015), Sverdrup theory combined with the fact that the STF was thought to act as the subtropical gyre southern boundary (Speich et al., 2007) suggest that this front should be directly related to the WSC0 line. Rouault et al. (2009) discuss that changes in the transition between the South Atlantic and the Indian Ocean are caused by shifts of the wind field over the Indian Ocean, possibly influencing the position of the ocean fronts. More recent work by Graham and Boer (2013) and Boer et al. (2013) raise the question whether the WSC0 is actually the main driving factor of the STF position. They suggest it is mainly controlled by interaction with topography, while wind stress curl would be more associated with the SAF position. This is further supported by the work of Durgadoo et al. (2013), which have not observed any response of the subtropical front to the zero wind stress curl line shift; they find that considerable changes in Agulhas Leakage happen when increasing WSC south of it.

As the main forcings of the Subtropical Front (especially at the transition between the Atlantic and Indian oceans) are not yet completely understood, an assessment of the STF and the overlying wind field variability, as well as temperature, salinity and velocity, might yield more information on how these fields interact with each other, if at all. Secondarily, the relationship between the SAF and the wind field should also be assessed in order to see how the WSC0 position could affect it. Thus, the main question to be answered in this study is "what controls the frontal position variability over the Agulhas region?", focusing on decadal to interdecadal timescales, as it is the time scale of our datasets. 


\section{Data and Methods}

\subsection{Datasets}

Three distinct ocean products are used:

First, the simulation results of the National Center for Atmospheric Research (NCAR) Community Earth System Model (CESM) ocean component for the twentieth century. It is based on the Parallel Ocean Program version 2 (POP2) of the Los Alamos National Laboratory (Smith et al., 2010). It is a coarse resolution global model under the hydrostatic and Boussinesq approximations with an implicit free-surface formulation. It uses a displaced North Pole grid with a horizontal nominal resolution of $1^{\circ}$, increasing meridionally up to $0.27^{\circ}$ near the equator. It has 60 vertical levels, which decrease in resolution from $10 \mathrm{~m}$ (surface to $160 \mathrm{~m}$ ) to $250 \mathrm{~m}$ (below $3500 \mathrm{~m}$ ).

The POP2 ocean-only component is forced by the Coordinated Ocean-ice Reference Experiments (CORE) version 2 (i.e., the version that includes interannual variability) dataset, which is described in Large and Yeager (2009). Although this is a coarse resolution model and does not allow eddies, it uses a parameterisation scheme (Gent and Mcwilliams, 1990) that was shown to be robust for very turbulent regions, such as the Southern Ocean (Gent, 2016). Its behaviour for the Southern Ocean (including our region of interest) was described in detail by Weijer et al. (2012). More details about this POP2 experiment, such as spin-up procedures and parameterisations, can be found in Danabasoglu et al. (2012).

Downes et al. (2015) have already conducted an intercomparison project using different models forced by CORE and concluded that the NCAR POP2 model is one of the best to represent the Southern Ocean. We use a second dataset, the World Ocean Atlas 2013 (WOA13, Locarnini et al., 2013; Zweng et al., 2013), for model validation of the temperature and salinity fields.

In order to be able to compare the velocity and sea surface height fields, we use a third dataset, the Ocean Reanalysis System 4 (ORAS4). It was developed by the European Centre for Medium-Range Weather Forecasts (ECMWF) in conjunction with other institutions and uses the NEMO ocean model and its assimilation system NEMOVAR on a 3D-Var FGAT configuration (Balmaseda et al., 2013). It assimilates temperature and salinity profiles from the EN3 dataset (Ingleby and Huddleston, 2007), as well as XBT, CTD, Argo and mooring data. The heat, momentum and freshwater fluxes used are obtained from the ERA-40 reanalysis (Kalnay et al., 1996) until 1989 and from the ERA-Interim project (Dee et al., 2011) from 1989 to 2009. Data from NCEP's Optimal Interpolation and OSTIA analysis are also assimilated from 2010 onwards (Mogensen et al., 2012). It has a $1^{\circ}$ by $1^{\circ}$ resolution and 42 vertical levels. Its time period spans from 1958 to 2011.

For our simple validation, we have focused on highlighting the regions of higher bias and checking if it represents properly the frontal structure of our region of study. Simple 
differences between those were calculated and temperature-salinity diagrams for specific points of interest were compared.

\subsection{Methods of Analysis}

\subsubsection{Front Identification}

The frontal system was first characterised by computing the mean-state of each variable used to identify ocean fronts, i.e., (a) temperature (from the surface to intermediate depth levels), (b) sea surface height, (c) upper layer current velocities. The fronts were identified according to the following criteria:

- location of sea surface temperature (SST) meridional gradient maxima on meridional transects;

- location of sea surface height (SSH) meridional gradient maxima on meridional transects;

- location of the surface zonal velocity maxima on meridional transects;

- the position of specific SSH contour labels selected based on the previous criteria;

- known features in the temperature and salinity transects that can be used to identify which specific front corresponds to the peaks found.

The analyses of temperature and salinity were extended from the surface to 2000 $\mathrm{m}$ on meridional transects at three given longitudes: $0^{\circ}, 20^{\circ} \mathrm{E}$ and $30^{\circ} \mathrm{E}$ as these allow a direct comparison to WOA13 and also yield information on these fronts positions at the transition between the Southeast Atlantic and the Indian oceans. Once each local maximum in temperature and surface height was related to its respective front, time series of each front's meridional position were calculated for all datasets based on the position of a specific contour. The choice of such contour was done based on which SSH value corresponded to each peak on a cross-section averaged between 20 and $30^{\circ} \mathrm{E}$. This "specific label approach" was already used for the Southeast Atlantic (Billany et al., 2010; Swart et al., 2010) and for other regions (Sokolov and Rintoul, 2007, 2009a; Kim and Orsi, 2014) and was proven to yield better results for tracking fronts in time than water mass properties and the meridional gradients themselves (Chapman, 2014). Although Graham et al. (2012) highlight that tracking fronts by meridional gradients may have certain advantages, Chapman (2014) shows that the contour method has limitations that could restrict its use only when using high-resolution products, which is not the case here.

\subsubsection{Comparison to the wind field}

Once identified, front positions were compared to the wind field through its wind stress curl (WSC), which was calculated as: 


$$
\nabla \times \tau=\frac{\partial \tau^{y}}{\partial x}-\frac{\partial \tau^{x}}{\partial y}
$$

$\tau$ being given by the following equation from Smith (1988):

$$
\tau=\rho_{\text {air }} C_{D} U_{10}^{2}
$$

where $\rho_{\text {air }}=1.2 \mathrm{~kg} \mathrm{~m}^{-3}$ is the air density, $C_{D}=1.2 \cdot 10^{-3}$ is the wind drag coefficient (Large and Pond, 1981) and $U_{10}$ is the wind velocity at $10 \mathrm{~m}$ above the surface. It is worth reminding that $\tau$ has the same unit as pressure (i.e., $\mathrm{Pa}$ or $\mathrm{Nm}^{-2}$ ), but WSC has units of $\mathrm{Nm}^{-3}$.

Meridional profile of winds at $10 \mathrm{~m}$ for the Atlantic (i.e., $40^{\circ} \mathrm{W}-20^{\circ} \mathrm{E}$ ) and the Indian Ocean $\left(50-100^{\circ} \mathrm{E}\right)$ were also used for discussion on changes over the wind field as well as meridional profiles of WSC, all presented as decadal means.

\subsubsection{Comparison to temperature and salinity changes}

Temperature and salinity changes were assessed through a temperature-salinity diagram, surface trends over the Agulhas and eventually vertical profiles of heat and salt fluxes towards the Atlantic. Fluxes were calculated through equations 3 and 4 respectively:

$$
\begin{gathered}
\text { H.Flux }=\int_{y_{a}}^{y_{b}} \rho_{0} c_{p} T \cdot U d y \\
\text { S.Flux }=\int_{y_{a}}^{y_{b}} \rho_{0} S \cdot U d y
\end{gathered}
$$

where $\rho_{0}=1027 \mathrm{~kg} \mathrm{~m}^{-3}$ is the density of sea water (here simplified as a constant value), $c_{p}=3850 \mathrm{Jkg}^{-1} \mathrm{~K}^{-1}$ is sea water's specific heat, $\mathrm{T}$ the temperature in Kelvin and $\mathrm{S}$ the salinity in $\mathrm{g} / \mathrm{kg}$. The integration was done transversal to the Agulhas Leakage ( $y_{a}$ and $y_{b}$ being its boundaries); associated current and fluxes vertical profiles were given respectively in Watts per meter $\left(W m^{-1}\right)$ and $\mathrm{kg} \mathrm{m}^{-1} \mathrm{~s}^{-1}$.

\subsubsection{Evaluation of the velocity fields}

The currents volume transport was calculated through the following integral:

$$
T=\int_{y_{a}}^{y_{b}} \int_{z_{b}}^{0} U d z d y
$$

where $\mathrm{U}$ is the velocity of the current, $y_{a}$ and $y_{b}$ the horizontal boundaries and $z_{b}=$ $1500 \mathrm{~m}$, as it was considered the maximum extent of the Agulhas current (and its leakageassociated current as well). Results are given in Sverdrups (Sv, which represents $10^{6}$ $\left.m^{3} s^{-1}\right)$. 
For the discussion of some of our results, eddy kinetic energy was calculated. Its formula, given by equation 6 , is based on fluctuations over the geostrophic velocity field, which is why we were able to calculate it even though the model does not allow eddies.

$$
E K E=\sqrt{\left[\left(u-u_{g}\right)^{2}+\left(v-v_{g}\right)^{2}\right]}
$$

where $u_{g}$ and $v_{g}$ are the geostrophic velocities calculated as

$$
\begin{gathered}
u_{g}=-\frac{1}{f} \frac{\partial \eta}{\partial y} \\
v_{g}=\frac{1}{f} \frac{\partial \eta}{\partial x}
\end{gathered}
$$

where $f$ is the Coriolis parameter (defined as $f=2 \Omega \sin (\varphi), \varphi$ being the latitude). Results for EKE were given either in $\mathrm{m}^{2} \mathrm{~s}^{-2}$ or $\mathrm{cm}^{2} \mathrm{~s}^{-2}$. Two different units were used to make numbers easier to read.

\subsubsection{Indices for gyre strength and extent}

Two indices were used for comparing front changes with changes over the circulation of the Indian and South Atlantic subtropical gyres: (a) an index for strength, or intensity, of the circulation. It was calculated as the average of the Barotropic Stream Function (BSF) inside the region where it was negative (i.e., inside the subtropical gyres) with its seasonal cycle removed. In order to filter out its high-frequency variability, a 12-month running mean was applied twice. (b) an index for its extent was calculated as the area where the BSF was negative. This was done by integrating over the area where BSF was negative and removing its seasonal cycle. As in (a), a double 12-month running mean filter was applied to reduce variability. The two indices were calculated for the IndianAtlantic Supergyre (i.e., from $60^{\circ} \mathrm{W}$ to $120^{\circ} \mathrm{E}$ ) and for both gyres separately (dividing them at $\left.20^{\circ} \mathrm{E}\right)$.

The position of the zero BSF contour (BSF0) was also used as an index for the position of the southern edge of the subtropical gyres, as this line represents where no meridional barotropic transport occurs.

\subsubsection{Other Statistics}

Since the model used has a coarse horizontal resolution $\left(1^{\circ}\right.$ by $\left.1^{\circ}\right)$, the position of a specific contour label (e.g., the position of fronts, WSC0 and BSF0) at each step of the time series had their value found through a linear interpolation between the two existing values on the surrounding grid points. For correlations (including for cross-correlations), the Pearson correlation was used. All time series had their seasonal cycles and trends removed before calculating correlations and all results presented in this work are significant at $95 \%$ or higher. 


\section{Model Validation}

\subsection{Description of the climate-mean fields}

Overall, all three datasets show a similar SST structure (Fig.4.1a-c): warmer surface waters towards the equator and colder surface waters towards higher latitudes. It is possible to see that the southwestern Indian Ocean is warmer than the southeastern Atlantic. The center of the South Atlantic Subtropical gyre can also be identified by the pool of warmest temperatures close to $20^{\circ} \mathrm{S}$ and $40^{\circ} \mathrm{W}$ (the upper left edge of all plots). Differences are shown in Fig.4.1d,e. The warm water tongue coming from the Agulhas Current towards the Atlantic is farthest from $20^{\circ} \mathrm{E}$ on WOA13 than on the other two datasets.

The surface salinity fields (Fig.4.2a-c) are not as similar as the surface temperature ones. POP2 does not represent it so well, showing lower values throughout the entire region south of $40^{\circ} \mathrm{S}$ and a tongue of fresher water west of Greenwich until about $30^{\circ} \mathrm{S}$ (Fig.4.2d,e). The eastern edge of the Atlantic basin also shows higher salinity values than ORAS4 and WOA13, as does the southwestern Indian Ocean. Despite those differences, the overall pattern is represented by the model. Highest salinity waters are found closer to the center of the Atlantic Subtropical Gyre and fresher waters are found over the Southern Ocean.

As WOA13 does not have velocity fields, model results are compared to the ORAS4 reanalysis only. The sea surface height (SSH) structure is shown in Fig.4.3 and is in good agreement with ORAS4. The main difference (Fig.4.3c) is an overall overestimated SSH, which is more pronounced at the Southwestern Indian and the Southern Ocean.

As for the surface zonal velocity field (Fig.4.4), POP2 has a similar structure to ORAS4, yet about $0.1 \mathrm{~m} / \mathrm{s}$ more intense (reaching up to $0.2 \mathrm{~m} / \mathrm{s}$ right south of Africa). The stronger velocities can be explained by the also stronger meridional SSH gradient field (Fig.4.5d,e) which, although very similar (even more so at the eastern side of the Atlantic basin), is up to $0.02 \mathrm{~m} / 100 \mathrm{~km}$ stronger in POP2. This intensity difference, however, is not as pronounced on the meridional temperature gradient field (Fig.4.5a-c), which once again bears a better resemblance at the eastern side of the basin and overall has a pattern more similar to the ORAS4 product than to WOA13.

The mean meridional sections of temperature and salinity at the longitudes of $0^{\circ}$, $20^{\circ} \mathrm{E}$ and $30^{\circ} \mathrm{E}$ (Figs. 4.6, 4.7 and 4.8 respectively) show that the POP2 model is able to reproduce the features first used by Orsi et al. (1995) to identify the Southern Ocean fronts. (i) The salinity minimum tongue responsible for the AAIW formation - used to identify the STF (which lies above it to the north) and the SAF (which lies where this fresher water sinks); (ii) The subsurface temperature minimum used to identify the PF, which lies north of it. They can be identified by the strong vertical tilt and sometimes outcrop of the temperature and salinity isolines located at the regions mentioned above (tilted isolines reach from 400 to $1000 \mathrm{~m}$, sometimes even deeper depending on the longitude). 

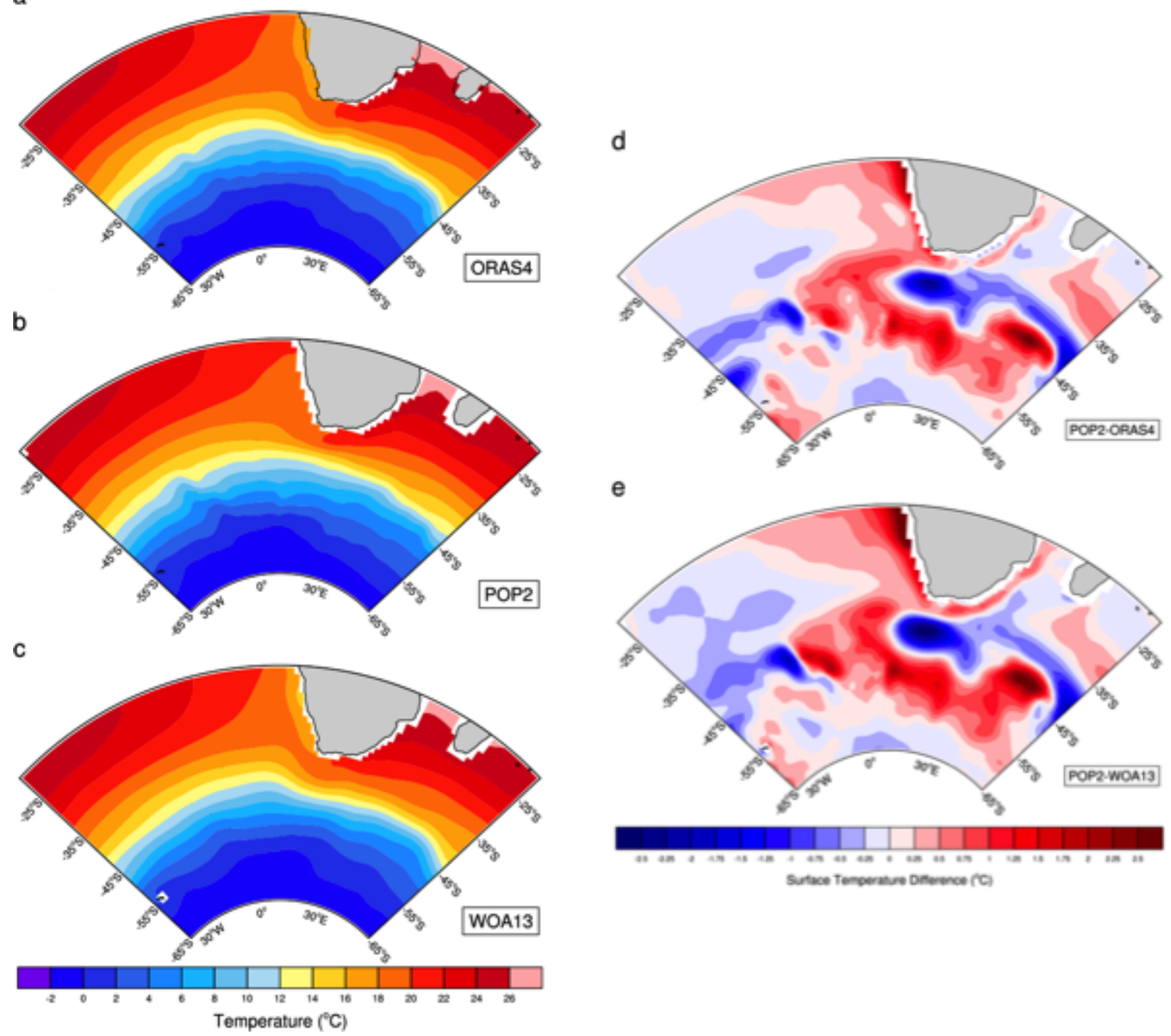

Figure 4.1: (a-c) Mean sea surface temperature fields from (a) ORAS4; (b) POP2; (c) WOA13. (d, e) Difference between POP2 and (d) ORAS4; (e) WOA13.

It is important to notice, however, that in our datasets the features used to identify the SAF and the PF yield roughly the same position. This happens because, in this region, they are not separated enough for a coarse model resolution to distinguish them.

\subsection{Model biases relative to WOA13 and ORAS4}

The POP2 model results show strong biases at the regions of highest gradients (mainly the STF, SAF and Weddell Sea regions) and in the centre of the Atlantic basin (Fig.4.1d,e). As for salinity, significant biases were identified at the African coast and over the southwestern Indian Ocean (where it is overestimated). At the western region of our domain and between 35 and $40^{\circ} \mathrm{S}$, it is underestimated (Fig.4.2d,e) due to the low salinity tongue seen in the mean field. These biases, however, are not vertically homogeneous. An analysis 


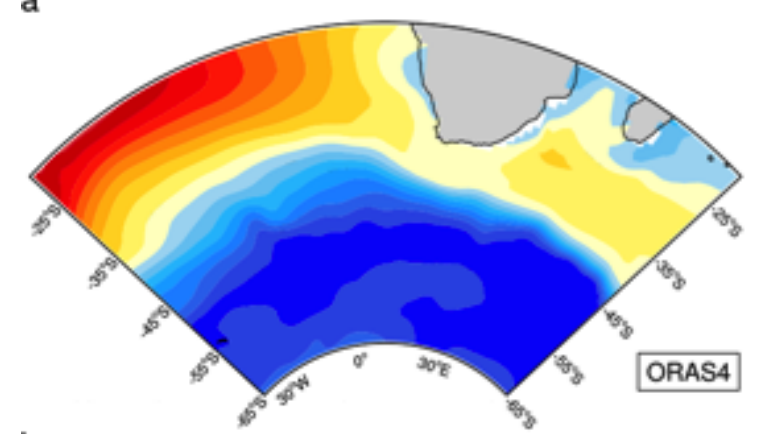

b

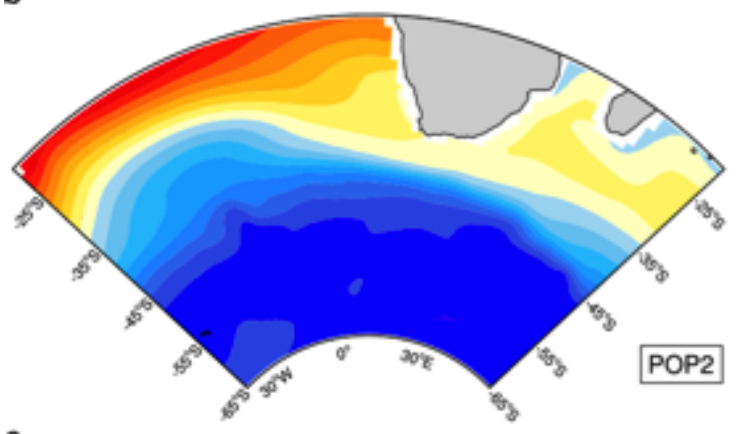

C

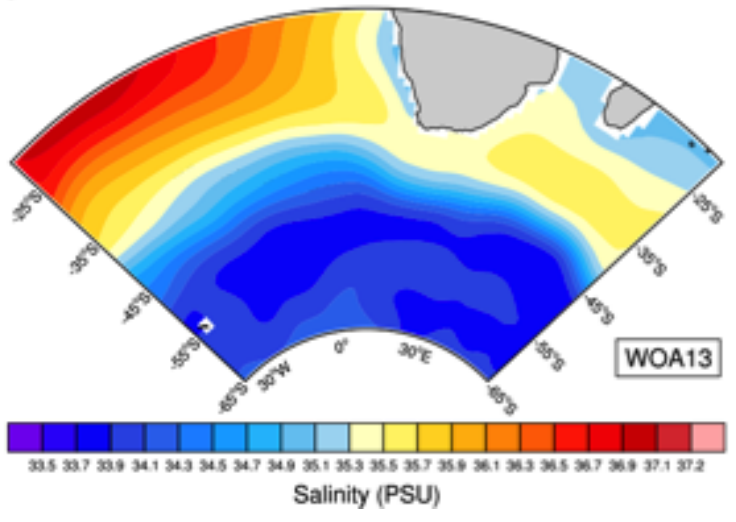

d

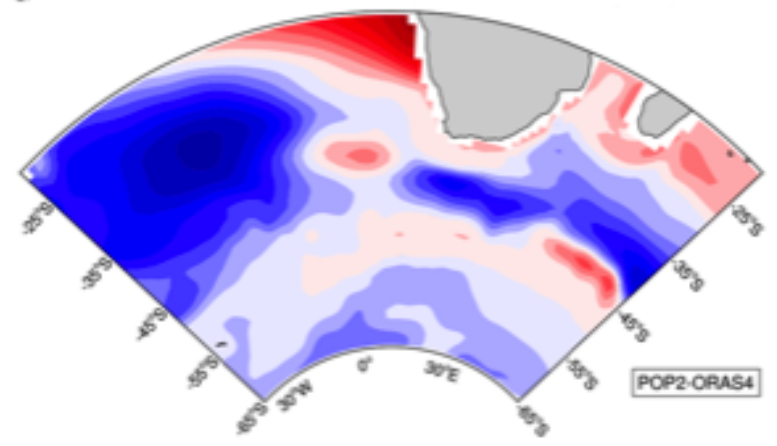

e

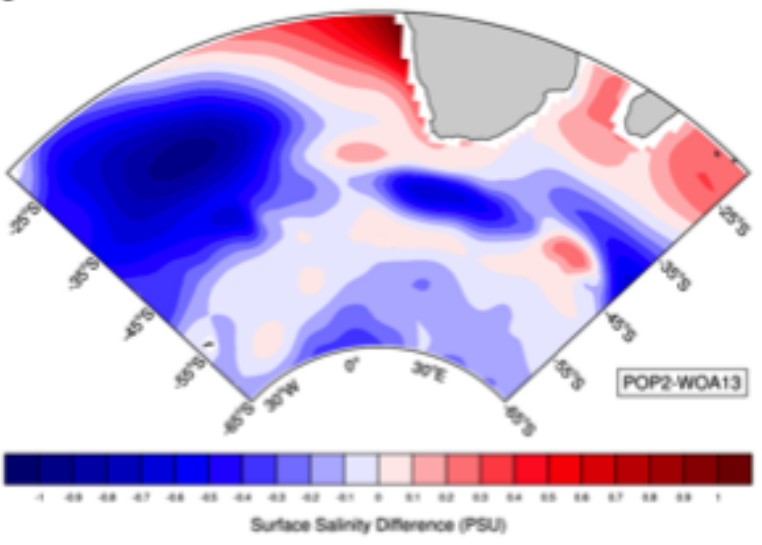

Figure 4.2: (a-c) Mean sea surface salinity fields from (a) ORAS4; (b) POP2; (c) WOA13. (d, e) Difference between POP2 and (d) ORAS4; (e) WOA13.

of the mean field difference at the 200, 300 and 900-meter levels (Figs. 7.1 and 7.2; supplementary material) shows that the model is progressively warmer and saltier, with higher salinity and temperature values than the reference at $900 \mathrm{~m}$.

The surface height field is overestimated throughout most of the South Atlantic except for the Agulhas Current southeast of Africa (where it is underestimated) and south of the Agulhas Leakage region (which is close to the reference; Fig.4.3c). The zonal velocity field difference (Fig.4.4c) shows that indeed the model has more zonally intense and narrower current jets than ORAS4, which partly explains the overestimated Agulhas Current transport. It is worth mentioning that leakage, due to the coarse model resolution, is represented as a viscous boundary layer current (Weijer et al., 2012). It is expected, therefore, that smaller scale eddy-related processes are not well represented and that transports are overestimated as discussed in Weijer et al. (2012). Most strong biases are 

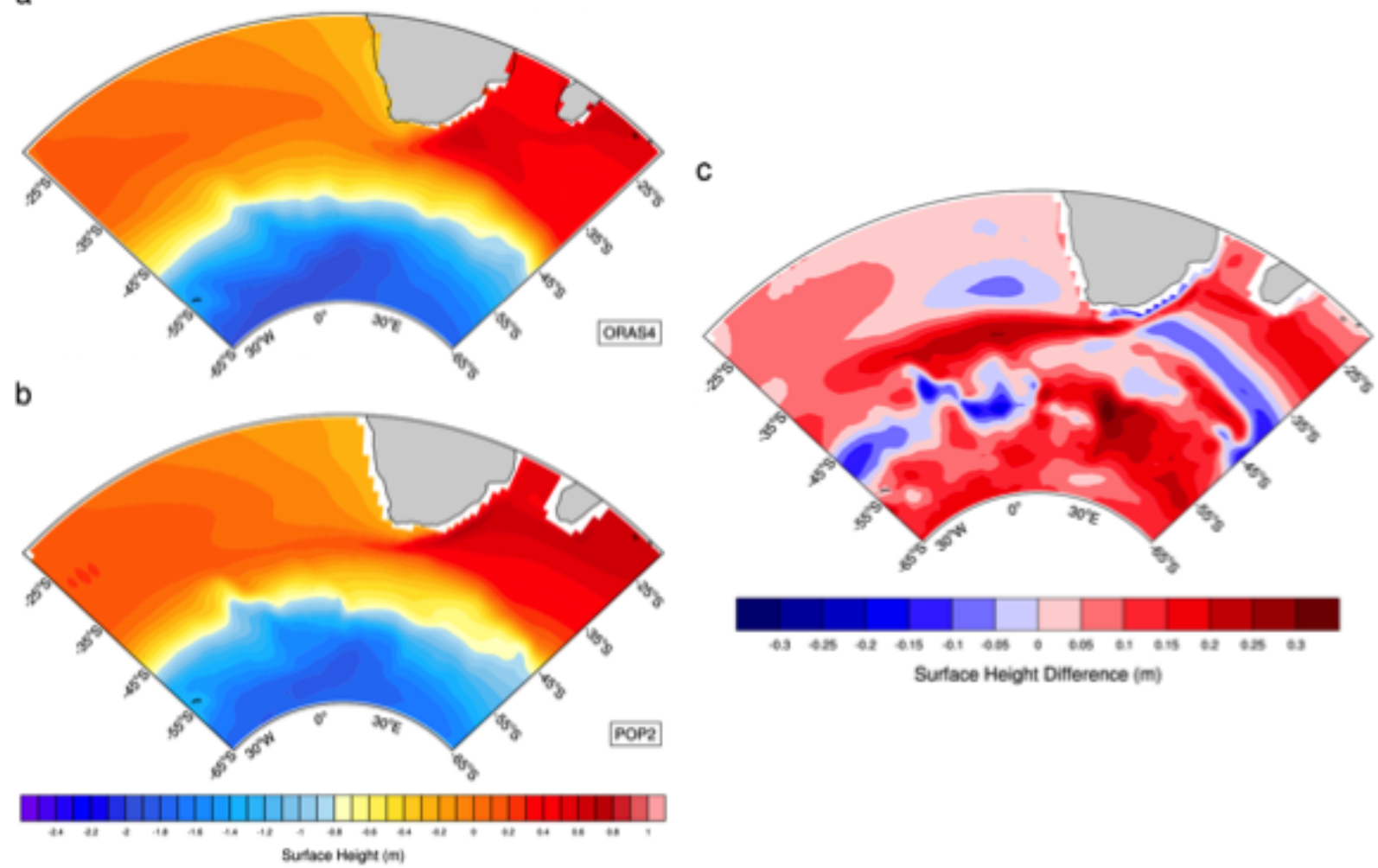

Figure 4.3: (a,b) Mean sea surface height fields from (a) ORAS4; (b) POP2 and (c) the difference between POP2 and ORAS4.

found where standard deviation is highest (Figs. 7.3 and 7.4; supplementary material).

A comparison of the meridional sections for the longitudes of $0^{\circ}, 20^{\circ} \mathrm{E}$ and $30^{\circ} \mathrm{E}$ (Figs. 4.6, 4.7 and 4.8 respectively) shows that the low salinity tongue corresponding to the AAIW at the eastern side of the basin is colder and fresher in the model, with increased biases to the east. The warmer surface temperature region in Greenwich spans from 58 to $30^{\circ} \mathrm{S}$ (Fig.4.6) and it is reduced to a region between 58 and $48^{\circ} \mathrm{S}$ at $30^{\circ} \mathrm{E}$ (Fig.4.8). The higher temperature and salinity values (compared to both ORAS4 and WOA13) at Greenwich become less intense at $20^{\circ} \mathrm{E}$ (Fig.4.7). The model is generally colder and fresher throughout the water column at $30^{\circ} \mathrm{E}$ (Fig.4.8). 


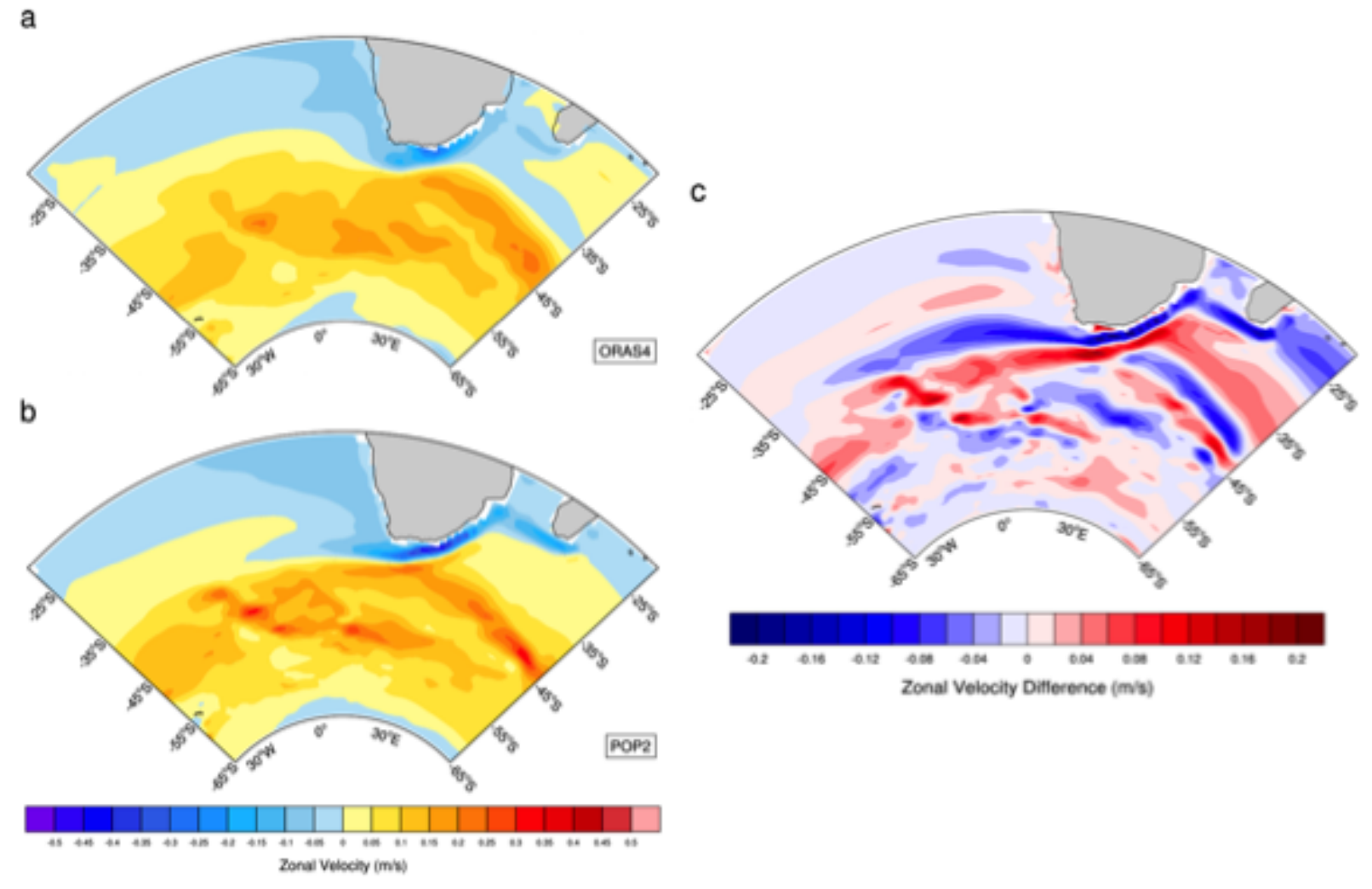

Figure 4.4: Mean surface zonal velocities fields from (a) ORAS4; (b) POP2 and (c) the difference between POP2 and ORAS4.

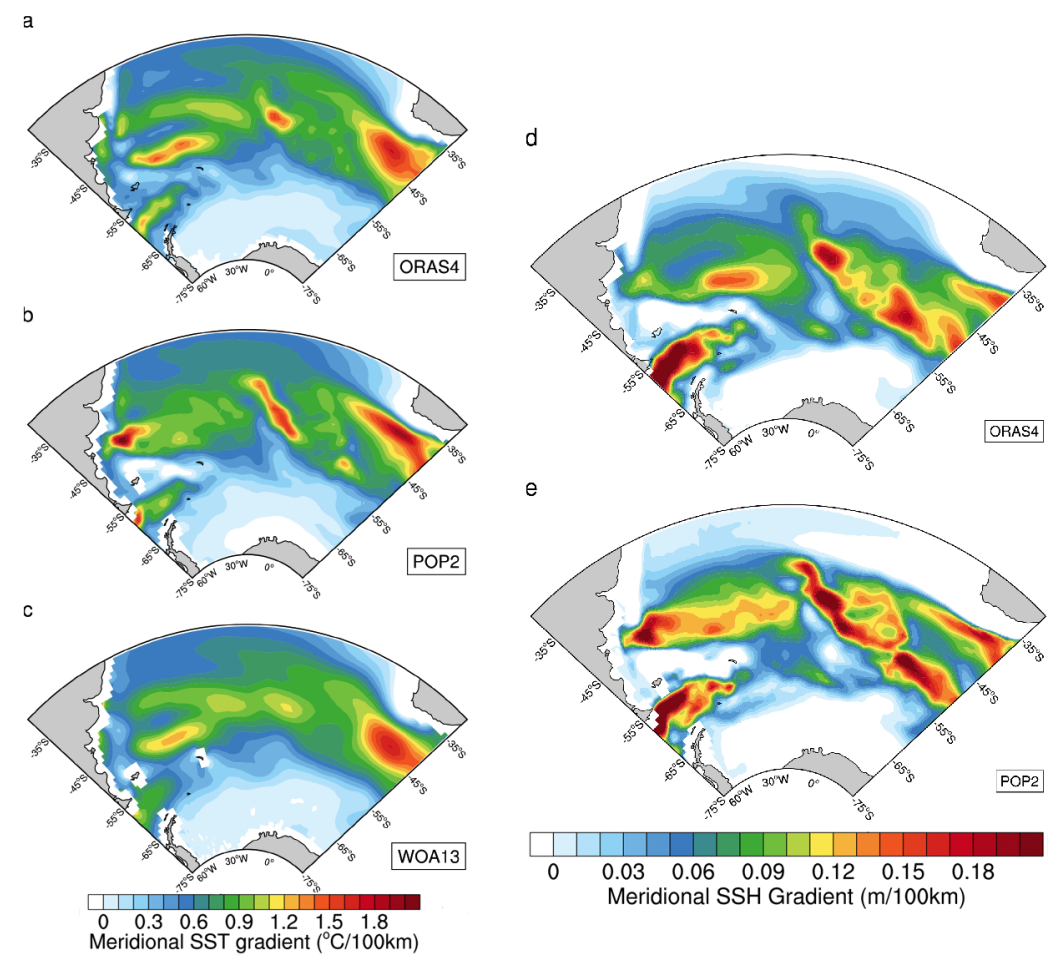

Figure 4.5: Mean meridional SST gradient fields from (a) ORAS4; (b) POP2; (c) WOA13; (d, e) mean meridional SSH gradients from ORAS4 and POP2. 


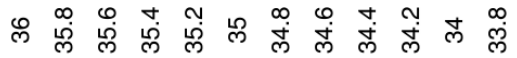

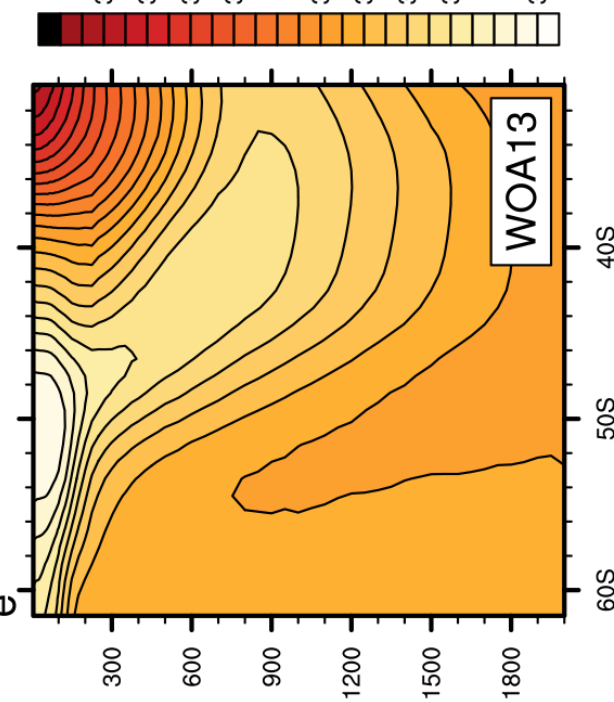

(u) 41dəp

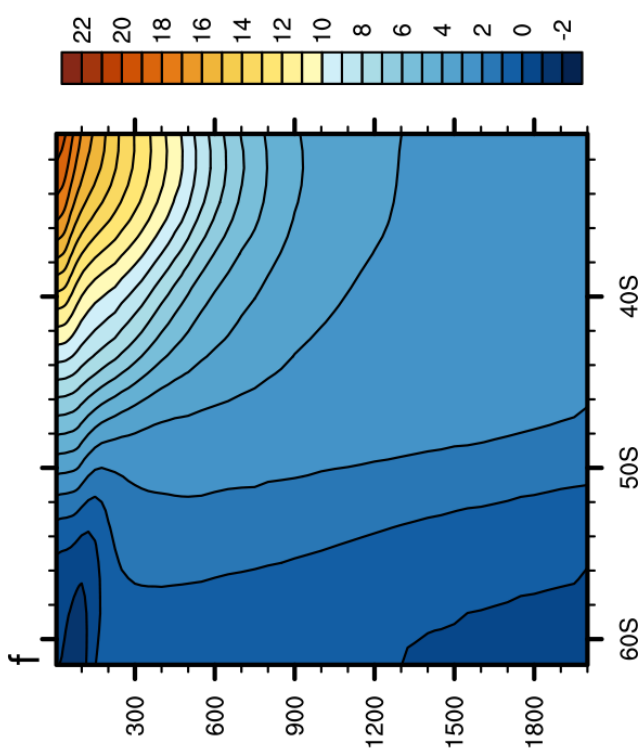

0
0
0
0
0
0
0
01
0
0
0
0
0
0
0
0
0
0
0
0
0
0
0
0
0
0
0
0
0
0
0
0
0
0

అ

(u) чldəp

ล ำ

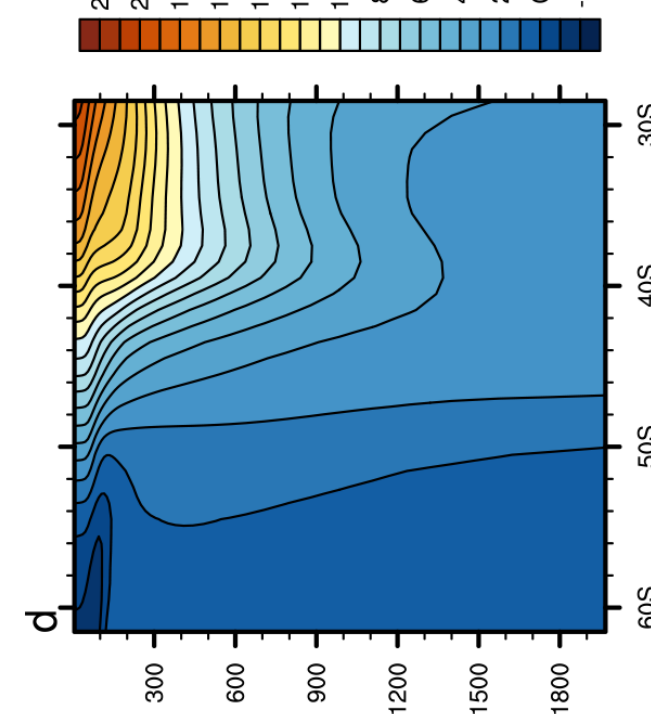

3
0
0
0
0
0
0
0
0
0
0
0
0
0
0
0
0
0
0
0

ঃ \& \& \&

(u) पldəp

(u) पldəp

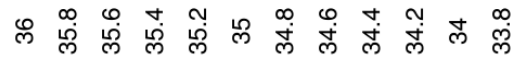

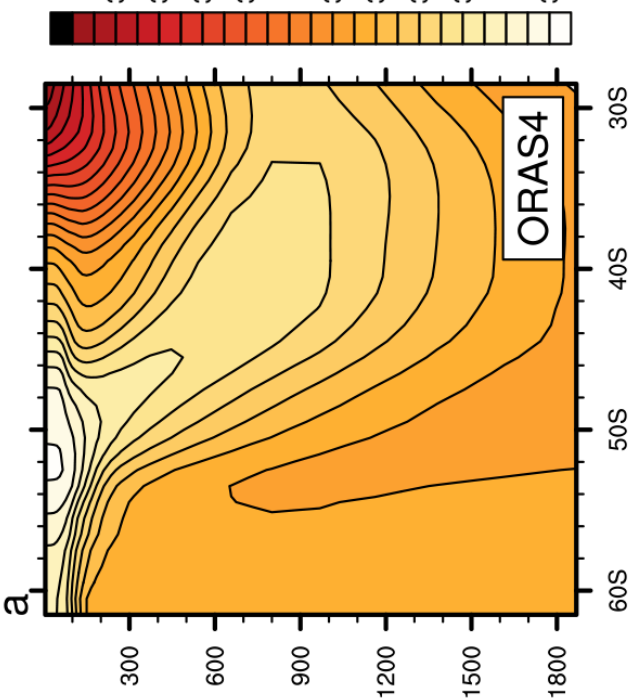

(u) पldəp

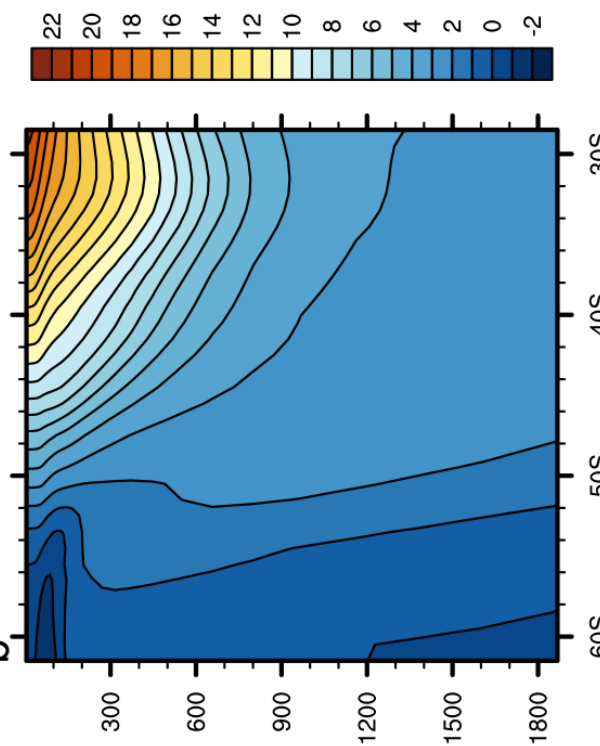

(w) पldəp

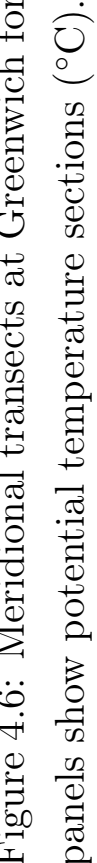




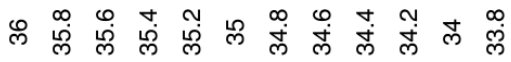

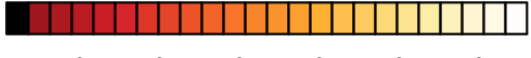

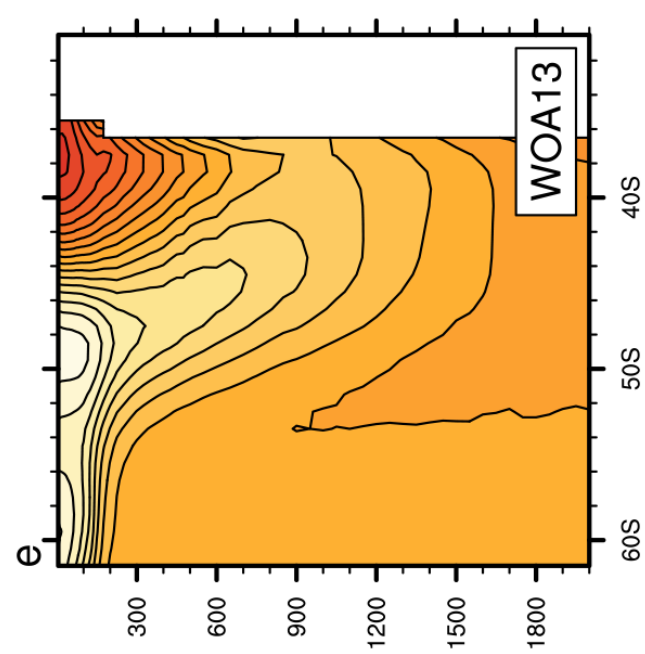

(u) uldəp

œ

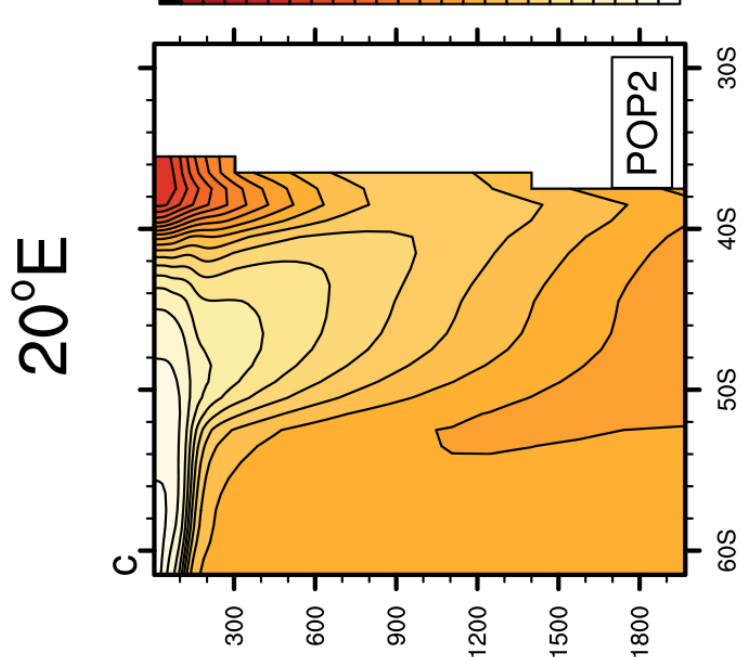

(u) पldəp

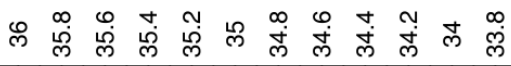

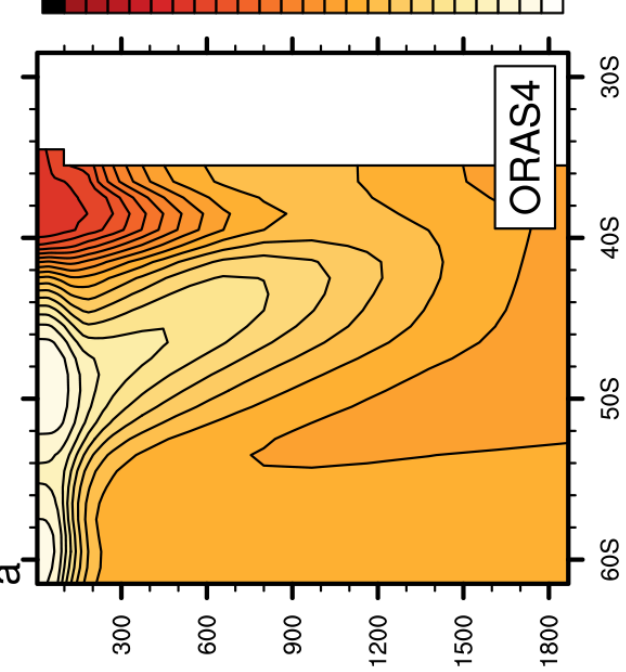

(u) पıdəp
ก

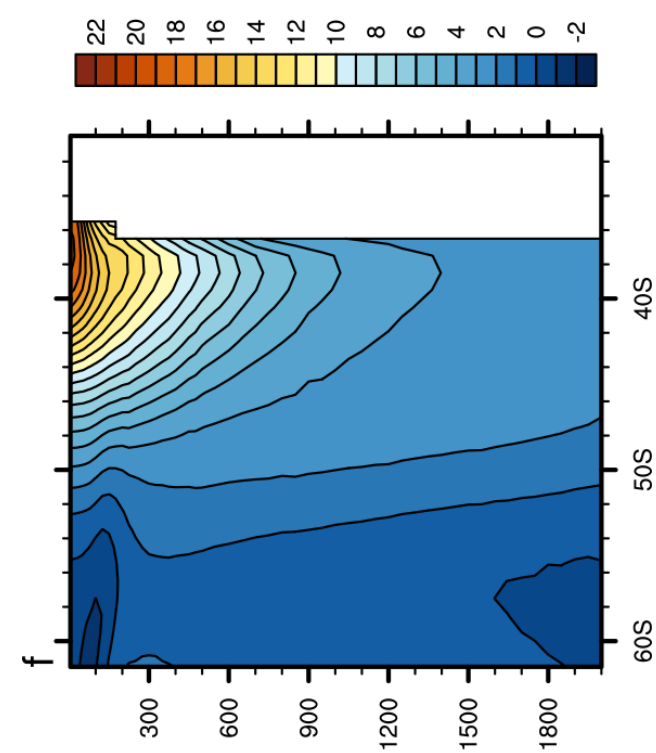

(w) पıdəp

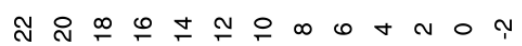

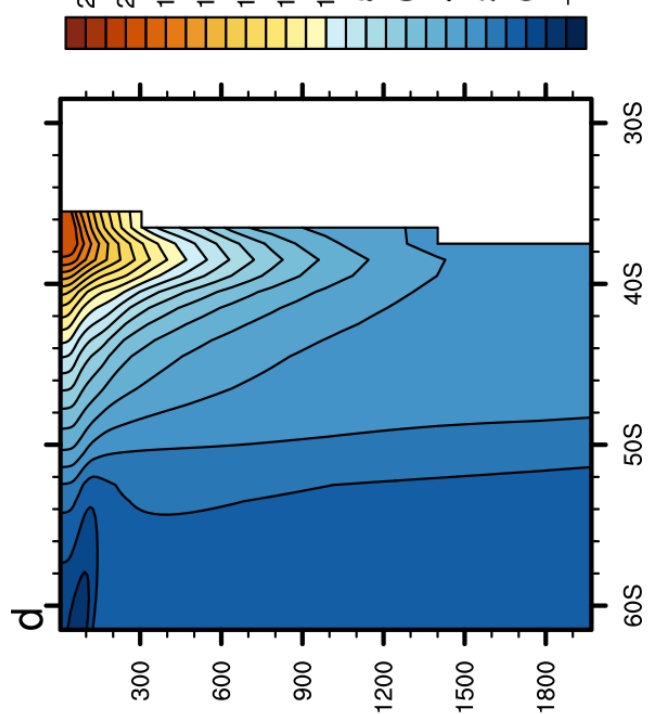

(u) प1dәp

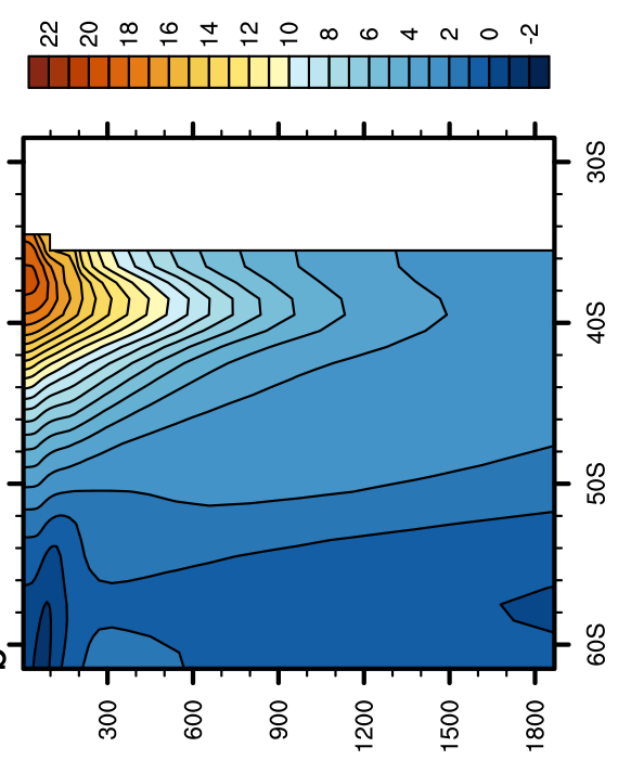

(u) प1dәp

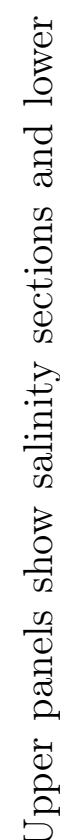

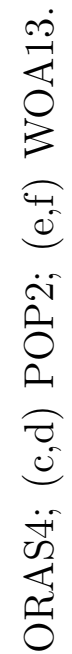

2

बृ

oี 0

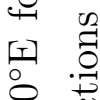

ᄋั

$+$

更 


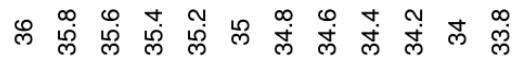

ก ก

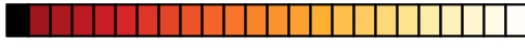

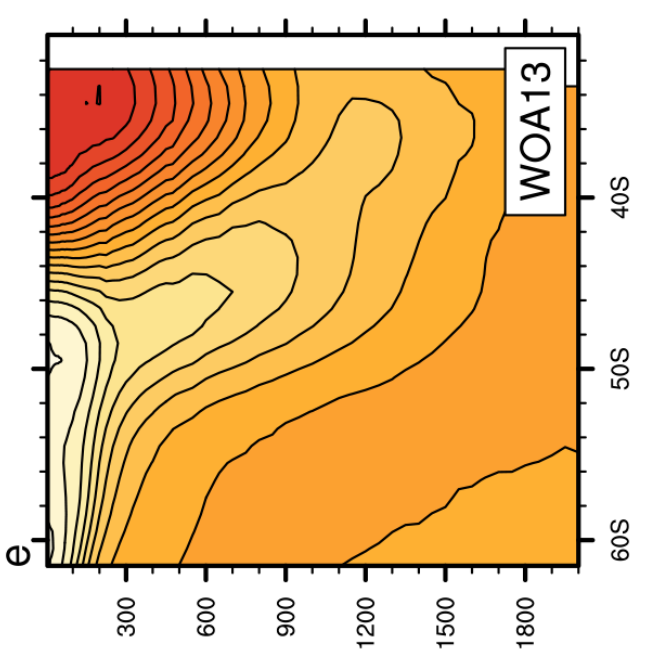

(u) पldəp

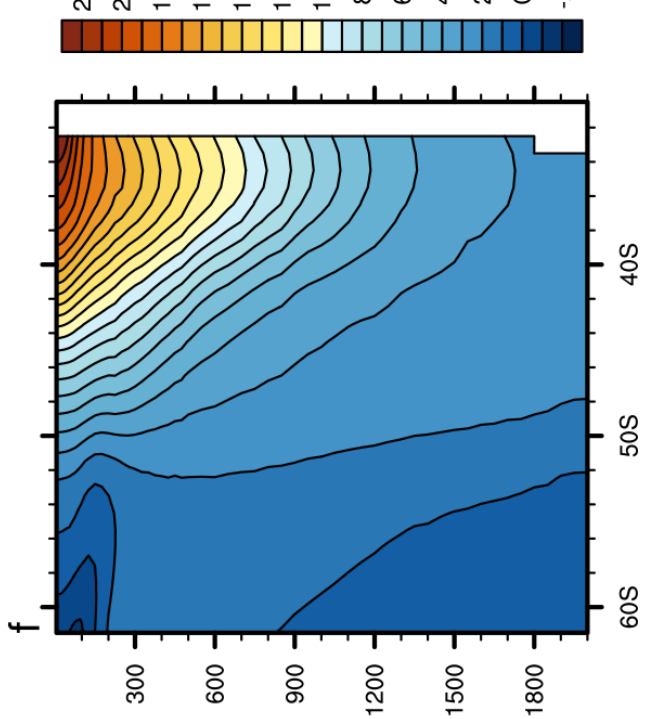

(w) uldəp

สำ

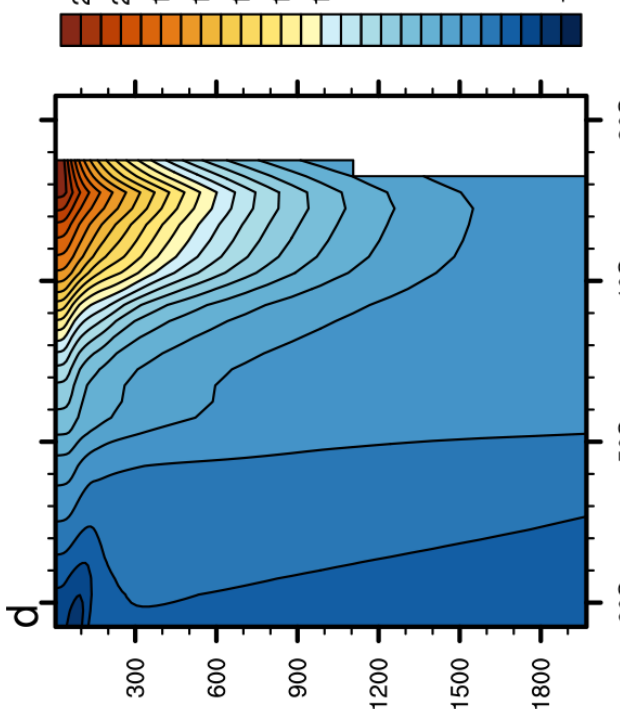

(u) чұdəp

สำก

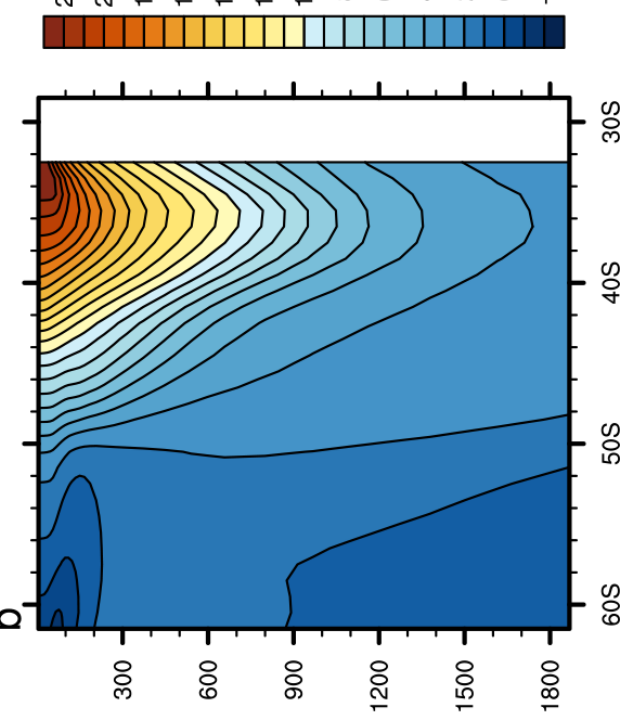

(u) чұdәp

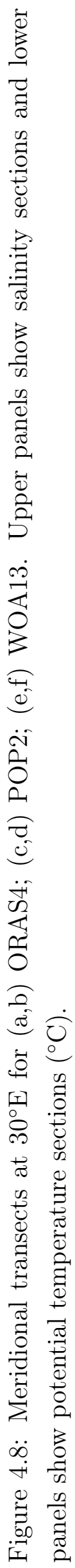




\subsection{Potential Temperature-Salinity diagrams}

The Potential Temperature-Salinity $(\theta-\mathrm{S})$ diagrams for the three datasets between 35 and $65^{\circ} \mathrm{S}$ (Fig.4.9) show that the Southern Ocean mean water mass structure is reasonably captured by the model. POP2 overall shows less dense and warmer surface waters than ORAS4 and WOA13 and a less saline Winter Water when compared to ORAS4 and the profiles shown by Talley et al. (2011) (Chapter 13, Figs. 13.7 and 13.13, hereafter T13; the figure shows three profiles over the 0 and $1^{\circ} \mathrm{E}$ at $39^{\circ} \mathrm{S}$ [red], $48^{\circ} \mathrm{S}$ [blue] and $61^{\circ} \mathrm{S}$ [magenta]; a copy of both figures is available in the supplementary material as Figs 7.5 and 7.6). The reason why WOA13 are warmer than the other two datasets is probably its summer bias due to the reduced number of winter observations available (?).

A comparison with the $\theta$-S Diagrams on T13 shows that none of the datasets used here could reproduce the frontal structure through $\theta$-S profiles as shown by the cruise data. A direct comparison of single profiles at the same locations (Fig.4.10) shows a much better agreement. The POP2 representation of the Winter Water is fresher and colder, while its versions of AAIW and Subantarctic Surface Water are considerably different from the observed, showing higher salinity (the salinity minimum is not as pronounced in the POP2 profile). The Upper Circumpolar Deep Water is also not well represented by the model, as it seems to be warmer and saltier, with a narrower salinity range than ORAS4 and T13 cruise data. The Lower Circumpolar Deep Water, however, is found in both POP2 and ORAS4 at very close values, comparable to T13 (less than 0.05 difference in salinity and less than $0.2^{\circ} \mathrm{C}$ in temperature). The Antarctic Bottom Water is warmer than $\mathrm{T} 13$ data in both datasets (about $0.1^{\circ} \mathrm{C}$ warmer), but ORAS4 shows closer values for salinity than POP2 does (about 34.65 for ORAS4 and T13, compared to 34.75 for POP2). The ORAS4 reanalysis, on the other hand, shows a structure strikingly similar to T13 at intermediate to greater depths. It shows large differences only closer to the surface, where it is over $1^{\circ} \mathrm{C}$ colder than the profiles shown in T13. Still, it is important to highlight that Fig.4.10 shows mean profiles for the 1970-2009 period, whereas T13 profiles were obtained from a specific cruise in October 1983. This might explain part of the discrepancies found. In order to facilitate further discussions and descriptions, we will keep the classical nomenclature of water masses throughout this study despite model results showing different temperature and salinity intervals for these water masses.

\subsection{Meridional Gradients}

The meridional gradient profiles (Fig.4.11) show that, except for the Greenwich SSH, the model represents satisfactorily the structure and position of the peaks present in both ORAS4 and WOA13 (although not with the same intensity), with a maximum difference in position of up to $1^{\circ}$ in latitude. As all products have a $1^{\circ}$ horizontal resolution, it means that they are at most a single grid point apart. Furthermore, it is possible to clearly identify two distinct fronts through $\mathrm{SSH}$ at 20 and $30^{\circ} \mathrm{E}$ with a maximum in SST 
gradient slightly north of the northernmost SSH gradient maximum. This is confirmed by the meridional SST and SSH gradient fields (Fig.4.5), which show that the POP2 model captures the frontal structure very well, especially at the Southeast Atlantic (the focus of this investigation). Also, these peaks coincide with the gradients found in the $0^{\circ}, 20^{\circ} \mathrm{E}$ and $30^{\circ} \mathrm{E}$ cross-sections (Figs. 4.6, 4.7 and 4.8 respectively), proving them to be robust from the surface to intermediate depths.
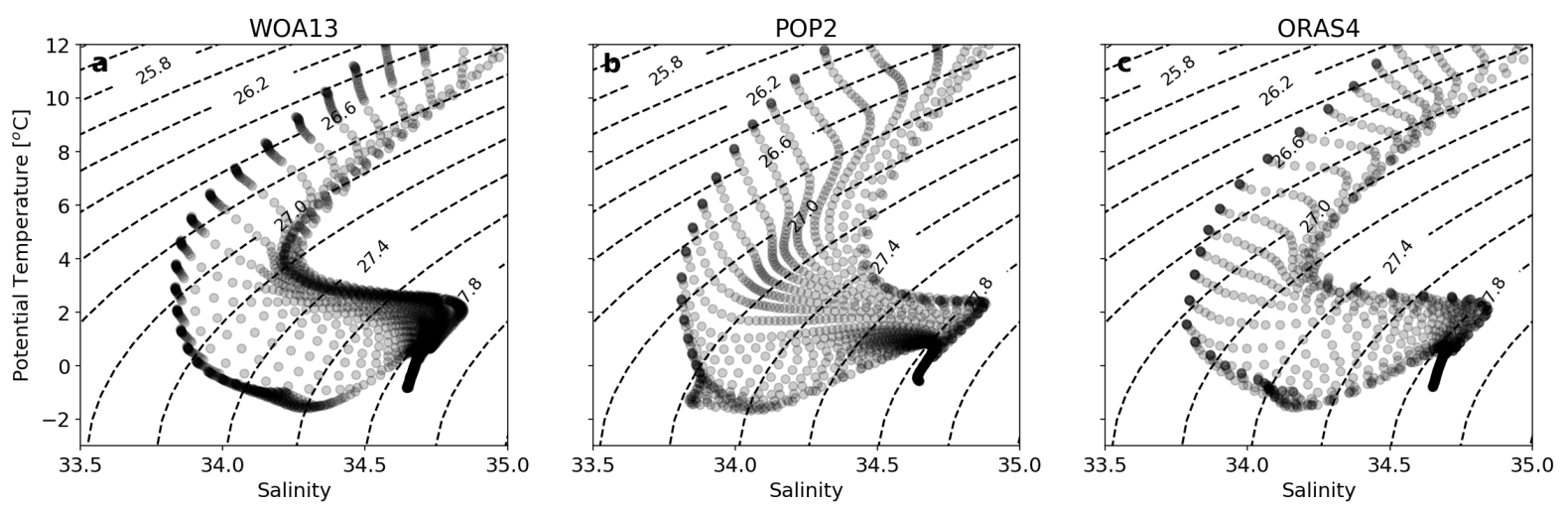

Figure 4.9: $\theta$-S diagrams at Greenwich $\left(0^{\circ}\right)$ from 35 to $65^{\circ} \mathrm{S}$ for (a) WOA13; (b) POP2; (c)ORAS4. 

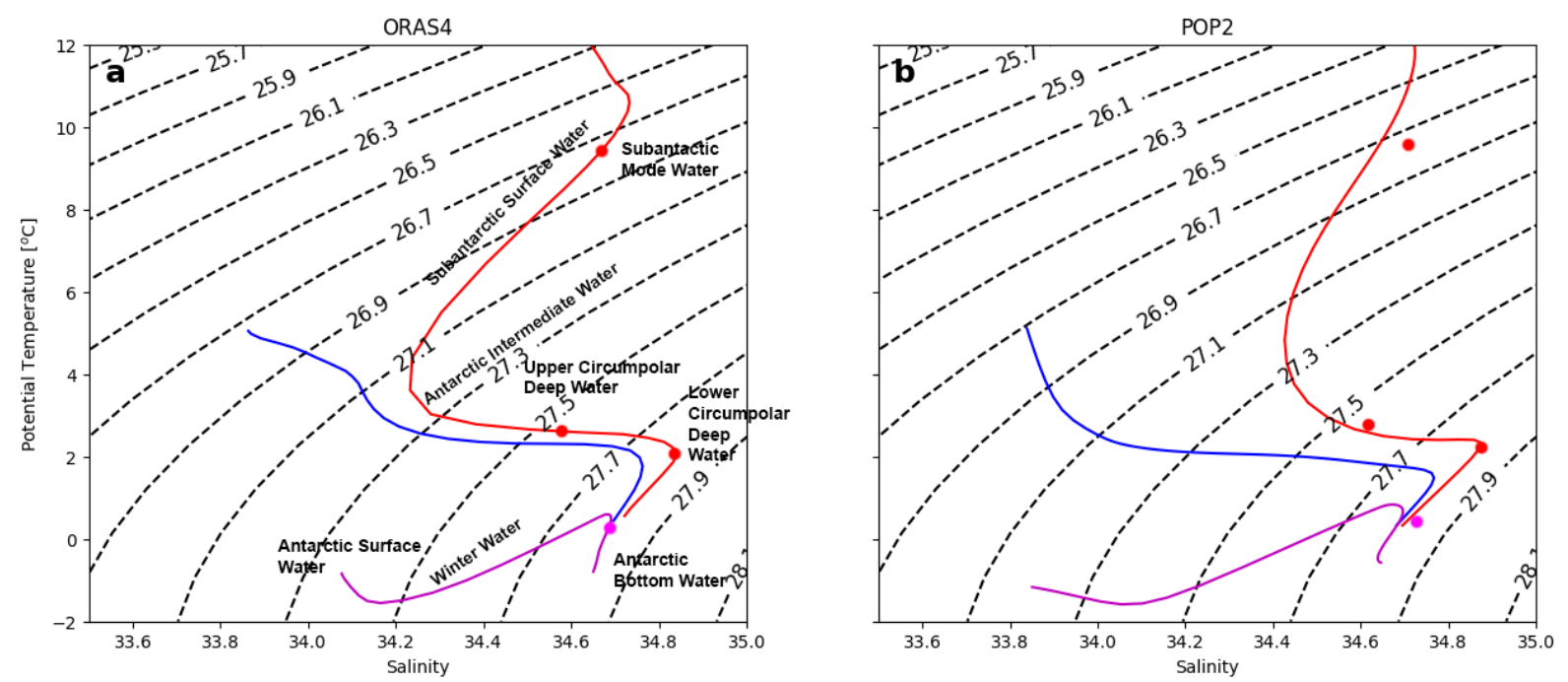

Figure 4.10: $\theta$-S diagrams for (a) ORAS4; (b) POP2 as in Fig. 13.13 of Talley et al. (2011). (Red) Subantarctic Zone profile at $39^{\circ} \mathrm{S}, 0^{\circ} \mathrm{E}$; (Blue) Polar Frontal Zone profile at $48^{\circ} \mathrm{S}, 1^{\circ} \mathrm{E}$; (Magenta) Antarctic Zone profile at $61^{\circ} \mathrm{S}, 1^{\circ} \mathrm{E}$. Also shown on panel (a) are the different water masses found at each profile. Water mass names were omitted from panel (b) for a better visualisation of the profiles. Red dots are shown as a reference for an easier comparison between the water types on both figures.
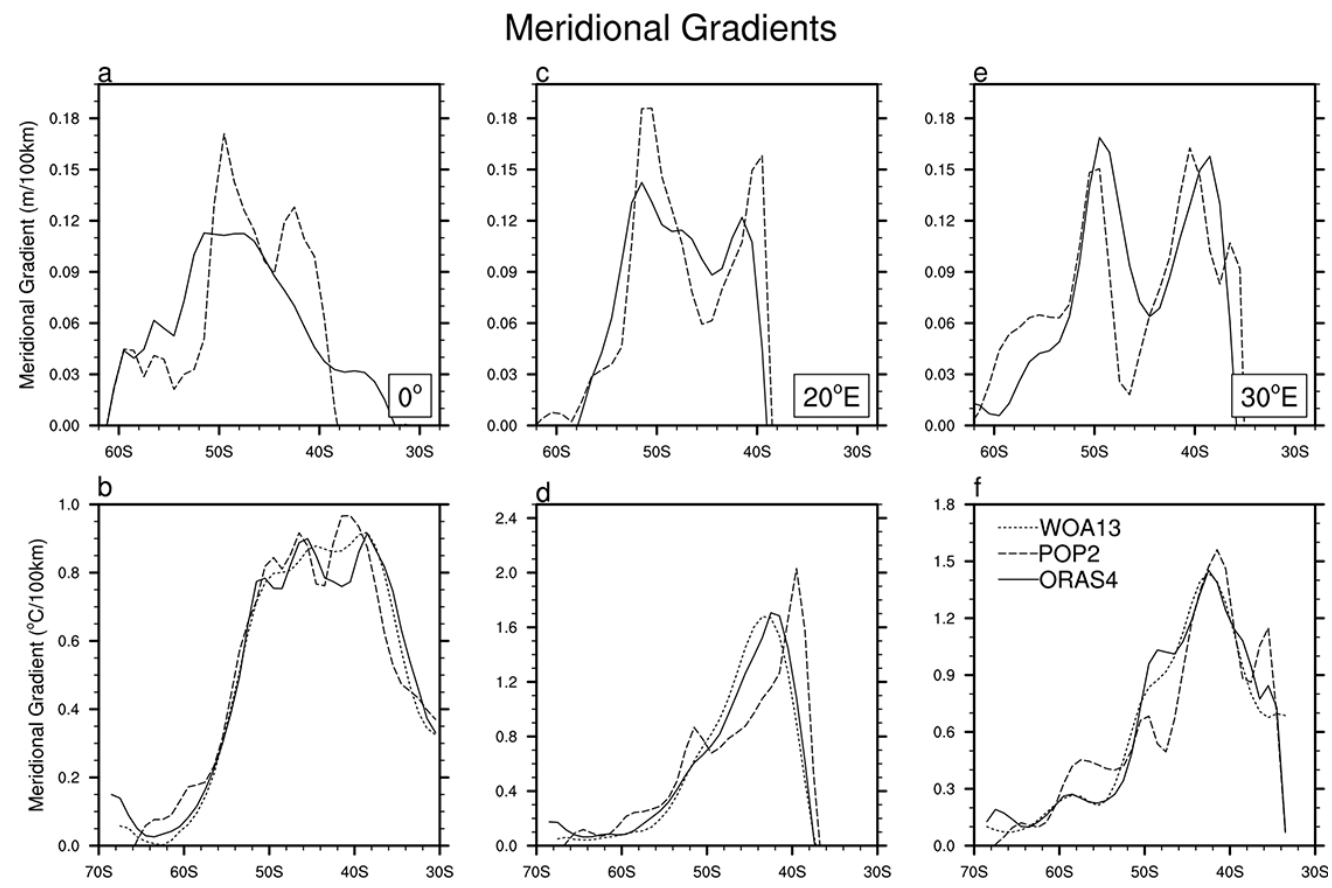

Figure 4.11: Meridional (upper) SSH and (lower) SST gradients for (solid lines) ORAS4; (dashed lines) POP2; (dotted lines) WOA13. panels (a,b) show gradients at Greenwich, $(\mathrm{c}, \mathrm{d})$ at $20^{\circ} \mathrm{E}$ and $(\mathrm{e}, \mathrm{f})$ at $30^{\circ} \mathrm{E}$. 


\section{Results and Discussion}

\subsection{Ocean Fronts Identification}

Identifying fronts through changes in temperature and salinity inside a certain interval such as the ones identified by Orsi et al. (1995) cannot be done due to the model biases. For the same reason, it is difficult to compare results to other studies in terms of values. Thus, we have focused on the spatial structures found in the temperature and salinity transects rather than the expected intervals. Fig. 5.1 summarises the comparison between POP2 and ORAS4 surface gradients and how they relate to the water properties vertical structure as well as the SSH values. This helps to identify fronts according to their mean position and thermohaline criteria. By comparing SSH values from both datasets, it is possible to see that POP2 is able to reproduce satisfactorily the mean state of the frontal structure and its meridional gradients at the same latitude, despite the differences in the $\mathrm{SSH}$ values themselves.

\section{Southeast Atlantic Fronts}
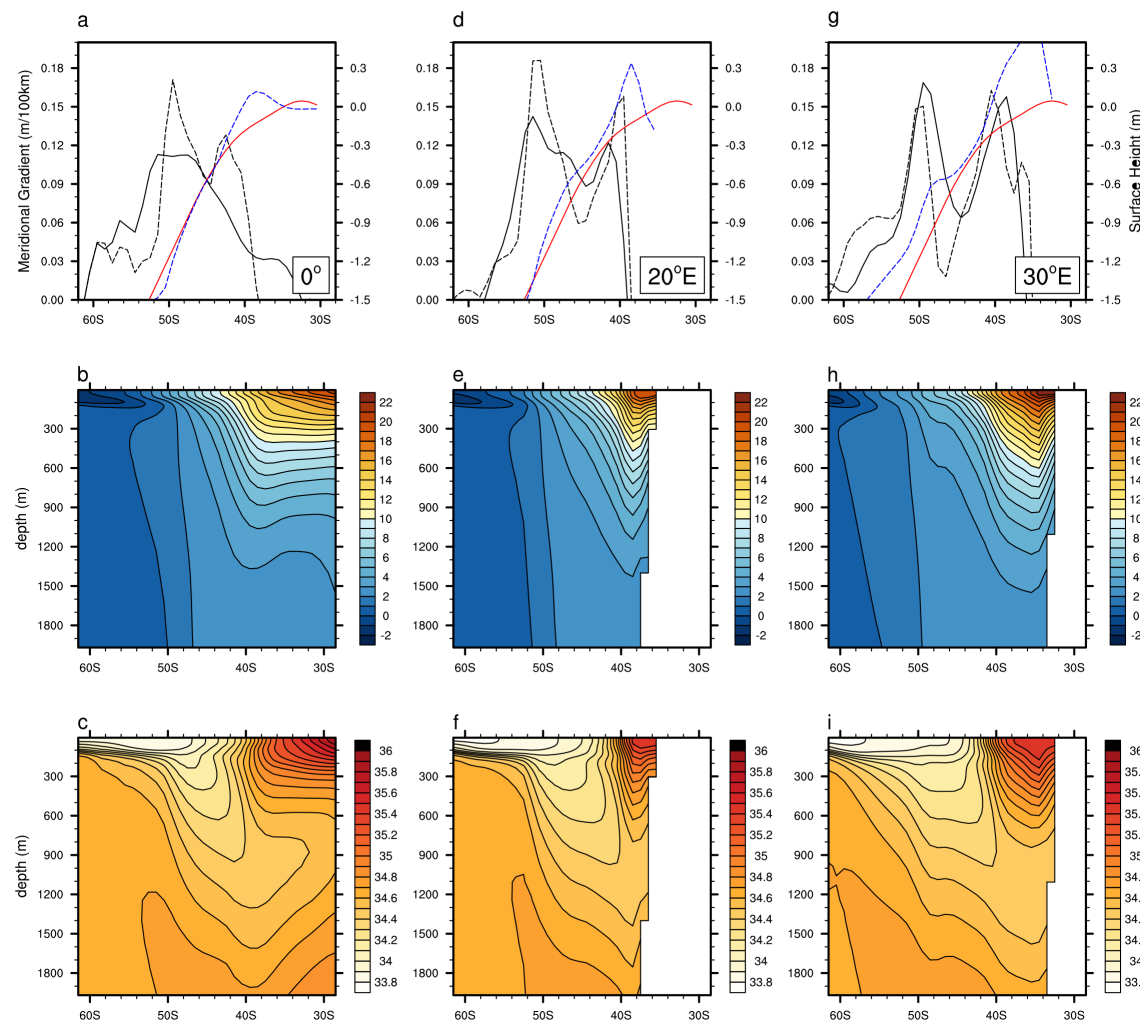

Figure 5.1: Upper panels: Meridional SSH gradients and $\mathrm{SSH}$ values from 30 to $60^{\circ} \mathrm{E}$ from ORAS4 (solid, red) and POP2 (dashed, blue) at (a) $0^{\circ}$, (b) $20^{\circ}$, (c) $30^{\circ}$ E. Red and blue lines represent SSH, whereas black lines represent the SSH gradients. Middle panels: potential temperature cross-sections from POP2 at (d) $0^{\circ}$, (e) $20^{\circ}$, (f) $30^{\circ} \mathrm{E}$. Lower panels: salinity cross-sections from POP2 at (g) $0^{\circ}$, (h) $20^{\circ}$, (i) $30^{\circ} \mathrm{E}$. 
The average between transects from 20 to $30^{\circ} \mathrm{E}$ was chosen to look for the SSH contour best associated to each meridional gradient peak as fronts are better distinguishable in this region (Fig.5.2). Also, this allows keeping the STF associated with the Agulhas Front/ARC.

The northernmost peak in the meridional gradient lies directly above a region of strongly vertically tilted isotherms and isohalines. This gradient extends from the surface to about $1200 \mathrm{~m}$ for potential temperature and about $800 \mathrm{~m}$ for salinity (Fig.5.2b,c respectively). Below these tilted isolines, the tongue-shaped salinity minimum associated with the AAIW can be found. North of this gradient, shallow waters with high salinity and temperature suggest that this is the region of the Agulhas Current (AC). These features fit the thermohaline criteria established by Orsi et al. (1995) and therefore are evidence that this surface meridional SSH gradient peak represents the Subtropical Front (STF), hereafter represented by the $S S H=0.15 \mathrm{~m}$ contour. As for the southern peak in meridional SSH gradient, it lies directly north of a subsurface potential temperature minimum and right over vertically tilted isotherms and isohalines that extend below $2000 \mathrm{~m}$ and up to about $1500 \mathrm{~m}$, respectively. This shows that this front is also consistent throughout the water column from surface to intermediate depths. According to its position and thermohaline criteria, it can be regarded as the Subantarctic Front (SAF), hereafter represented by the $S S H=-1.1 \mathrm{~m}$ contour. We note that, according to Swart et al. (2010) and Kim and Orsi (2014), it could be the Polar Front (PF) instead. However, since the model horizontal resolution is not high enough for these two fronts to be well separated from each other at this longitude, we have decided to consider it as the SAF. Front mean positions, as well as their respective trends throughout the period, are listed in Table 5.1.
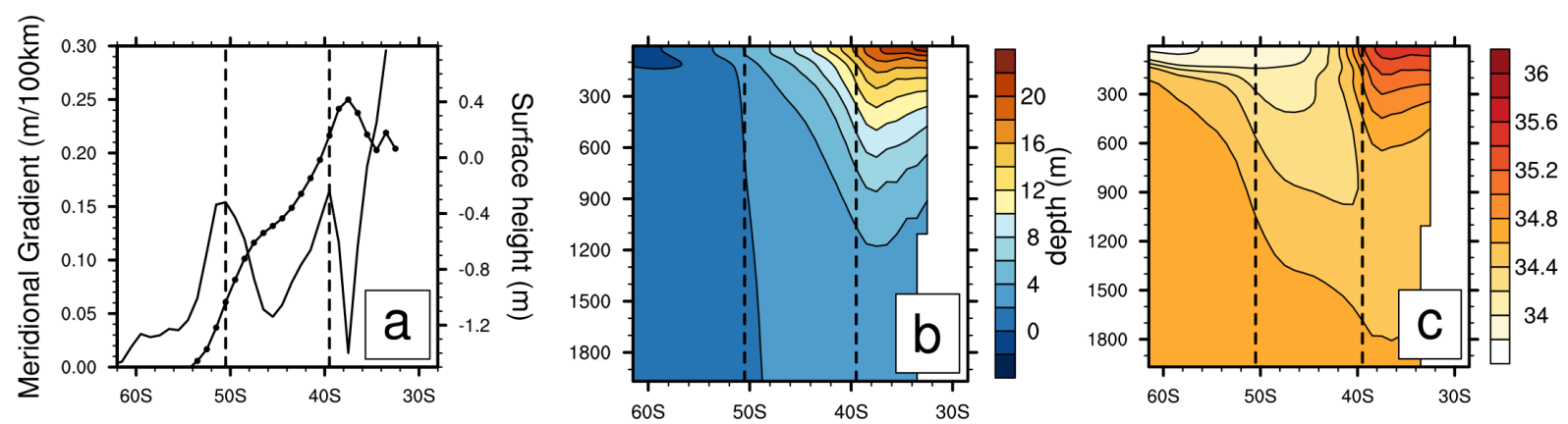

Figure 5.2: Cross-sections averaged between $20^{\circ} \mathrm{E}$ and $30^{\circ} \mathrm{E}$ of (a) Meridional SSH gradients (solid line) and SSH values (marked line); (b) Potential Temperature $\left({ }^{\circ} \mathrm{C}\right)$; (c) Salinity. Vertical dashed lines show the SAF (south) and STF (north) mean positions for an easier comparison between the three panels.

For assessing changes in time we looked at the variation of each contour mean position during the first five years (i.e., 1970-1974; Fig.5.3a) and during the last five years (i.e., 2005-2009; Fig.5.3b). Between $15^{\circ} \mathrm{E}$ and $40^{\circ} \mathrm{E}$, there is a southward displacement of 
the STF of roughly $45 \mathrm{~km}$ (Fig.5.4). It is worth mentioning that we consider only the southern branch of the $0.15 \mathrm{~m}$ contour to be the STF and east of $10^{\circ} \mathrm{E}$, which was the contour used for the time series in Fig.5.4b. Changes in the SSH gradient distribution can also be observed in Fig.5.3. As for the SAF, it shows a large zonal variability of its mean position. For example, its southward trend at $20^{\circ} \mathrm{E}$ is 4 times greater than the 20 to $30^{\circ} \mathrm{E}$ mean and the $30^{\circ} \mathrm{E}$ variation (Fig.5.5).

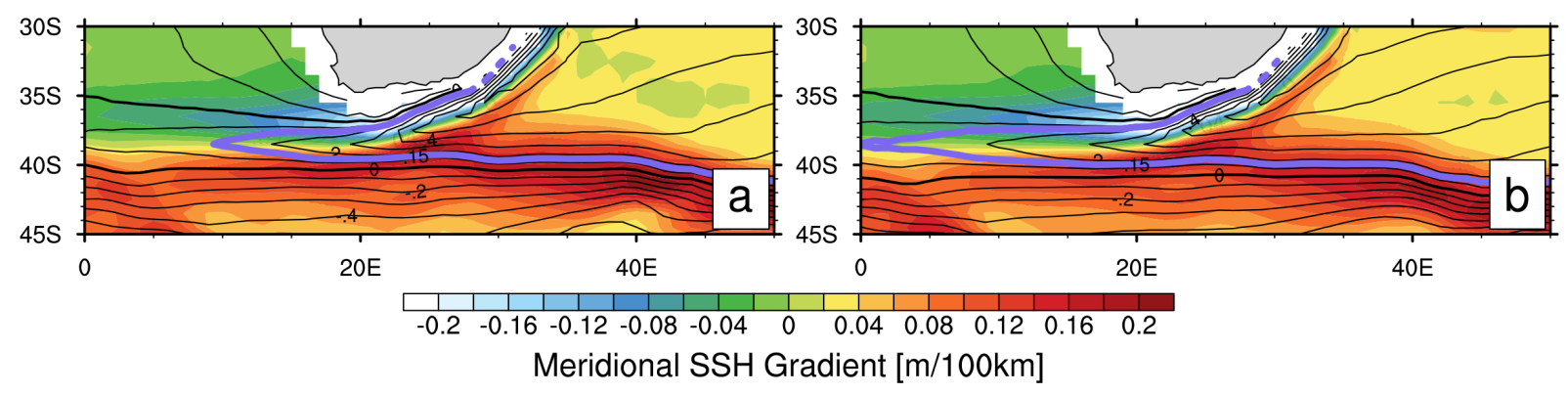

Figure 5.3: Meridional SSH gradient (shading) and SSH (contours) for the Agulhas region. (a) first five years average (1970-1974) and (b) last five years average (2005-2009). Purple line shows the $0.15 \mathrm{~m}$ contour used to track the STF position.
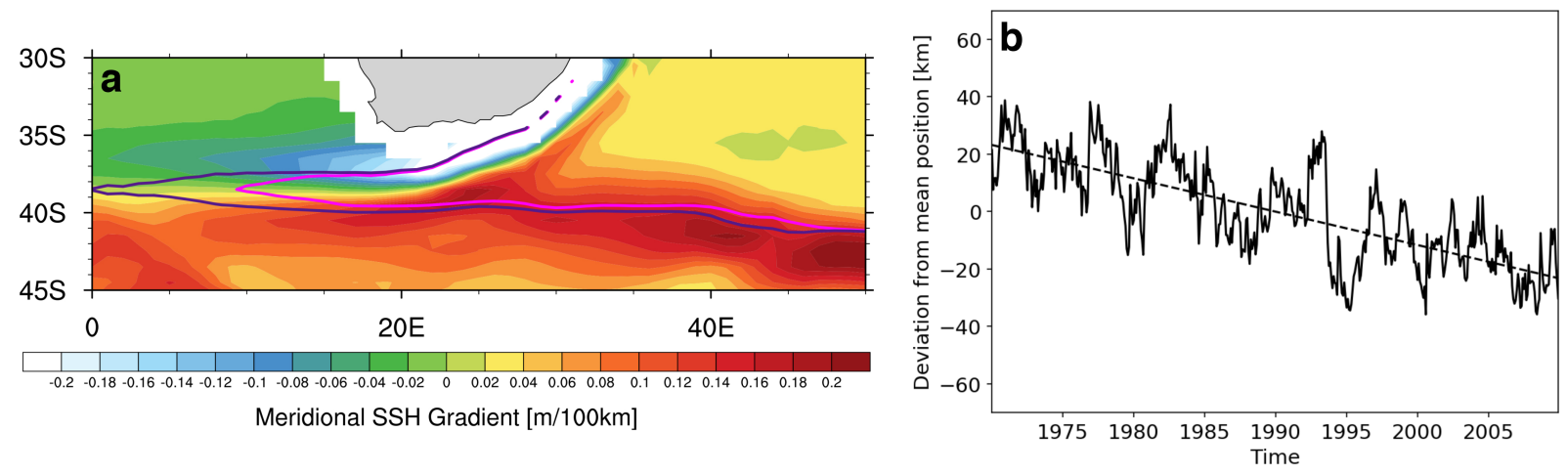

Figure 5.4: (a) Meridional SSH gradient mean for the 1970-2009 period (shading) and SSH contours for the STF mean position. Magenta line shows the 1970-1974 average and dark purple line shows the 2005-2009 average. (b) Time series of the deviations from the STF mean position between 1970 and 2009.

\subsection{Ocean Fronts Variation and Wind Stress Curl}

For the 40-year period analysed, the mean STF position is located at $39.5^{\circ} \mathrm{S}$, whereas the mean position of the $\mathrm{SAF}$ is at $50.5^{\circ} \mathrm{S}$. This means that the $\mathrm{SAF}$ is located at a latitude much closer to the zero WSC line than the STF, which is located $10^{\circ}$ to the north (Fig.5.6). The STF position is, in fact, closer to the latitude of highest WSC values. The STF shows very little zonal variation over the Agulhas region and shifts south at all longitudes, while 
the SAF has migrated south only close to $20^{\circ} \mathrm{E}$. West of $10^{\circ} \mathrm{E}$ there is virtually no change and east of about $25^{\circ} \mathrm{E}$, it has either migrated north or remained at the same position.

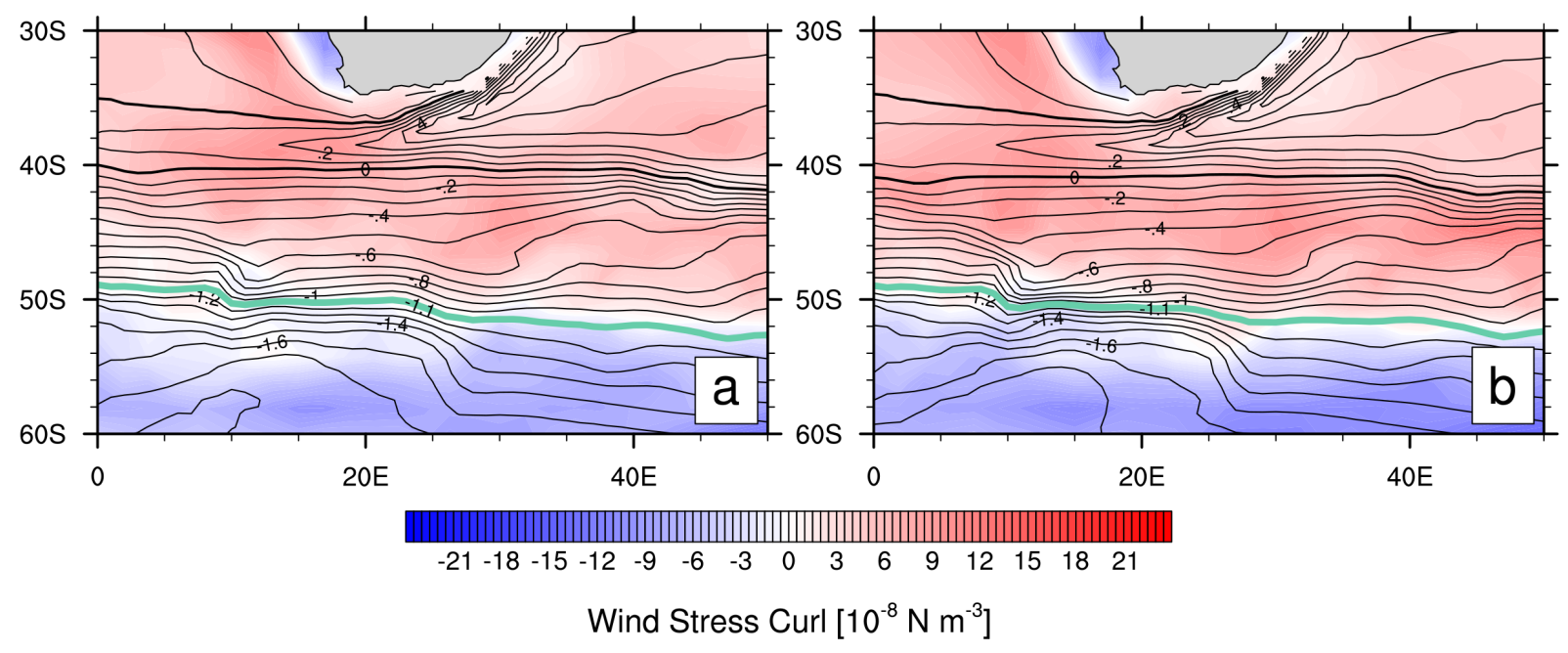

Figure 5.5: Wind Stress Curl (WSC; shading) and sea surface height (contours) for the Agulhas region. (a) first five years average (1970-1974) and (b) last five years average (2005-2009). Turquoise line shows the -1.1 m contour used to track the SAF position.

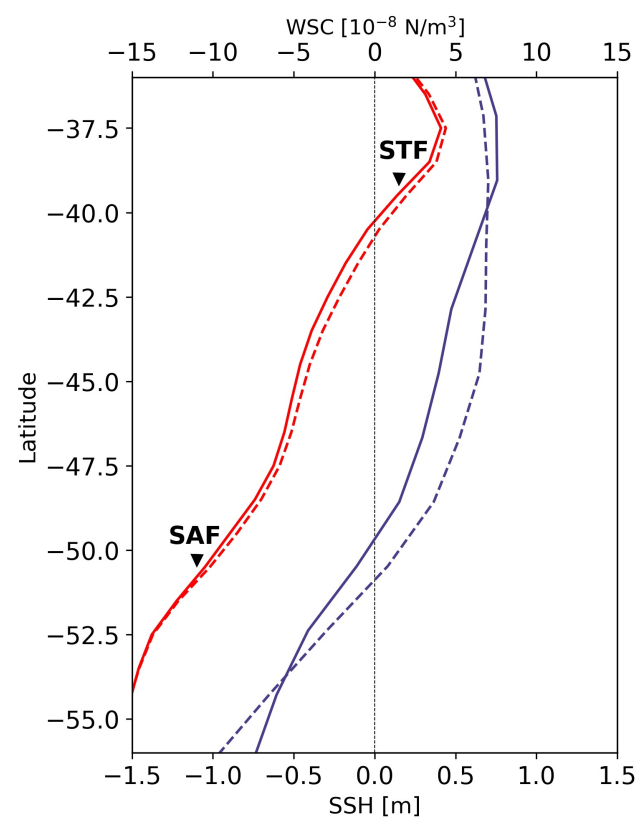

Figure 5.6: Meridional profile of SSH zonally averaged from $20^{\circ} \mathrm{E}$ to $30^{\circ} \mathrm{E}$ (red) and of zonally averaged WSC between $20^{\circ} \mathrm{E}$ and $100^{\circ} \mathrm{E}$ (dark blue). Solid lines represent the 1970-1974 average, while dashed lines represent the 2005-2009 average. Black triangles show where the SAF and the STF are located on the SSH curves. 
Table 5.1: Summary of both fronts identified, listing contours used for identification, their mean position and trends (in km/decade). Trends are significant over the $95 \%$ level.

\begin{tabular}{lccc}
\hline Front & SSH contour $(\mathbf{m})$ & Mean Position & Trend $(\mathrm{km} / \mathrm{dec})$ \\
STF & 0.15 & $39.5^{\circ} \mathrm{S}$ & -11.6 \\
SAF & -1.1 & $50.5^{\circ} \mathrm{S}$ & -6.0 \\
\hline
\end{tabular}

The WSC0 line does indeed migrate south at most longitudes between the Atlantic and the Indian Ocean (Fig.5.7a), but, at this time scale, its displacement at any longitude is much stronger than that of the STF or the SAF (i.e., it moves much further south than the fronts). The highest change in WSC happens over the Indian sector of the Southern Ocean and north of the WSC0 line, while much weaker changes happen elsewhere. This high WSC increase (the trend at this region is 1.5 to 2 times stronger than elsewhere in the Indian Ocean or the Agulhas region) is mostly due to an intensification and southward migration of the westerlies core ${ }^{1}$ (Figs.5.7b,c). At lower latitudes, a negligible southward migration is seen both for the Southeast Atlantic and the Indian Ocean basin, and no significant changes can be seen in the trade winds. Still, there is an increase in WSC over the Indian Ocean (Fig.5.7d).

Although both the STF at the Agulhas and WSC0 over the Indian Ocean (representing changes in the wind field) have shifted south, they do so at different rates $(11.6 \mathrm{~km} /$ decade and $36 \mathrm{~km} /$ decade respectively) and show different zonal structures. This, combined with the fact that the mean positions of these two features are more than $10^{\circ}$ of latitude apart and their weak correlation in time (strongest correlation of -0.19 when WSC0 lags by 6 months, Table 5.2), suggests that they bear no direct relationship, or at least it is not as direct as once thought. The SAF seems more directly related to WSC0 since its location coincides with it at $\sim 50.5^{\circ} \mathrm{S}$. The shift in the position of WSC0 (about 36 $\mathrm{km} /$ decade) is considerably stronger than that of the SAF at any longitude. At $20^{\circ} \mathrm{E}$, the SAF trend is strongest, shifting $24 \mathrm{~km} /$ decade. At $30^{\circ} \mathrm{E}$, no trend was found and an average between both longitudes yielded a southward trend of $6 \mathrm{~km} /$ decade. The total STF displacement was zonally uniform between $10^{\circ} \mathrm{E}$ and $30^{\circ} \mathrm{E}$. It shifted about $45 \mathrm{~km}$ south over 40 years, roughly $6 \%$ of the changes observed by Bard and Rickaby (2009) during stadial-interstadial shifts. During stadial periods (i.e., ice ages), the STF was located further north, as was the westerlies core. This constricted the area where inflow from the Indian to the Atlantic was possible at the Agulhas region. Conversely, during interstadial (i.e., interglacial) periods, since the STF is located further south (as is the westerlies core), there is a larger region over which this inflow to the Atlantic is possible. Considering that natural, pre-industrial shifts happened over tens of thousands of years,

\footnotetext{
${ }^{1}$ It is also important to remind that the WSC0 line is representative of the westerlies core, since the meridional wind shear is zero at the point where westerly winds reach their maximum strength. As can be seen in Figs. 5.7b and c, the WSC is positive to the north and negative south of the maximum.
} 
the rate of change found in the model over this period also suggests an anthropogenic impact over this region as discussed by Biastoch and Böning (2013).

If the westerlies, WSC0 and the STF all migrate south, but do not seem to be directly related, what could be forcing the STF changes or what could potentially link the two features? So far, changes do not seem to be locally forced. Next, we look at temperature and salinity variations over the mean STF region, before discussing Agulhas Current transports, leakage, and forcings.
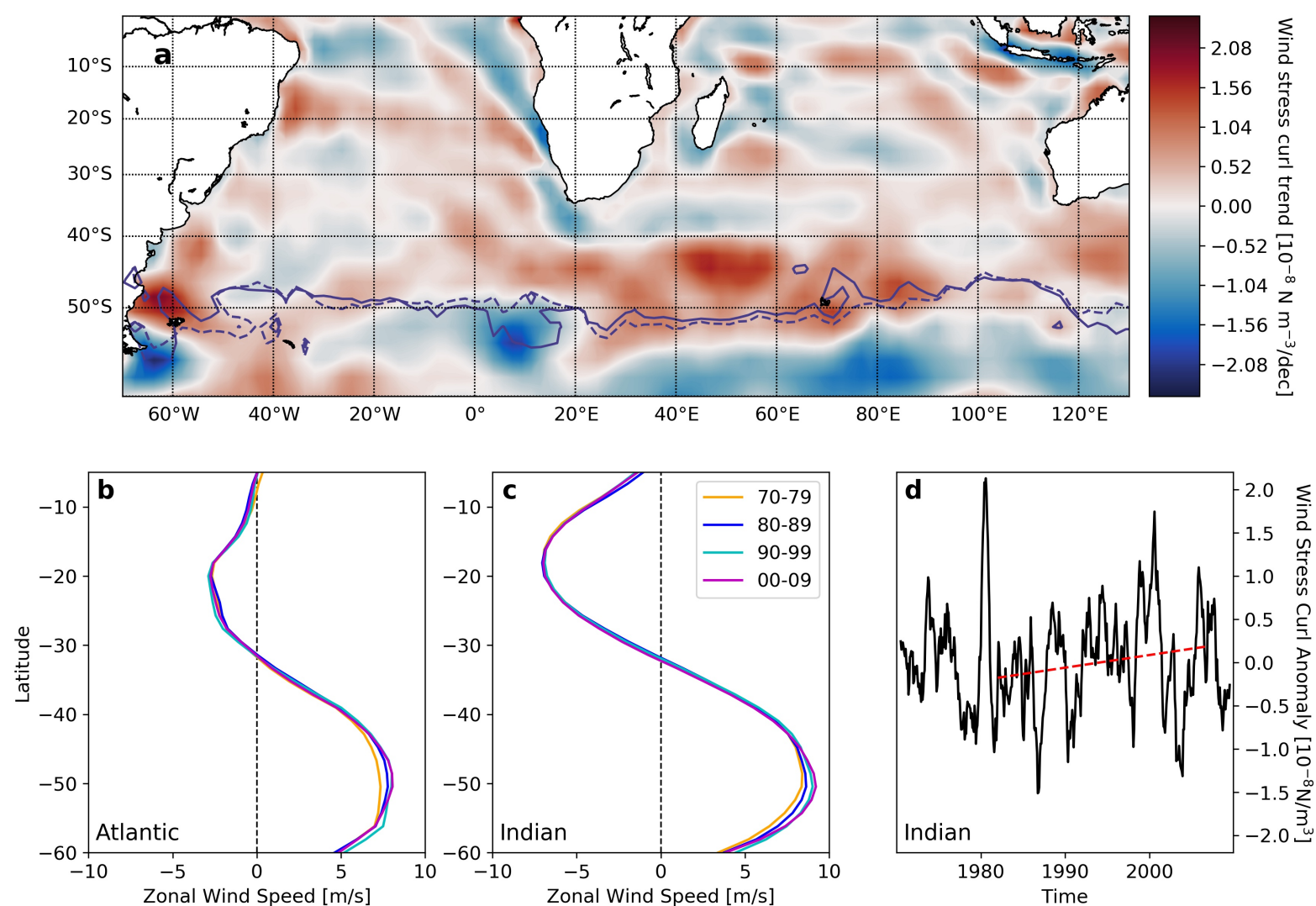

Figure 5.7: (a) Wind stress curl trends (shading) in $10^{-8} \mathrm{Nm}^{-3} \mathrm{dec}^{-1}$. Dark blue lines show the position of WSC0 for the first 5 (solid) and last 5 (dashed) years mean. (b) Decadal means Meridional profile of the Atlantic wind field $\left(40^{\circ} \mathrm{W}\right.$ to $20^{\circ} \mathrm{E}$ zonal average) in $\mathrm{m} / \mathrm{s}$; (c) Decadal means Meridional profile of the Indian wind field (50 to $100^{\circ} \mathrm{E}$ zonal average) in $\mathrm{m} / \mathrm{s}$; colors in both profiles show 70-79 (yellow), 80-89 (blue), 90-99 (turquoise) and 00-09 (purple) means. (d) Time series of wind stress curl $\left(10^{-8} \mathrm{Nm}^{-3}\right)$ averaged over $40-20^{\circ} \mathrm{S}$ and $50-100^{\circ} \mathrm{E}$ under a 12 -month running mean. The red dashed line shows the statistically significant (at 95\% confidence) linear trend between 1982 and 2009 trying to replicate the trend found by Rouault et al. (2009). 


\subsection{Temperature and Salinity changes}

Over the southeast Atlantic boundary, north of the STF mean position at $20^{\circ}$ E, there is a statistically significant increase in surface temperature of $0.06^{\circ} \mathrm{C}$ per decade (i.e., $0.24^{\circ} \mathrm{C}$ over the 40 -year analysed period; Fig.5.8). Stronger trends are observed closer to the STF mean position, reflecting the southward displacement of the warmer waters north of it towards a colder region. Trends observed south of the African coast are close to the values found throughout the southwestern Indian Ocean, and south of $45^{\circ} \mathrm{S}$, a predominant cooling trend is observed. Throughout the southwestern Indian Ocean, this positive trend could be seen as the basin-wide warming previously reported (Nitta and Yamada, 1989; Levitus et al., 2001; Lu et al., 2004; Levitus et al., 2005).

Salinity, on the other hand (Fig.5.9), increases until a sudden drop from 2002 onwards over the southwestern Indian Ocean and south of Africa (extending throughout the whole Indian Ocean, but starting at different times; not shown), which causes its trend to be negative for the 1970-2009 period ${ }^{2}$. Considering only the 1970-2002 period over the AC, it has a 0.02 /decade increase (Fig.5.9b). The southwestern Indian Ocean shows a similar positive trend, but salinity over the Mozambique Channel and the Eastern Madagascar Current (i.e., both west and east of Madagascar, the AC upstream branches) increases at about $0.05 /$ decade. This means that, regardless of the period to be considered (and therefore trend magnitude and sign), changes south of Africa over the Agulhas region are linked to changes over the southwestern Indian Ocean and upstream of the AC.

Similar variations in salinity (including the sudden drop) were found throughout the Indian ocean at lower latitudes (not shown). The spatial pattern of surface salinity trends agrees with surface precipitation (represented in the model by salinity fluxes; Fig.5.10a,b) and, when averaged throughout the whole basin, they show a correlation of -0.45 with surface salinity lagging by 6 months (Fig.5.10c,d). When looking exclusively at the $2002-$ 2009 period, trends are over twice as strong or even higher depending on the region. These results offer enough evidence for us to believe that the salinity drop after 2002 was most likely caused by the forcing surface salinity fluxes (i.e., how precipitation is forced in the model) over the entire Indian Ocean. Also, no changes in the ocean dynamics were found that could explain it. The spatial pattern of the trend until 2002 (Fig.5.10a) also bears some resemblance to the SST trends shown (Fig.5.8). Nevertheless, the model shows a coherent structure between the Indian and the Atlantic through the Agulhas region (as in observations) despite having an opposite trend.

\footnotetext{
${ }^{2}$ Although there is this sudden drop in salinity after 2002, it is important to highlight that it increases again during the last two years, but it does not reach pre-2002 values until the end of 2009.
} 


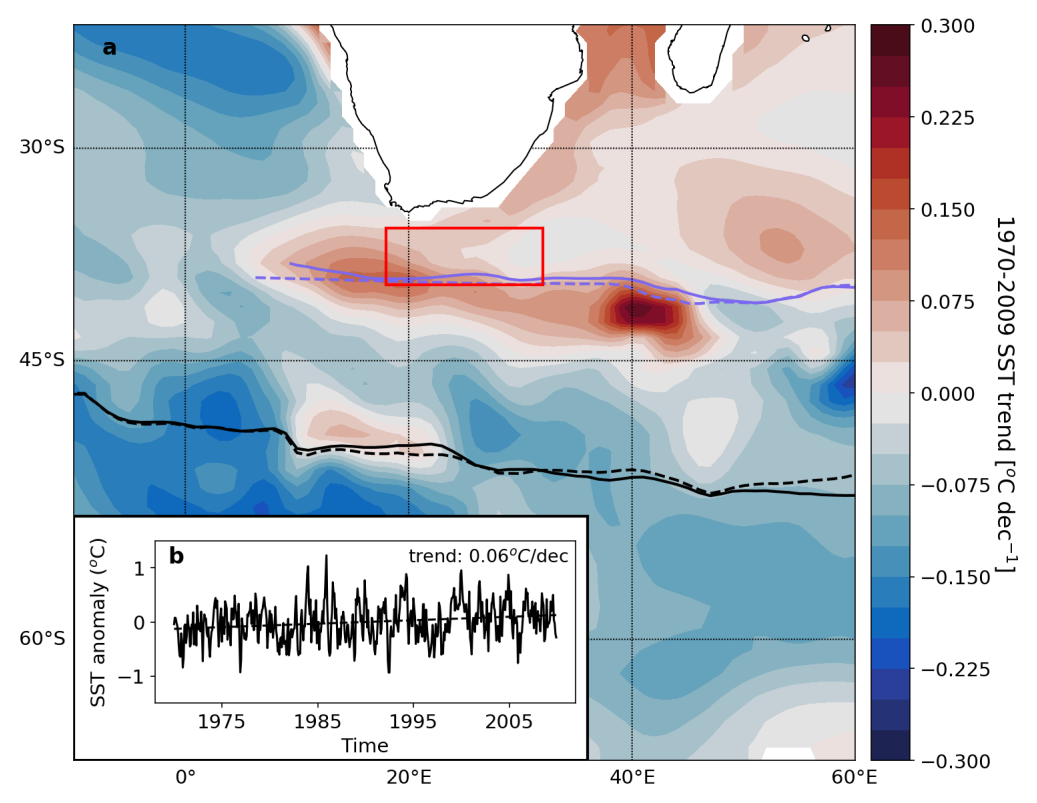

Figure 5.8: (a) Map of SST trends over the Agulhas region and (b) SST time series averaged over the region shown by the red box, which is the region of Agulhas Leakage in POP2. The lines represent the STF (purple) and SAF (black) associated contours. Solid lines represent the 1970-1974 mean and dashed lines represent the 2005-2009 mean.

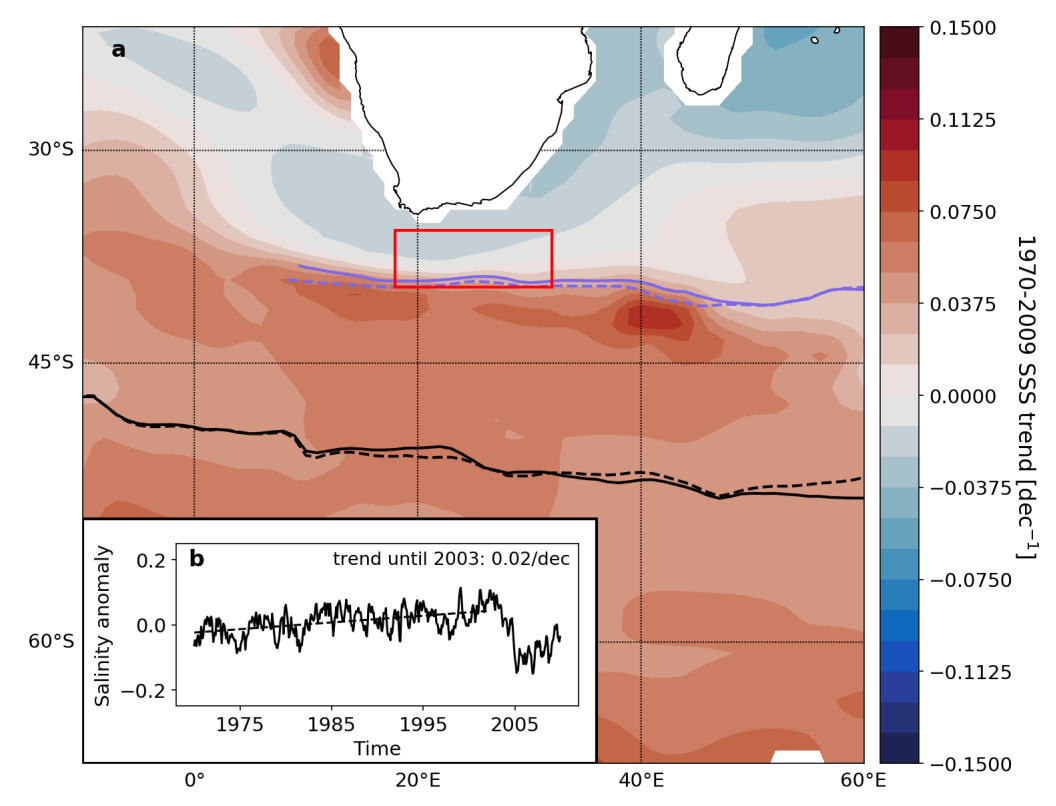

Figure 5.9: (a) Map of Sea Surface Salinity (SSS) trends over the Agulhas region and (b) SSS time series averaged over the region shown by the red box, which is the region of Agulhas Leakage in POP2. The lines represent the STF and the SAF as in Fig.5.8. 

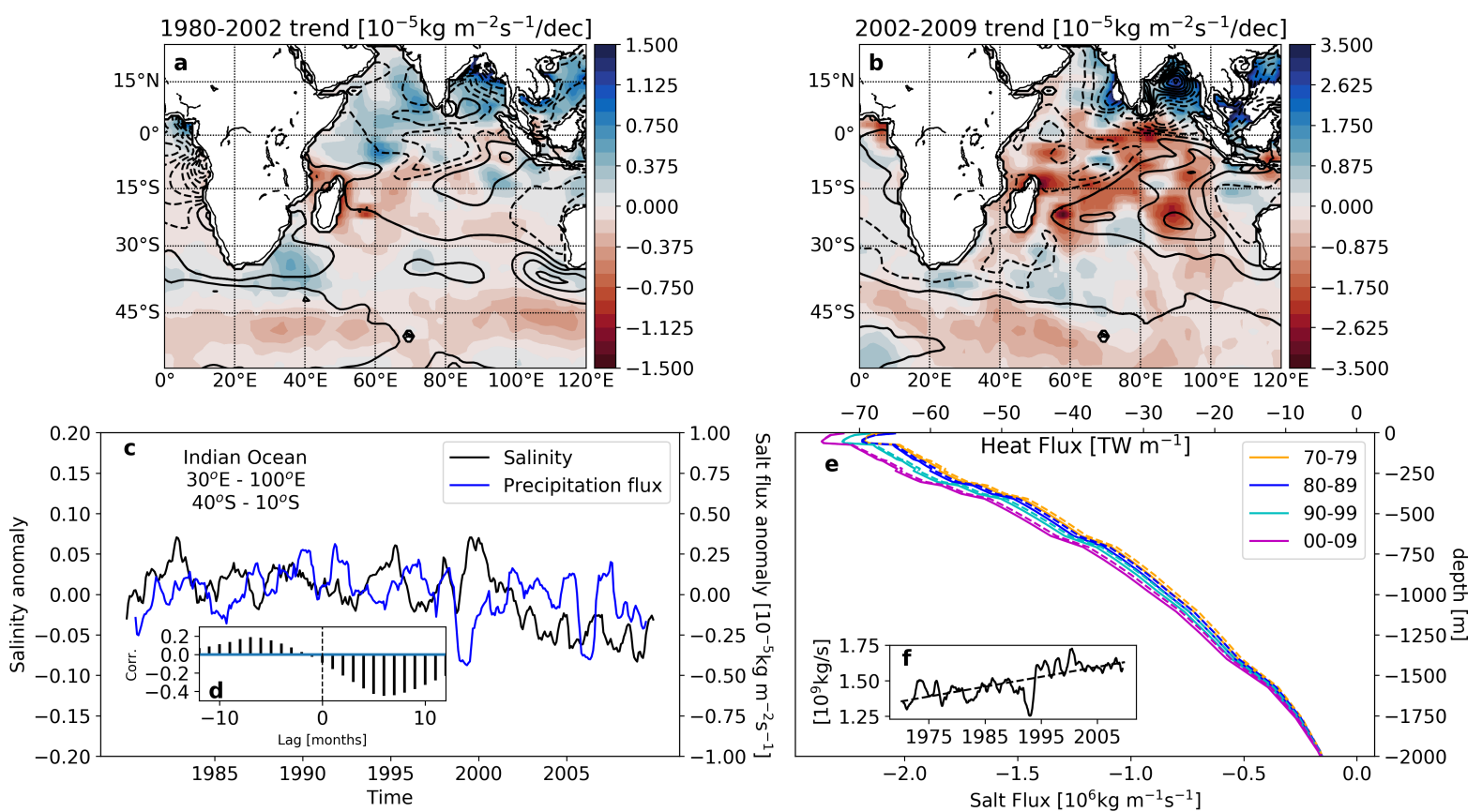

Figure 5.10: Changes in temperature and salinity from the Indian to the Atlantic. (a,b) Model precipitation flux trends (shading; $10^{-5} \mathrm{~kg} \mathrm{~m}^{-2} \mathrm{~s}^{-1} /$ decade) and surface salinity trends (contours; drawn every $0.05 \mathrm{~g} / \mathrm{kg}$ decade $^{-1}$ in [a] and every $0.2 \mathrm{~g} / \mathrm{kg} \mathrm{decade}^{-1}$ in [b]). The difference in scale was kept for trends to be visible in both plots. (a) shows 1980-2002 trends and (b) shows 2002-2009 trends. (c) Changes in precipitation (blue) and salinity (black) over the central Indian Ocean $\left(30-100^{\circ} \mathrm{E}, 40-10^{\circ} \mathrm{S}\right)$ and (d) their normed cross-correlation function. (e) Mean decadal (solid) salinity and (dashed) heat fluxes towards the Atlantic through the model's Agulhas Leakage. Colours denote same decades as in previous decadal profiles. (f) Upper $1500 \mathrm{~m}$ salt transport $\left[10^{9} \mathrm{~kg} / \mathrm{s}\right]$ towards the Atlantic through the "Leakage Current".

The $\theta$-S diagram for the four decades (1970s, 1980s, 1990s, and 2000s; Fig.5.11) shows that changes happen from the surface to the model's Lower Circumpolar Deep Water (LCDW). As expected, changes below the model's Antarctic Intermediate Water (AAIW) are very small. The most significant changes are observed in the upper layers. Waters above the $\sigma=27.4 \mathrm{~kg} / \mathrm{m}^{3}$ isopycnal (i.e., about $1200 \mathrm{~m}$ ) show an increase in potential temperature, which is consistent with observations for the Indian and Atlantic Oceans (Levitus et al., 2001, 2005).

On the other hand, salinity decreases from this deeper layer until the $\sigma=26.5 \mathrm{~kg} / \mathrm{m}^{3}$ isopycnal (at roughly $220 \mathrm{~m}$ ) and increases afterwards up to the surface. In other words, it has increased everywhere except for the AAIW layer, where it has decreased. This suggests that only at the upper layers (i.e., above $220 \mathrm{~m}$ ) there is an increase in the amount of salt these already saltier waters are carrying into the Atlantic, while other changes are taking place over the AAIW and the Subantarctic Mode Water (SAMW). 
It is also worth mentioning that the salinity changes seen on intermediate to subsurface layers (i.e., above and including AAIW) and over the Indian Ocean before 2003 match observations (Boyer et al., 2005; Durack and Wijffels, 2010).

Despite vertical variations, heat and salt fluxes towards the Atlantic have increased from decade to decade, as did salt transport (Fig.5.10e,f), suggesting that velocity variability might play a stronger role than temperature or salinity variations for transporting heat or salt from the Indian to the Atlantic. Choosing a reference salinity for the flux calculations, over which we would compute the deviations, could lead to different results (Weijer and Van Sebille, 2014). Since salinity was shown to be highly variable due to changes in the surface forcings, computing fluxes using deviations from a reference average salinity value did not improve the flux estimates (not shown). Still, our results indicate that the changes over the AAIW are also carried through this leakage current, as they are embedded in the $1500 \mathrm{~m}$ deep leakage flow shown in the flux profiles (Fig. $5.10 \mathrm{e})$.

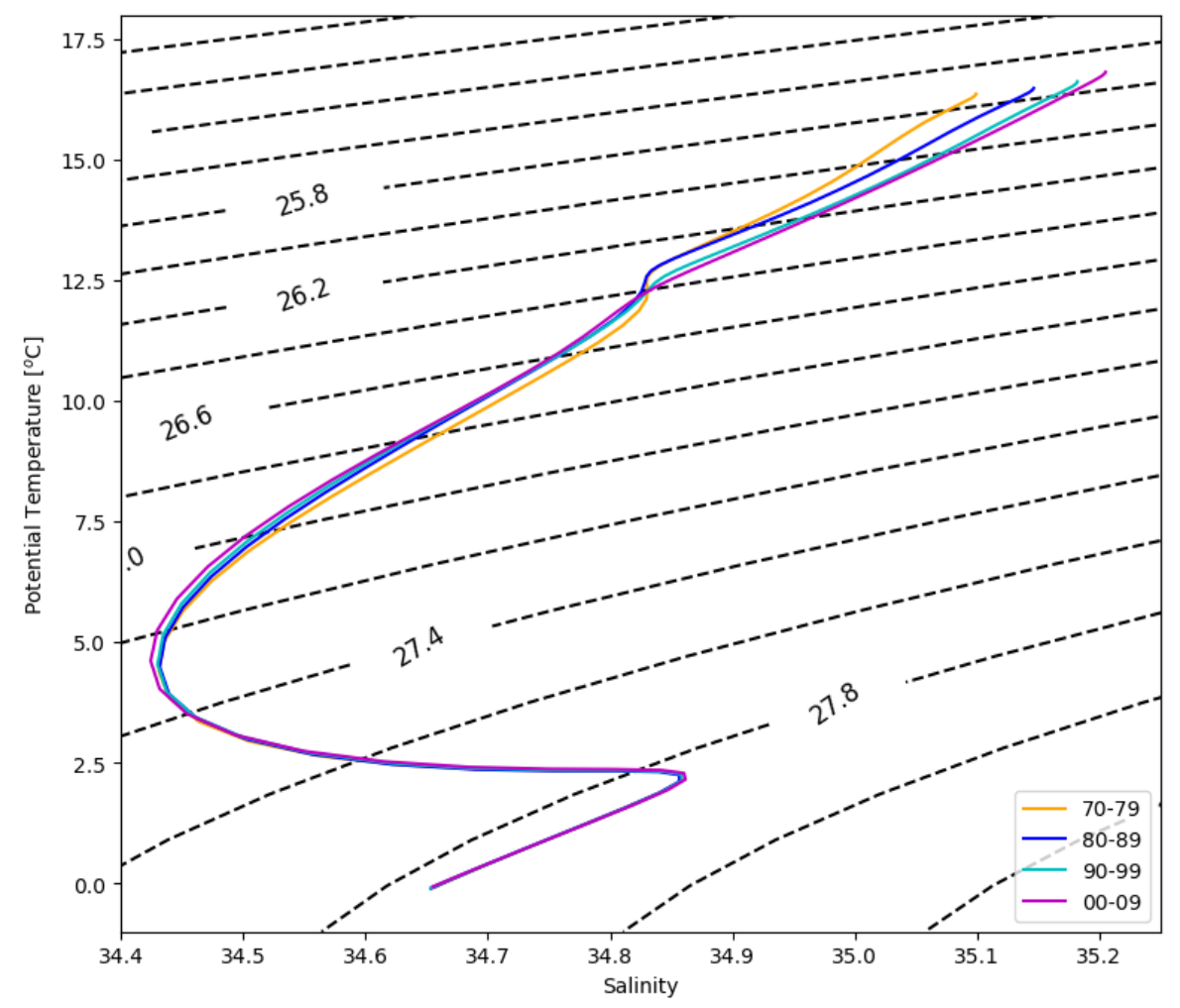

Figure 5.11: $\theta$-S diagram for waters north of the STF mean position. Decadal means are shown: (brown) 1960-1969; (blue) 1980-1989; (magenta) 2000-2009. 


\subsection{Velocity and transport changes}

The Agulhas Leakage in the model is represented by a viscous flow in a boundary layer that emerges from the retroflection system as a bifurcation (Fig.5.12). For this reason, transport values are greatly overestimated, which is why we have not focused on absolute values, but rather on anomalies and trends.
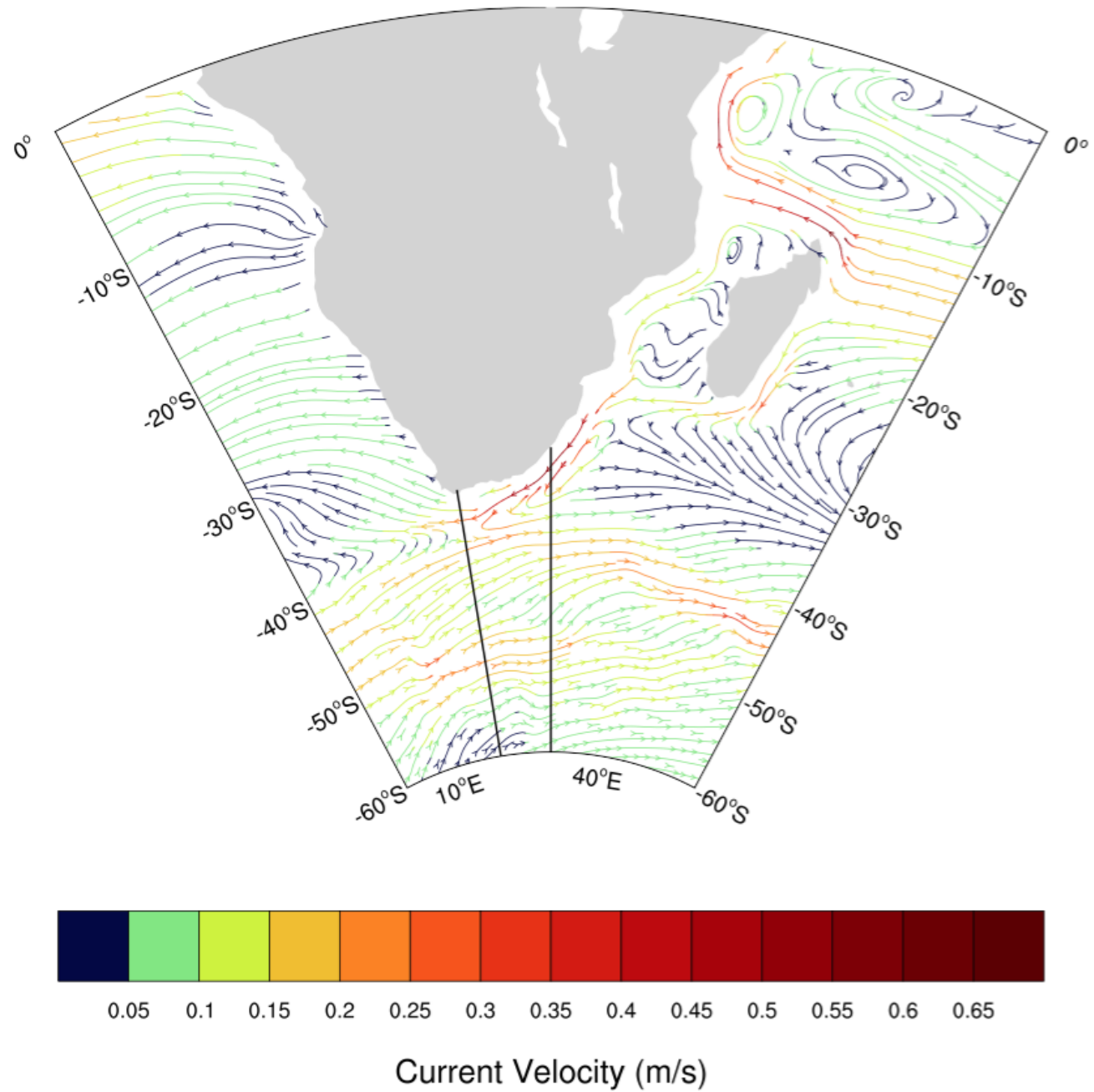

Figure 5.12: Streamlines of the surface velocity over the Agulhas region. Colors show velocity values in $\mathrm{m} / \mathrm{s}$. The lines show the transects at $20^{\circ} \mathrm{E}$ and $30^{\circ} \mathrm{E}$ for reference.

The model results show that Agulhas Leakage intensifies at $20^{\circ} \mathrm{E}$ and extents from the surface to $1600 \mathrm{~m}$ (Fig. 5.13a), in agreement with previous studies (Bryden and Beal, 2001; Rouault et al., 2009). We calculated its transport by integrating the westward velocity at the same $20^{\circ} \mathrm{E}$ cross-section (dotted rectangle in Fig. 5.13a), and its anomaly can be seen in Fig.5.13b. The average transport of $41 \mathrm{~Sv}$ obtained with POP2 is comparable to the $43 \mathrm{~Sv}$ found by Weijer et al. (2012) using the same ocean model in a coupled setup. It showed an increase of about $6 \mathrm{~Sv}$ in 40 years $(1.5 \mathrm{~Sv} /$ decade), comparable to the $5 \mathrm{~Sv}$ found by Biastoch et al. (2009). Its variation in time is well correlated to the STF position 
(-0.76 at lag zero; Table 5.2). It was not correlated, however, to the WSC0 position (-0.14 when WSC0 leads by one month; Table 5.2). The SAF associated jet also intensifies (Fig.5.13a). However, it seems to be tightening (i.e., its northern edge is weakening while its core intensifies) while the boundary current associated to the $\mathrm{AC}$ leakage seems to be broadening (i.e., trends are not centred over the core of this current).

Since changes in the velocity field structure at the $20^{\circ} \mathrm{E}$ cross-section also indicate that the Agulhas Leakage current could be either broadening or slightly moving south, we test this hypothesis based on Beal and Elipot (2016), who show through observations that instead of intensifying, the AC broadens due to increased eddy activity. Although our model does not allow eddies, it is possible to calculate the eddy kinetic energy (EKE) through the velocity fluctuations compared to computed geostrophic velocities (as explained in section 3-Methods). Consistent with Beal and Elipot (2016), there is an increase in EKE (at a very similar rate) over the Agulhas Current and its Leakage Current (Fig.5.14). As expected, the correlation between EKE and the Leakage transport at $20^{\circ} \mathrm{E}$ is very high when filtering out high-frequency variability $(R=0.87$ when EKE leads transport by 1 month; Table 5.2). However, broadening or increased EKE of this current itself cannot explain the STF southward shift. By using the position where zonal velocity is zero as an index for the edge of the Leakage Current, we found its southward displacement to be statistically significant, but too small and too subject to interpolation to be a robust indicator of the current broadening or displacement. Its correlation with EKE at $20^{\circ} \mathrm{E}$ was also weak (-0.36 when EKE lags by 3 months; Table 5.2).
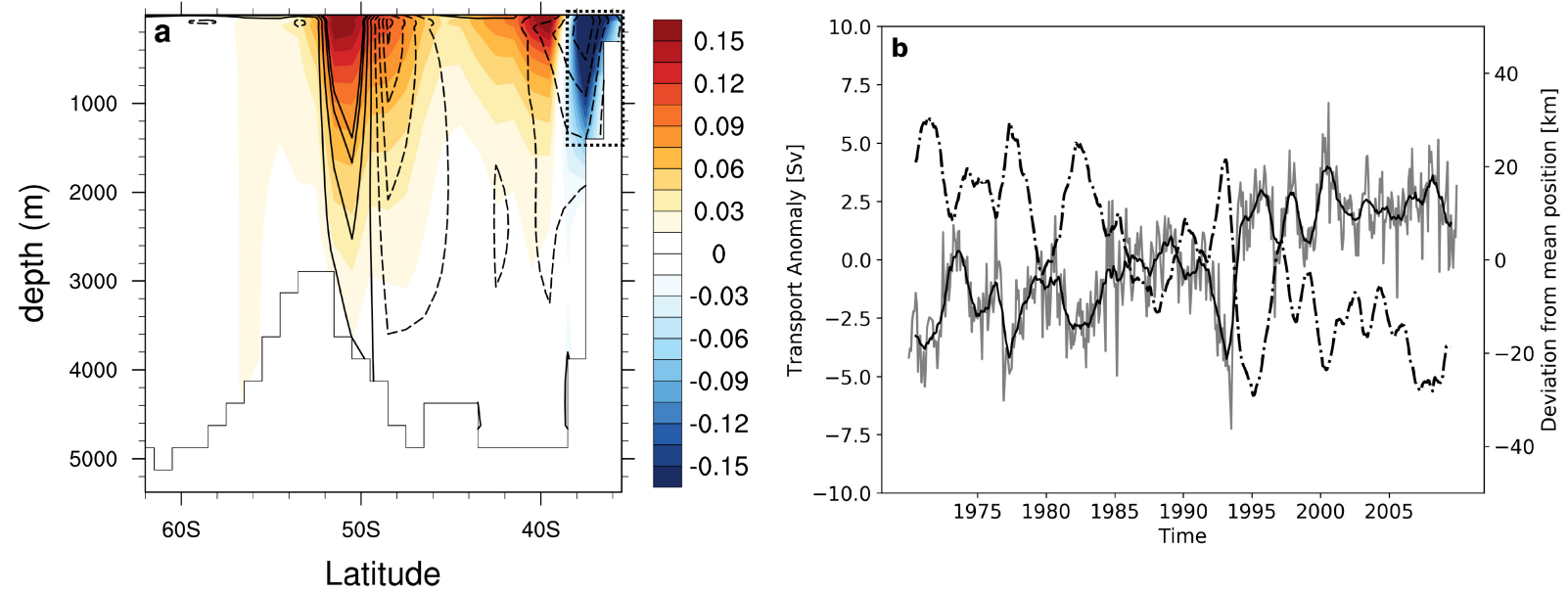

Figure 5.13: (a) Meridional cross-section of mean zonal velocity (shading, $\mathrm{m} / \mathrm{s}$ ) and its trend (each line denotes a $0.2 \mathrm{~cm} / \mathrm{s} \mathrm{month}^{-1}$ trend; solid for positive and dashed for negative) at $20^{\circ} \mathrm{E}$. (b) Solid lines show time series of Agulhas leakage transport anomaly (gray, Sv; $1 \mathrm{~Sv}=10^{6} \mathrm{~m}^{3} / \mathrm{s}$ ) for the dotted area in (a) and its 12 -month running mean (black). The dash-dotted line shows the STF deviation from its mean position in kilometers as in Fig. 5.4, but under a 12-month running mean. 


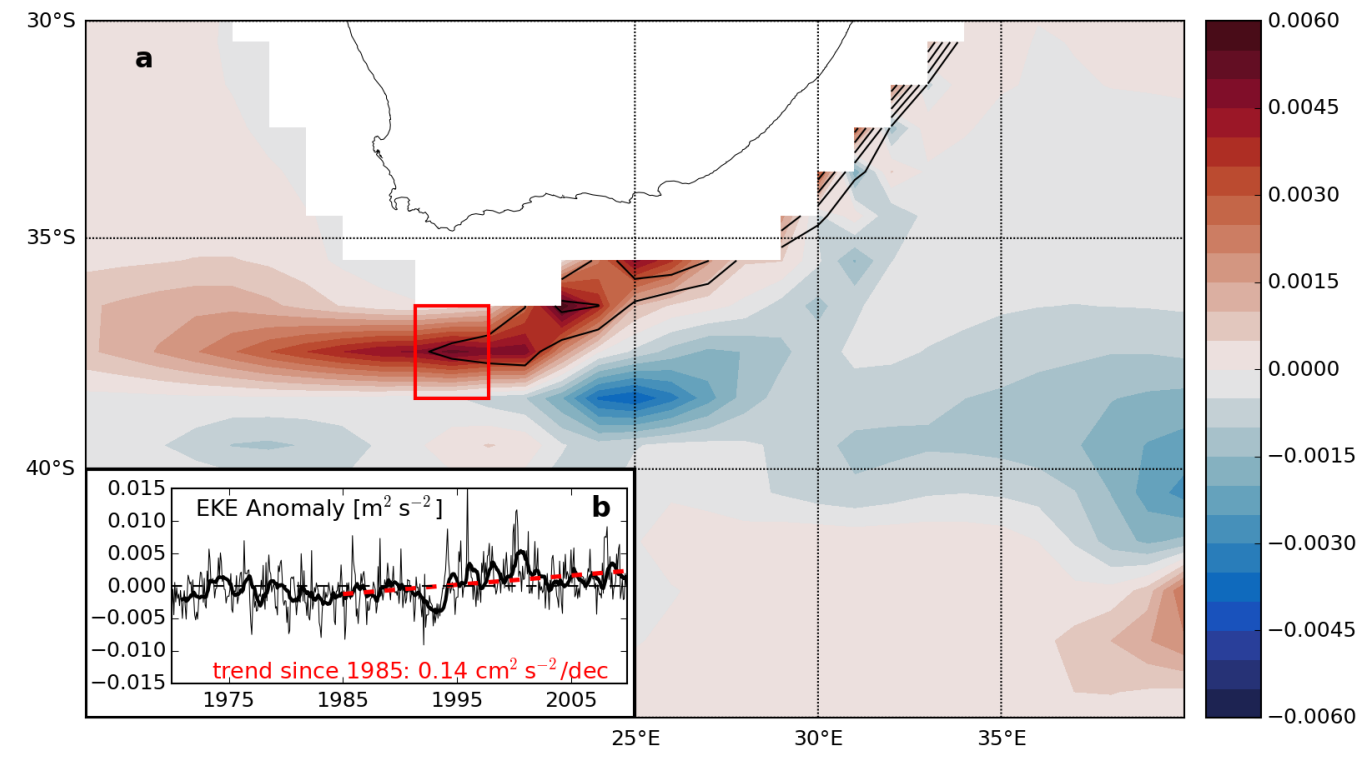

Figure 5.14: (a) Eddy Kinetic Energy trends (shading; $\mathrm{m}^{2} \mathrm{~s}^{-2}$ ) and mean values (contours only represent regions of highest EKE corresponding to the Agulhas Current and to the Agulhas Leakage). (b) Eddy Kinetic Energy at $20^{\circ}$ E over the Agulhas Leakage Current. Trend listed in red for the 1985-2009 period for comparison with the work of Beal \& Elipot (2016).

$\mathrm{AC}$ transport at $30^{\circ} \mathrm{E}$ has increased by roughly $1.3 \mathrm{~Sv}(0.32 \mathrm{~Sv} /$ decade; Fig.5.15a). The ARC transport, on the other hand, has decreased by $4.4 \mathrm{~Sv}$ (1.1 Sv/decade; Fig.5.15b). It can be seen that the $\mathrm{AC}$ transport at $30^{\circ} \mathrm{E}$ shows a much smaller change than the other main currents, but is still in line with an intensification of the entire current system. An increase of WSC over the Indian Ocean was also found, which could explain the strengthening of this current system. Since transport towards the Atlantic is well correlated to the STF position, the results obtained so far suggest that changes in the STF mean latitude and in the current transports at the Agulhas region could be connected to larger scale changes.

The Barotropic Stream Function (BSF) field can be used to look at large scale changes over the two ocean basins. Changes in BSF (Fig.5.16a) show that not only is there an intensification of the circulation over both South Atlantic and Indian subtropical gyres (and the whole Supergyre), but also an increase in recirculation at the southwestern Indian Ocean. Since the position of the zero BSF contour (hereafter BSF0) can be used as an index of the Subtropical Gyre southern border displacement (as it is its dynamical boundary), it is natural to see how it changes in time at the Agulhas region. Indeed, there is a significant southward displacement of the BSF0 at $20^{\circ} \mathrm{E}$ (Fig.5.16b) and an overall intensification of the Indian Ocean subtropical gyre (Fig.5.16c).

The BSF0 has shifted south throughout the Indian and Atlantic ocean basins, but at a much stronger pace over the Agulhas region (Fig.5.17). This goes against the topographic 

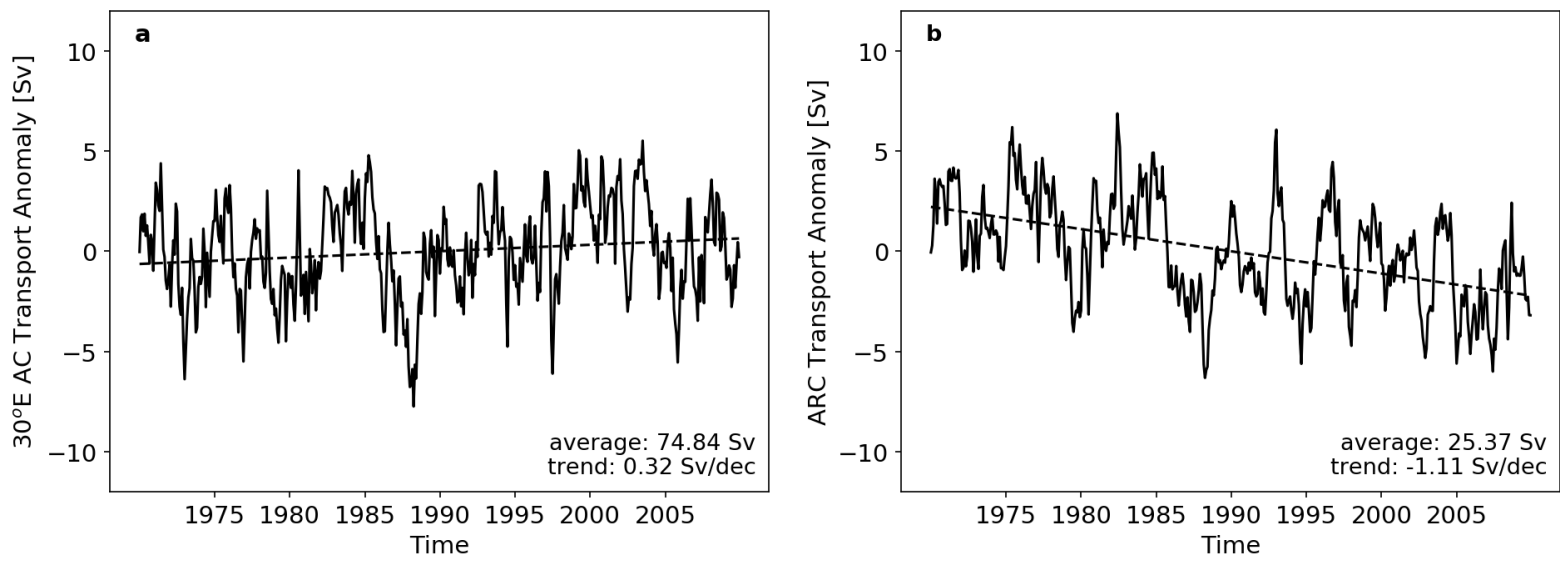

Figure 5.15: Transport (in Sv) time series of (a) Agulhas Current at $30^{\circ} \mathrm{E}$ and (b) Agulhas Return Current at $30^{\circ} \mathrm{E}$.

control suggested by Boer et al. (2013). According to their results, the STF should show no shift in its position, since changes would be constricted by the bottom topography. The correlation between the STF and BSF0 positions at the same region is $\mathrm{R}=0.57$ with BSF0 leading STF by one month (Table 5.2). This suggests a strong link between both variables although the BSF0 trend is almost three times as high as the STF (35 $\mathrm{km} /$ decade and $11.6 \mathrm{~km} /$ decade respectively). The STF trend over the Agulhas is very similar to the BSF0 trend between $30^{\circ} \mathrm{W}$ and Greenwich.

In order to quantify changes in the subtropical gyres circulation and extent, two indices were used. First, gyre strength was calculated as the anomaly of the mean BSF over the region where it has negative values (i.e., the subtropical gyres). Second, gyre extent was calculated as the anomaly of the total area where BSF is negative. A double 12-month running mean was applied in order to reduce high-frequency variability. Strength and extent indices are presented in Figs. 5.18a and b, respectively. As shown, both Atlantic and Indian subtropical gyres intensify (and therefore the Supergyre) and the Indian Ocean shows an expansion trend, especially from the early 1990's onwards.

The Indian gyre (and the Supergyre) intensification can partly explain the AC velocity increase and the increased leakage in our model. The transport at $20^{\circ} \mathrm{E}$ is well correlated to the strength of both Indian and Atlantic gyres as well as the Supergyre. The lags of maximum correlations suggest this response to take 4 to 6 months (Table 5.2). The increase in WSC over the Indian Ocean (Fig.5.7d) is most likely the cause, even though it is statistically significant (as reported by Rouault et al., 2009) in our data only when filtering out higher frequency variability and only considering the 1980's to 2009 period. Most of this WSC increase is attributable to the westerlies strengthening, since no changes can be seen in the trade winds in the CORE dataset (Fig.5.7c). This agrees with the results of Durgadoo et al. (2013), who showed the Agulhas leakage to respond to stronger westerlies rather than the WSC0 position. Their proposed mechanism is more local. According 

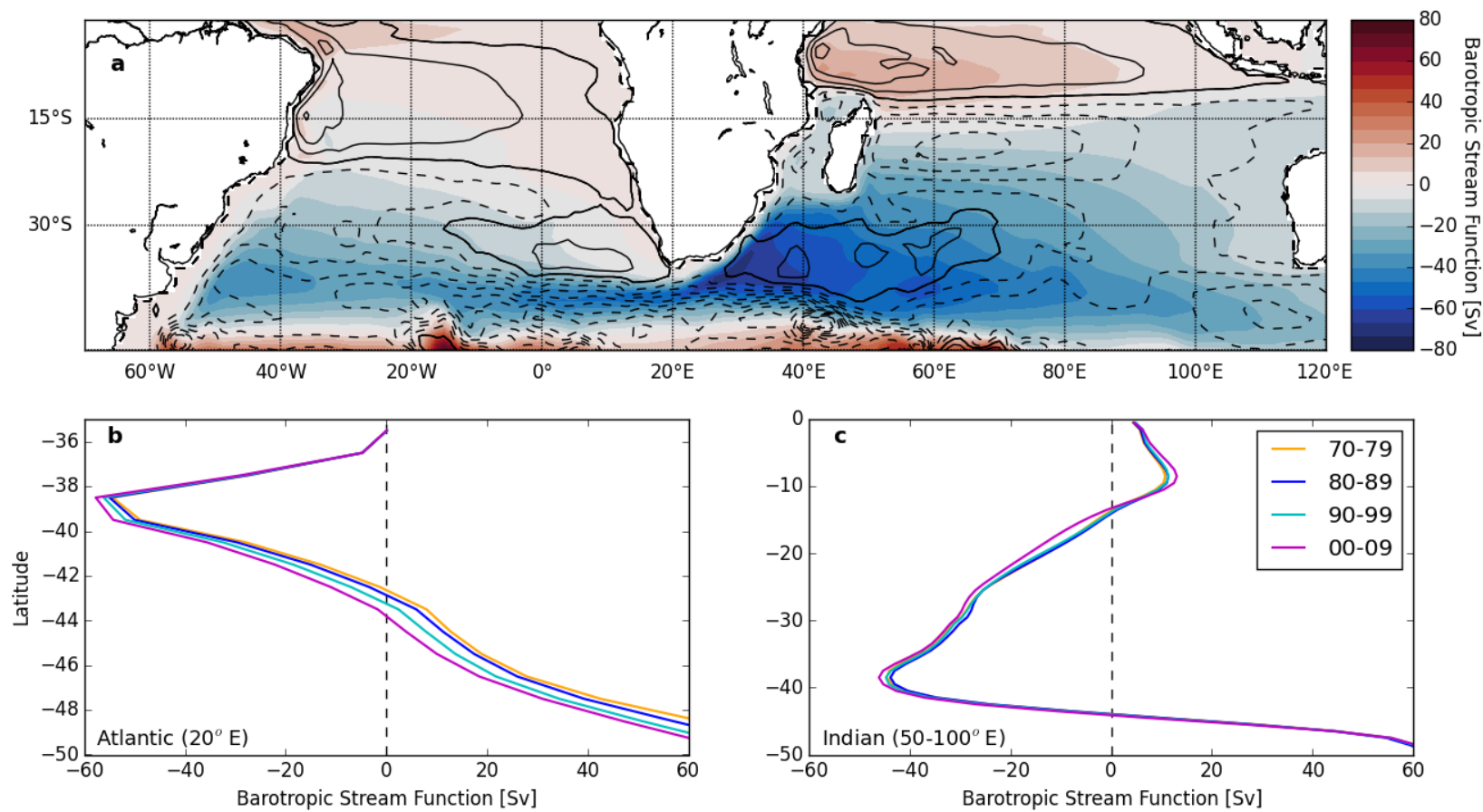

Figure 5.16: (a) Barotropic Stream Function (Sv) over the Supergyre: 1970-2009 average represented by the shading while positive (negative) trends are represented by solid (dashed) contours; (b) Meridional profile of the BSF at $20^{\circ} \mathrm{E}$; (c) Meridional profile of the BSF over the Indian Ocean (50-100 E average).

to Durgadoo et al. (2013), stronger westerlies increase WSC over the Indian sector of the Southern Ocean, which in turn increases downward Ekman pumping. As a result, the ocean interior responds with increased northward transport that is compensated by increased leakage. Our results show an increase in WSC over the Indian Ocean sector of the Southern Ocean, meaning that both the gyre strengthening and the response to an increased Ekman pumping could be in action in the model. The uniform southward displacement of BSF0 is a reflection of the Indian Gyre expansion, which is stronger from the early 1990's onwards (as is the BSF0 shift over the Agulhas/Southeast Atlantic). Kim and Orsi (2014) have already discussed the influence of an intensification of the Indian subtropical gyre, which works with the WSC0 shift to expand it polewards. This results in the displacement of Antarctic Circumpolar Current fronts in the eastern side of the Indian Ocean sector of the Southern Ocean. Here we find the STF to also respond to this expansion but on the western side of the Indian Ocean subtropical gyre.

We now have enough evidence to believe that changes in the STF position can be related to changes over the strength and the expansion of the Indian subtropical gyre: (i) the expansion of the Indian subtropical gyre (especially over the Agulhas region), (ii) the consistency between an intensification of the circulation and the transport observed at $20^{\circ} \mathrm{E}$, and (iii) the good agreement between the BSF0 and the STF variations. 


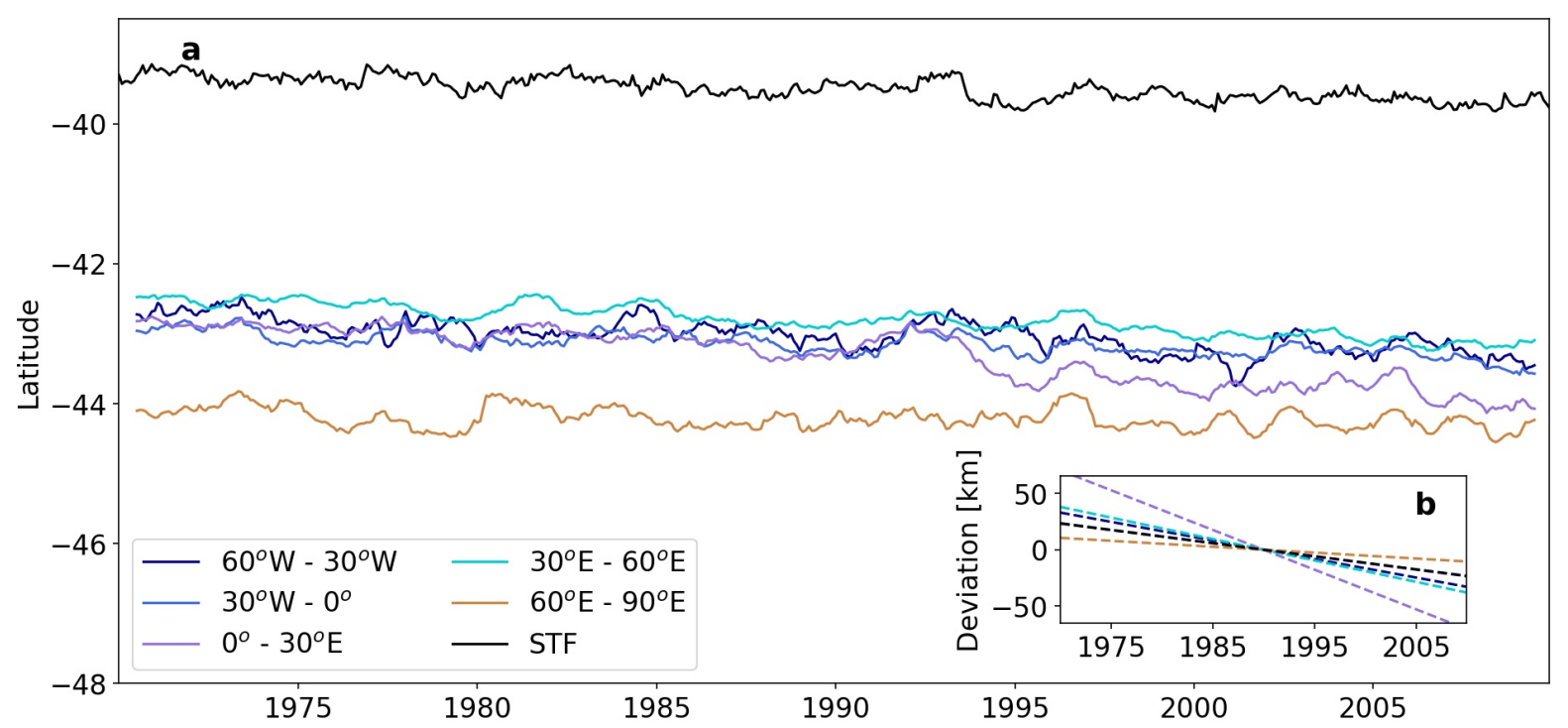

Figure 5.17: (a) Variation of the meridional position of averaged BSF0 between $60^{\circ} \mathrm{W}$ and $30^{\circ} \mathrm{W}$ (dark blue), $30^{\circ} \mathrm{W}$ and $0^{\circ}$ (blue), $0^{\circ}$ and $30^{\circ} \mathrm{E}$ (purple), $30^{\circ} \mathrm{E}$ and $60^{\circ} \mathrm{E}$ (turquoise), $60^{\circ} \mathrm{E}$ and $90^{\circ} \mathrm{E}$ (brown), and the STF (black). All series had their seasonal cycles removed and only the BSF0 series had a 12-month running mean applied to them. (b) Linear trends of the series shown in (a) in terms of deviation from their mean position (in $\mathrm{km}$ ). Trends and series were separated for clarity.
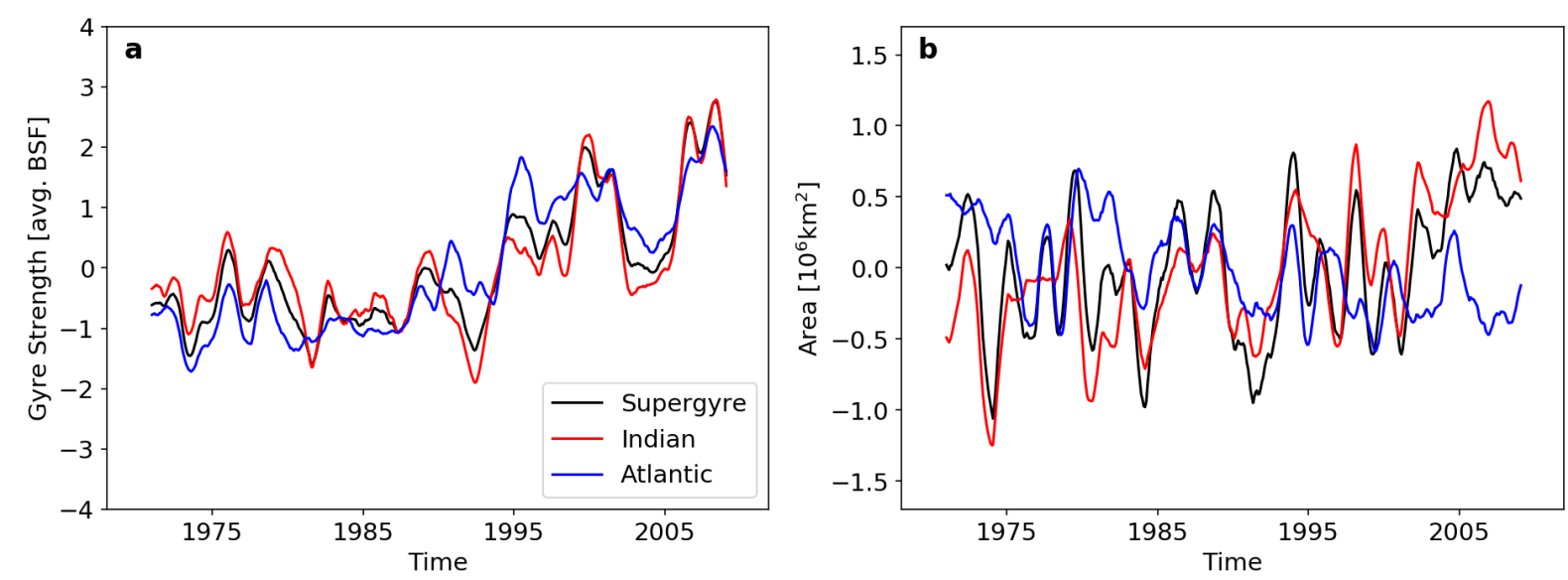

Figure 5.18: Twelve-month running means of (a) Gyre strength for the Supergyre (black) and separately for the Atlantic (blue) Indian (red) oceans. (b) Gyre extent (in $10^{6} \mathrm{~km}^{2}$ ) colour-coded as in (a). Gyre strength was calculated as the average BSF over the region where it is negative. Extent was calculated as the area integral over the region where BSF is negative. 
Table 5.2: Lagged Pearson correlation coefficients between relevant indexes and variables. $R_{\text {max }}$ stands for the maximum correlation, followed by its lag. $R_{0}$ denotes the correlation at zero lag. All results are significant over 95\%. Series were compared under a 12-month running mean unless otherwise noted in the text (e.g., Gyre indices).

\begin{tabular}{lccc}
\hline & $R_{\max }$ & Lag of $R_{\max }$ & $R_{0}$ \\
WSC0 Position vs. STF Position & -0.19 & 6 & -0.11 \\
STF Position vs. Transport at $20^{\circ} \mathrm{E}$ & -0.76 & 0 & -0.76 \\
STF Position vs. BSF0 Position & 0.57 & 1 & 0.56 \\
Transport at $20^{\circ} \mathrm{E}$ vs. Supergyre Strength & 0.56 & 6 & 0.47 \\
Transport at $20^{\circ} \mathrm{E}$ vs. Atlantic Gyre Strength & 0.44 & 4 & 0.41 \\
Transport at $20^{\circ} \mathrm{E}$ vs. Indian Gyre Strength & 0.59 & 5 & 0.52 \\
EKE at $20^{\circ} \mathrm{E}$ vs. Transport at $20^{\circ} \mathrm{E}$ & 0.87 & -1 & 0.86 \\
EKE at $20^{\circ} \mathrm{E}$ vs. Position of u $=0$ & -0.36 & 3 & -0.33 \\
WSC0 Position vs. Transport at $20^{\circ} \mathrm{E}$ & -0.14 & -1 & -0.11 \\
\hline
\end{tabular}

\section{Summary and Conclusions}

Multiple definitions of the Subtropical Front have been associated with changes in the southern boundary of the southern hemisphere subtropical gyres via a direct relationship with the zero wind stress curl line. In this study, we investigated this association using the ocean component of the NCAR-CESM forced by the CORE dataset. We compared the STF behaviour to the actual dynamical features that represent the gyre boundary and its possible forcing mechanisms.

We identified two distinct fronts over the transition between the Atlantic and the Indian oceans. They were considered the SAF (southern, at $50.5^{\circ} \mathrm{S}$ ) and the STF (northern, at $39.5^{\circ} \mathrm{S}$ ) according to their mean position and features in potential temperature and salinity cross-sections. Changes in their position were assessed by tracking in time the position of a specific SSH contour throughout our 40-year analysis period from 1970 to 2009. The contour was selected considering the one that was best associated with the local maximum SSH gradient (-1.1 $\mathrm{m}$ for the SAF and $0.15 \mathrm{~m}$ for the STF)

Although both fronts migrate south, as well as the latitude of WSC0 which was believed to be the controlling factor of the STF position Ruijter et al. (e.g., 1999); Beal et al. (e.g., 2011), they are about 10 degrees in latitude apart and not correlated in time at any lag. A slight yet statistically significant increase in wind stress curl over the Indian Ocean was observed, as well as an increase in westerlies intensity over the Southern Ocean of about $1 \mathrm{~m} / \mathrm{s}$ (i.e., roughly 12\%) and a southward shift of its core.

Accompanied by this increase in wind stress curl, an increase in transport of the Agulhas leakage of $6 \mathrm{~Sv}$ over 40 years was observed, which was shown to be part of 
a larger scale gyre spin-up and increase. An upstream increase of roughly $1.3 \mathrm{~Sv}$ over 40 years was observed, consistent with the strengthening of the recirculation cell of the Southwestern Indian Ocean. Not only has the Indian Subtropical gyre intensified, it has also expanded. Our results show that the stronger westerly winds were responsible for such changes.

The increased leakage happens from the surface down to about $1600 \mathrm{~m}$, in agreement with previous studies for the Agulhas Current (Bryden and Beal, 2001; Rouault et al., 2009). Although precipitation does change salinity over a wide region of the Indian Ocean, the amount of salt carried into the Atlantic is much more dependent on leakage variability. It is important to keep in mind that POP2 overestimates the Agulhas Leakage. Thus, considerations regarding transport and flux changes are most likely a reflection of the gyre-scale intensification.

In the time scales analysed in this study, the STF position was shown to be largely connected to the Supergyre expansion, especially over the Indian ocean. Although the whole Indian Subtropical gyre expands, the BSF0 position had its largest southward displacement right over the Agulhas region. The results confirm that changes in the large-scale wind stress forcing (rather than local) influence changes in the STF position. Subtropical Gyre dynamics are essentially forced by the wind field and its stress applied to the ocean over the entire basin. Although WSC0 and BSF0 lines are the actual agents that represent the southern edge of subtropical gyres, over the last decades the STF has followed the Supergyre dynamics and moved with it. 


\section{References}

Alory, G., S. Wijffels, and G. Meyers (2007). Observed temperature trends in the indian ocean over 1960-1999 and associated mechanisms. Geophysical Research Letters 34(2).

Andrews, J. C. (1977). Eddy structure and the west australian current. Deep Sea Research 24(12), 1133-1148.

Balmaseda, M. A., K. Mogensen, and A. T. Weaver (2013). Evaluation of the ecmwf ocean reanalysis system oras4. Quarterly Journal of the Royal Meteorological Society 139(674), 1132-1161.

Bard, E. and R. E. Rickaby (2009). Migration of the subtropical front as a modulator of glacial climate. Nature 460(7253), 380-383.

Beal, L. M., W. P. De Ruijter, A. Biastoch, R. Zahn, et al. (2011). On the role of the agulhas system in ocean circulation and climate. Nature 472(7344), 429-436.

Beal, L. M. and S. Elipot (2016). Broadening not strengthening of the agulhas current since the early 1990s. Nature 540(7634), 570-573.

Belkin, I. M. and A. L. Gordon (1996). Southern ocean fronts from the greenwich meridian to tasmania. Journal of Geophysical Research: Oceans (1978-2012) 101(C2), 36753696.

Biastoch, A. and C. W. Böning (2013). Anthropogenic impact on agulhas leakage. Geophysical Research Letters 40(6), 1138-1143.

Biastoch, A., C. W. Böning, and J. Lutjeharms (2008). Agulhas leakage dynamics affects decadal variability in atlantic overturning circulation. Nature 456(7221), 489-492.

Biastoch, A., C. W. Böning, F. U. Schwarzkopf, and J. Lutjeharms (2009). Increase in agulhas leakage due to poleward shift of southern hemisphere westerlies. $\mathrm{Na}$ ture 462 (7272), 495-498.

Billany, W., S. Swart, J. Hermes, and C. Reason (2010). Variability of the southern ocean fronts at the greenwich meridian. Journal of Marine Systems 82(4), 304-310.

Boebel, O., J. Lutjeharms, C. Schmid, W. Zenk, T. Rossby, and C. Barron (2003). The cape cauldron: a regime of turbulent inter-ocean exchange. Deep Sea Research Part II: Topical Studies in Oceanography 50(1), 57-86.

Boer, A. M., R. M. Graham, M. D. Thomas, and K. E. Kohfeld (2013). The control of the southern hemisphere westerlies on the position of the subtropical front. Journal of Geophysical Research: Oceans 118(10), 5669-5675. 
Böning, C. W., A. Dispert, M. Visbeck, S. Rintoul, and F. U. Schwarzkopf (2008). The response of the antarctic circumpolar current to recent climate change. Nature Geoscience 1(12), 864-869.

Boyer, T. P., S. Levitus, J. Antonov, R. Locarnini, and H. Garcia (2005). Linear trends in salinity for the world ocean, 1955-1998. Geophysical Research Letters 32(1).

Bryden, H. L. and L. M. Beal (2001). Role of the agulhas current in indian ocean circulation and associated heat and freshwater fluxes. Deep Sea Research Part I: Oceanographic Research Papers 48(8), 1821-1845.

Carter, L., I. McCave, and M. J. Williams (2008). Circulation and water masses of the southern ocean: a review. Developments in Earth and Environmental Sciences 8, $85-114$.

Chapman, C. C. (2014). Southern ocean jets and how to find them: Improving and comparing common jet detection methods. Journal of Geophysical Research: Oceans 119(7), 4318-4339.

da Silveira, I. C., L. B. Miranda, and W. S. Brown (1994). On the origins of the north brazil current. Journal of Geophysical Research: Oceans (1978-2012) 99(C11), 2250122512.

Danabasoglu, G., S. C. Bates, B. P. Briegleb, S. R. Jayne, M. Jochum, W. G. Large, S. Peacock, and S. G. Yeager (2012). The ccsm4 ocean component. Journal of Climate 25(5), 1361-1389.

de Ruijter, W. P. and D. B. Boudra (1985). The wind-driven circulation in the south atlantic-indian ocean-i. numerical experiments in a one-layer model. Deep Sea Research Part A. Oceanographic Research Papers 32(5), 557-574.

Deacon, G. (1982). Physical and biological zonation in the southern ocean. Deep Sea Research Part A. Oceanographic Research Papers 29(1), 1-15.

Deacon, G. E. (1933). A general account of the hydrology of the south atlantic ocean. Discovery Reports (7), 171-238.

Dee, D., S. Uppala, A. Simmons, P. Berrisford, P. Poli, S. Kobayashi, U. Andrae, M. Balmaseda, G. Balsamo, P. Bauer, et al. (2011). The era-interim reanalysis: Configuration and performance of the data assimilation system. Quarterly Journal of the royal meteorological society 137(656), 553-597.

Dencausse, G., M. Arhan, and S. Speich (2011). Is there a continuous subtropical front south of africa? Journal of Geophysical Research: Oceans (1978-2012) 116(C2), C02027. 
Downes, S. M., R. Farneti, P. Uotila, S. M. Griffies, S. J. Marsland, D. Bailey, E. Behrens, M. Bentsen, D. Bi, A. Biastoch, et al. (2015). An assessment of southern ocean water masses and sea ice during 1988-2007 in a suite of interannual core-ii simulations. Ocean Modelling 94, 67-94.

Durack, P. J. and S. E. Wijffels (2010). Fifty-year trends in global ocean salinities and their relationship to broad-scale warming. Journal of Climate 23(16), 4342-4362.

Durgadoo, J. V., B. R. Loveday, C. J. Reason, P. Penven, and A. Biastoch (2013). Agulhas leakage predominantly responds to the southern hemisphere westerlies. Journal of Physical Oceanography 43(10), 2113-2131.

England, M. H. (1992). On the formation of antarctic intermediate and bottom water in ocean general circulation models. Journal of Physical Oceanography 22(8), 918-926.

Garzoli, S. L. and R. Matano (2011). The south atlantic and the atlantic meridional overturning circulation. Deep Sea Research Part II: Topical Studies in Oceanography 58(17), $1837-1847$.

Gent, P. R. (2016). Effects of southern hemisphere wind changes on the meridional overturning circulation in ocean models. Annual review of marine science 8, 79-94.

Gent, P. R. and J. C. Mcwilliams (1990). Isopycnal mixing in ocean circulation models. Journal of Physical Oceanography 20(1), 150-155.

Gill, A. and E. Schumann (1979). Topographically induced changes in the structure of an inertial coastal jet: application to the agulhas current. Journal of Physical Oceanography 9(5), 975-991.

Godfrey, J. (1996). The effect of the indonesian throughflow on ocean circulation and heat exchange with the atmosphere: A review. Journal of Geophysical Research: Oceans 101 (C5), 12217-12237.

Goni, G. J. and I. Wainer (2001). Investigation of the brazil current front variability from altimeter data. Journal of Geophysical Research: Oceans (1978-2012) 106(C12), $31117-31128$.

Gordon, A. L., S. Ma, D. B. Olson, P. Hacker, A. Ffield, L. D. Talley, D. Wilson, and M. Baringer (1997). Advection and diffusion of indonesian throughflow water within the indian ocean south equatorial current. Geophysical Research Letters 24 (21), 2573-2576.

Gordon, A. L., R. F. Weiss, W. M. Smethie, and M. J. Warner (1992). Thermocline and intermediate water communication between the south atlantic and indian oceans. Journal of Geophysical Research: Oceans 97(C5), 7223-7240. 
Graham, R. M. and A. M. Boer (2013). The dynamical subtropical front. Journal of Geophysical Research: Oceans 118(10), 5676-5685.

Graham, R. M., A. M. Boer, K. J. Heywood, M. R. Chapman, and D. P. Stevens (2012). Southern ocean fronts: Controlled by wind or topography? Journal of Geophysical Research: Oceans 117(C8).

Ingleby, B. and M. Huddleston (2007). Quality control of ocean temperature and salinity profiles-historical and real-time data. Journal of Marine Systems 65(1), 158-175.

Kalnay, E., M. Kanamitsu, R. Kistler, W. Collins, D. Deaven, L. Gandin, M. Iredell, S. Saha, G. White, J. Woollen, et al. (1996). The ncep/ncar 40-year reanalysis project. Bulletin of the American meteorological Society $77(3), 437-471$.

Kim, Y. S. and A. H. Orsi (2014). On the variability of antarctic circumpolar current fronts inferred from 1992-2011 altimetry. Journal of Physical Oceanography 44(12), 3054-3071.

Knorr, G. and G. Lohmann (2003). Southern ocean origin for the resumption of atlantic thermohaline circulation during deglaciation. Nature 424 (6948), 532-536.

Knorr, G. and G. Lohmann (2007). Rapid transitions in the atlantic thermohaline circulation triggered by global warming and meltwater during the last deglaciation. Geochemistry, Geophysics, Geosystems 8(12).

Large, W. and S. Pond (1981). Open ocean momentum flux measurements in moderate to strong winds. Journal of physical oceanography 11(3), 324-336.

Large, W. and S. Yeager (2009). The global climatology of an interannually varying air-sea flux data set. Climate dynamics 33(2-3), 341-364.

Levitus, S., J. Antonov, and T. Boyer (2005). Warming of the world ocean, 1955-2003. Geophysical Research Letters 32(2).

Levitus, S., J. I. Antonov, J. Wang, T. L. Delworth, K. W. Dixon, and A. J. Broccoli (2001). Anthropogenic warming of earth's climate system. Science 292(5515), 267-270.

Locarnini, R., A. Mishonov, J. Antonov, T. Boyer, H. Garcia, O. Baranova, M. Zweng, C. Paver, J. Reagan, D. Johnson, M. Hamilton, and D. Seidov (2013). World ocean atlas 2013, volume 1: Temperature. NOAA Atlas NESDIS 73, 40.

Lu, J., R. J. Greatbatch, and K. A. Peterson (2004). Trend in northern hemisphere winter atmospheric circulation during the last half of the twentieth century. Journal of Climate 17(19), 3745-3760. 
Lumpkin, R. and S. Garzoli (2011). Interannual to decadal changes in the western south atlantic's surface circulation. Journal of Geophysical Research: Oceans (19782012) $116(\mathrm{C} 1)$.

Lutjeharms, J. and R. Van Ballegooyen (1984). Topographic control in the agulhas current system. Deep Sea Research Part A. Oceanographic Research Papers 31(11), 1321-1337.

Lutjeharms, J. and R. Van Ballegooyen (1988). The retroflection of the agulhas current. Journal of Physical Oceanography 18(11), 1570-1583.

Lynch-Stieglitz, J., J. F. Adkins, W. B. Curry, T. Dokken, I. R. Hall, J. C. Herguera, J. J.-M. Hirschi, E. V. Ivanova, C. Kissel, O. Marchal, et al. (2007). Atlantic meridional overturning circulation during the last glacial maximum. science 316(5821), 66-69.

Macdonald, A. M. and C. Wunsch (1996). An estimate of global ocean circulation and heat fluxes. Nature 382(6590), 436.

Mackintosh, N. A. (1946). The Antarctic Convergence and the distribution of surface temperatures in Antarctic waters. University Press.

Meinen, C. S., S. Speich, R. C. Perez, S. Dong, A. R. Piola, S. L. Garzoli, M. O. Baringer, S. Gladyshev, and E. J. Campos (2013). Temporal variability of the meridional overturning circulation at $34.5 \mathrm{~s}$ : Results from two pilot boundary arrays in the south atlantic. Journal of Geophysical Research: Oceans 118(12), 6461-6478.

Mogensen, K., M. A. Balmaseda, and A. Weaver (2012). The NEMOVAR ocean data assimilation system as implemented in the ECMWF ocean analysis for System 4. European Centre for Medium-Range Weather Forecasts.

Moore, J. K., M. R. Abbott, and J. G. Richman (1999). Location and dynamics of the antarctic polar front from satellite sea surface temperature data. Journal of Geophysical Research 104(C2).

Nitta, T. and S. Yamada (1989). Recent warming of tropical sea surface temperature and its relationship to the northern hemisphere circulation. Journal of the Meteorological Society of Japan. Ser. II 67(3), 375-383.

Orsi, A. and C. Wiederwohl (2009). A recount of ross sea waters. Deep-Sea Research II $56,778-795$.

Orsi, A., D. Worth, and T. Whitworth (1993). On the circulation and stratification of the weddell gyre. Deep-Sea Research I 40(1), 169-203.

Orsi, A. H., T. Whitworth, and W. D. Nowlin (1995). On the meridional extent and fronts of the antarctic circumpolar current. Deep Sea Research Part I: Oceanographic Research Papers 42(5), 641-673. 
Ou, H. W. and W. P. De Ruijter (1986). Separation of an inertial boundary current from a curved coastline. Journal of Physical Oceanography 16(2), 280-289.

Palastanga, V., P. Van Leeuwen, M. Schouten, and W. De Ruijter (2007). Flow structure and variability in the subtropical indian ocean: Instability of the south indian ocean countercurrent. Journal of Geophysical Research: Oceans 112(C1).

Peeters, F. J., R. Acheson, G.-J. A. Brummer, W. P. De Ruijter, R. R. Schneider, G. M. Ganssen, E. Ufkes, and D. Kroon (2004). Vigorous exchange between the indian and atlantic oceans at the end of the past five glacial periods. Nature 430 (7000), 661-665.

Penven, P., J. Lutjeharms, and P. Florenchie (2006). Madagascar: A pacemaker for the agulhas current system? Geophysical Research Letters $33(17)$.

Peterson, R. G. and L. Stramma (1991). Upper-level circulation in the south atlantic ocean. Progress in oceanography 26(1), 1-73.

Piola, A. and R. Matano (2001). Brazil and falklands (malvinas) currents. Ocean Currents: A Derivative of the Encyclopedia of Ocean Sciences, 35-43.

Quartly, G. and M. Srokosz (1993). Seasonal variations in the region of the agulhas retroflection: Studies with geosat and fram. Journal of Physical Oceanography 23(9), $2107-2124$.

Rahmstorf, S. (1995). Bifurcation of the atlantic thermohaline circulation in response to changes in the hydrological cycle. Nature 378, 9.

Reason, C., R. Allan, and J. Lindesay (1996). Evidence for the influence of remote forcing on interdecadal variability in the southern indian ocean. Journal of Geophysical Research: Oceans 101(C5), 11867-11882.

Rintoul, S. R., C. Hughes, and D. Olbers (1999). The antarctic circumpolar current system. Oceans and Climate, G. Siedler and J. Church,(eds.), Academic Press.

Robbins, P. E. and J. M. Toole (1997). The dissolved silica budget as a constraint on the meridional overturning circulation of the indian ocean. Deep Sea Research Part I: Oceanographic Research Papers 44(5), 879-906.

Rouault, M., P. Penven, and B. Pohl (2009). Warming in the agulhas current system since the 1980's. Geophysical Research Letters 36(12), L12602.

Ruijter, W. d., A. Biastoch, S. Drijfhout, J. Lutjeharms, R. Matano, T. Pichevin, P. v. Leeuwen, and W. Weijer (1999). Indian-atlantic interocean exchange: Dynamics, estimation and impact. Journal of Geophysical Research: Oceans 104(C9), 20885-20910.

Schott, F. A., S.-P. Xie, and J. P. McCreary (2009). Indian ocean circulation and climate variability. Reviews of Geophysics $47(1)$. 
Siedler, G., M. Rouault, and J. R. Lutjeharms (2006). Structure and origin of the subtropical south indian ocean countercurrent. Geophysical research letters $33(24)$.

Silveira, I. C. A., A. C. K. Schmidt, E. J. D. Campos, S. Godoi, and Y. Ikeda (2000). A corrente do brasil ao largo da costa leste brasileira. Rev. Bras. Ocean 48(2), 171-183.

Sloyan, B. M. and S. R. Rintoul (2001). Circulation, renewal, and modification of antarctic mode and intermediate water. Journal of Physical Oceanography 31(4), 1005-1030.

Smith, R., P. Jones, B. Briegleb, F. Bryan, G. Danabasoglu, J. Dennis, J. Dukowicz, C. Eden, B. Fox-Kemper, P. Gent, et al. (2010). The parallel ocean program (pop) reference manual ocean component of the community climate system model (ccsm) and community earth system model (cesm). Rep. LAUR-01853 141, 1-140.

Smith, S. D. (1988). Coefficients for sea surface wind stress, heat flux, and wind profiles as a function of wind speed and temperature. Journal of Geophysical Research: Oceans 93(C12), 15467-15472.

Sokolov, S. and S. R. Rintoul (2002). Structure of southern ocean fronts at 140 e. Journal of Marine Systems 37(1), 151-184.

Sokolov, S. and S. R. Rintoul (2007). Multiple jets of the antarctic circumpolar current south of australia. Journal of Physical Oceanography 37(5), 1394-1412.

Sokolov, S. and S. R. Rintoul (2009a). Circumpolar structure and distribution of the antarctic circumpolar current fronts: 1. mean circumpolar paths. Journal of Geophysical Research: Oceans (1978-2012) 114(C11), C11018.

Sokolov, S. and S. R. Rintoul (2009b). Circumpolar structure and distribution of the antarctic circumpolar current fronts: 2. variability and relationship to sea surface height. Journal of Geophysical Research: Oceans (1978-2012) 114, C11019.

Sparrow, M. D., K. J. Heywood, J. Brown, and D. P. Stevens (1996). Current structure of the south indian ocean. Journal of Geophysical Research: Oceans 101(C3), 6377-6391.

Speich, S., B. Blanke, and W. Cai (2007). Atlantic meridional overturning circulation and the southern hemisphere supergyre. Geophysical Research Letters 34(23), L23614.

Stouffer, R. J., J. Yin, J. Gregory, K. Dixon, M. Spelman, W. Hurlin, A. Weaver, M. Eby, G. Flato, H. Hasumi, et al. (2006). Investigating the causes of the response of the thermohaline circulation to past and future climate changes. Journal of Climate 19(8), $1365-1387$.

Stramma, L. (1991). Geostrophic transport of the south equatorial current in the atlantic. Journal of Marine Research 49(2), 281-294. 
Stramma, L. (1992). The south indian ocean current. Journal of physical oceanography 22(4), 421-430.

Stramma, L. and J. R. Lutjeharms (1997). The flow field of the subtropical gyre of the south indian ocean. Journal of Geophysical Research: Oceans 102(C3), 5513-5530.

Stramma, L. and R. G. Peterson (1990). The south atlantic current. Journal of Physical Oceanography 20(6), 846-859.

Swart, S., S. Speich, I. J. Ansorge, and J. R. Lutjeharms (2010). An altimetry-based gravest empirical mode south of africa: 1. development and validation. Journal of Geophysical Research: Oceans 115, C03002.

Talley, L. D. (2013). Closure of the global overturning circulation through the indian, pacific, and southern oceans: Schematics and transports. Oceanography 26(1), 80-97.

Talley, L. D., G. Pickard, W. Emery, and J. Swift (2011). Descriptive physical oceanography: an introduction. Academic press.

Toole, J. M. and B. A. Warren (1993). A hydrographic section across the subtropical south indian ocean. Deep Sea Research Part I: Oceanographic Research Papers 40(10), 1973-2019.

van Sebille, E., L. M. Beal, and W. E. Johns (2011). Advective time scales of agulhas leakage to the north atlantic in surface drifter observations and the $3 \mathrm{~d}$ ofes model. Journal of Physical Oceanography 41(5), 1026-1034.

Wainer, I., P. Gent, and G. Goni (2000). Annual cycle of the brazil-malvinas confluence region in the national center for atmospheric research climate system model. Journal of Geophysical Research: Oceans (1978-2012) 105(C11), 26167-26177.

Weijer, W., B. M. Sloyan, M. E. Maltrud, N. Jeffery, M. W. Hecht, C. A. Hartin, E. van Sebille, I. Wainer, and L. Landrum (2012). The southern ocean and its climate in ccsm4. Journal of Climate 25 (8), 2652-2675.

Weijer, W. and E. Van Sebille (2014). Impact of agulhas leakage on the atlantic overturning circulation in the ccsm4. Journal of climate 27(1), 101-110.

Whitworth, T. and W. D. Nowlin (1987). Water masses and currents of the southern ocean at the greenwich meridian. Journal of Geophysical Research: Oceans (19782012) 92(C6), 6462-6476.

Zhang, D., R. Msadek, M. J. McPhaden, and T. Delworth (2011). Multidecadal variability of the north brazil current and its connection to the atlantic meridional overturning circulation. Journal of Geophysical Research: Oceans (1978-2012) 116(C4), C04012. 
Zhang, R. and T. L. Delworth (2005). Simulated tropical response to a substantial weakening of the atlantic thermohaline circulation. Journal of Climate 18(12), 1853-1860.

Zweng, M., J. Reagan, J. Antonov, R. Locarnini, A. Mishonov, T. Boyer, H. Garcia, O. Baranova, D. Johnson, D. Seidov, et al. (2013). World ocean atlas 2013, volume 2: Salinity. NOAA Atlas NESDIS 74, 39. 


\section{Supplementary Figures}
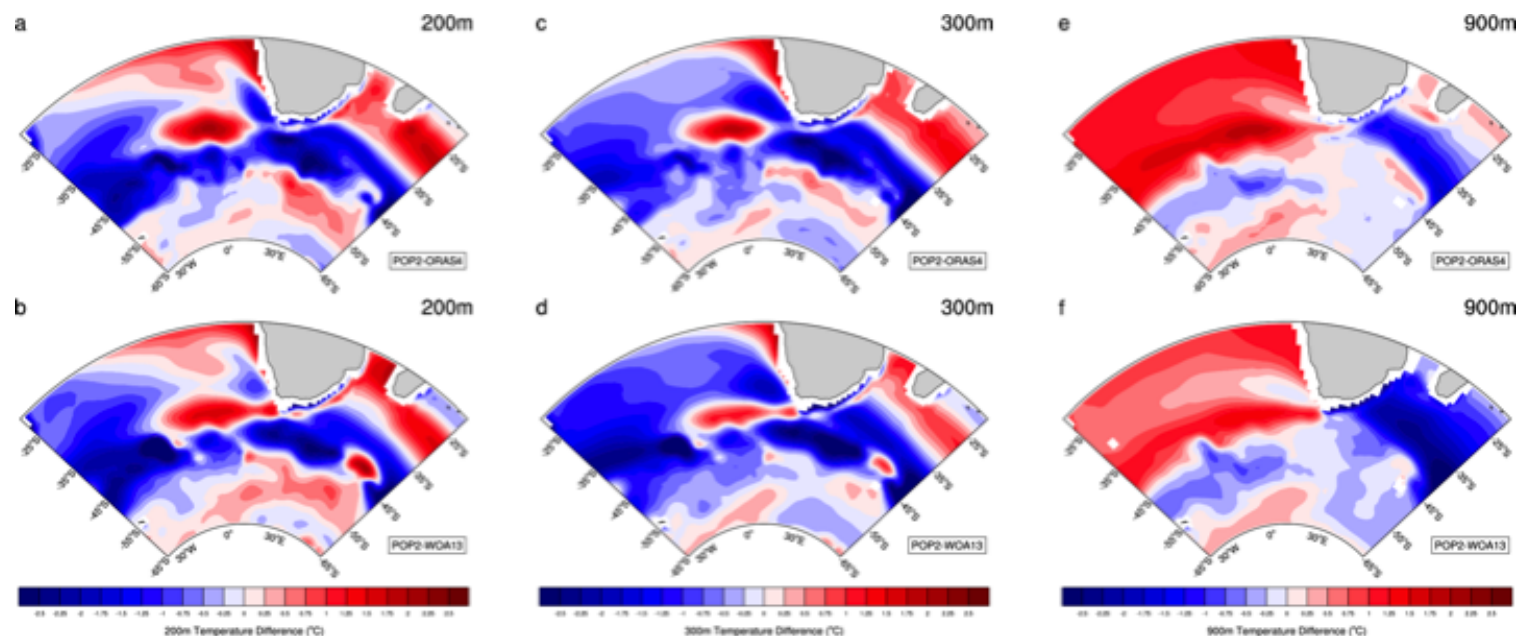

Figure 7.1: Difference between mean temperature fields at (a,b) 200 m, (c, d) 300 m, (e, f) $900 \mathrm{~m}$ between POP2-ORAS4 and POP2-WOA13.
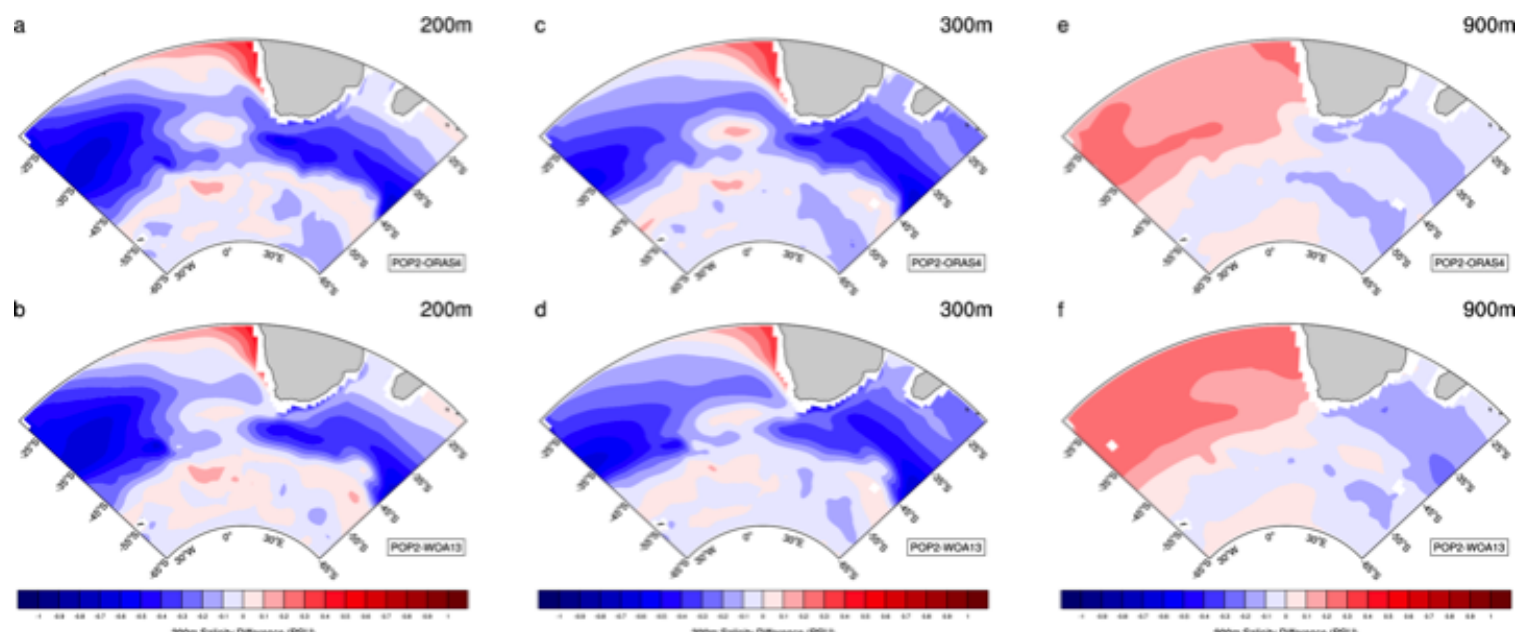

Figure 7.2: Difference between mean salinity fields at (a,b) 200 m, (c, d) 300 m, (e, f) 900 $\mathrm{m}$ between POP2-ORAS4 and POP2-WOA13. 
a

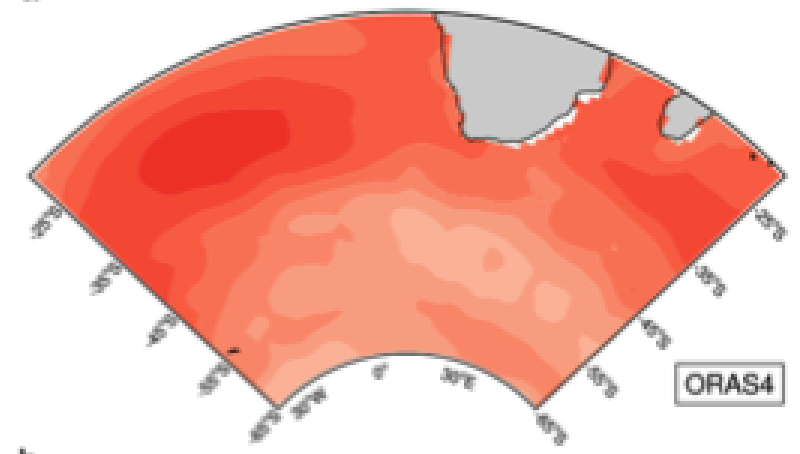

b

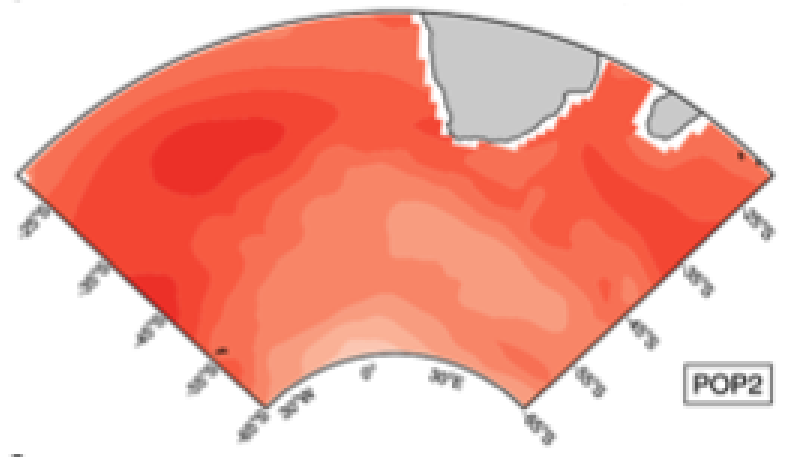

C

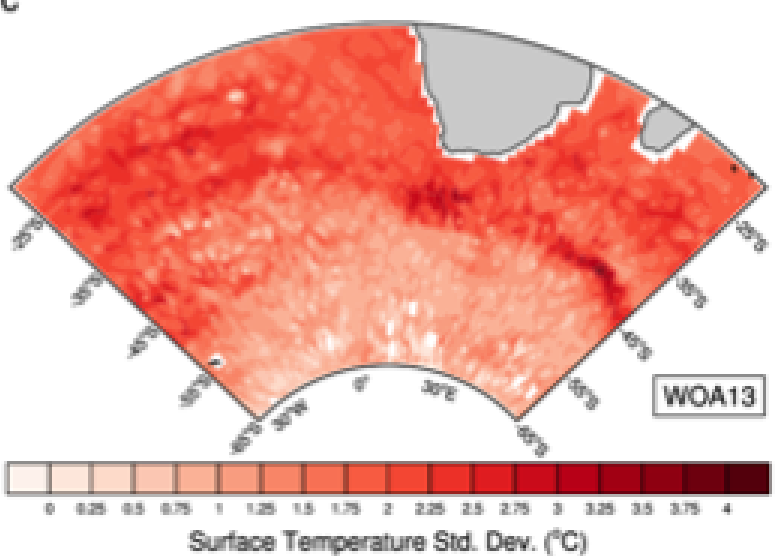

d

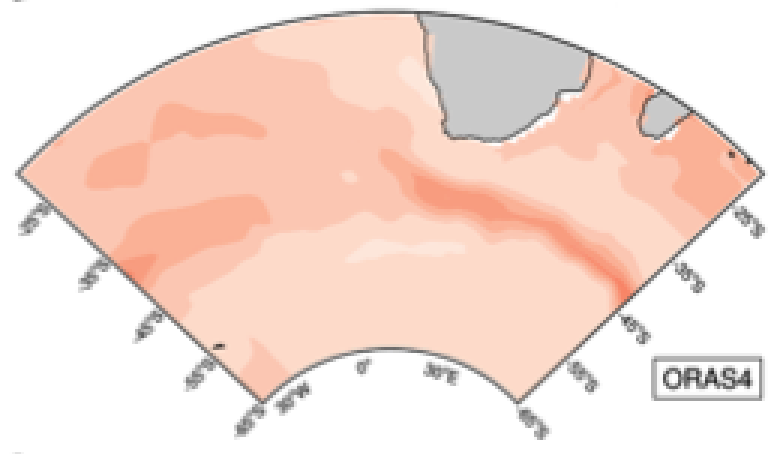

e

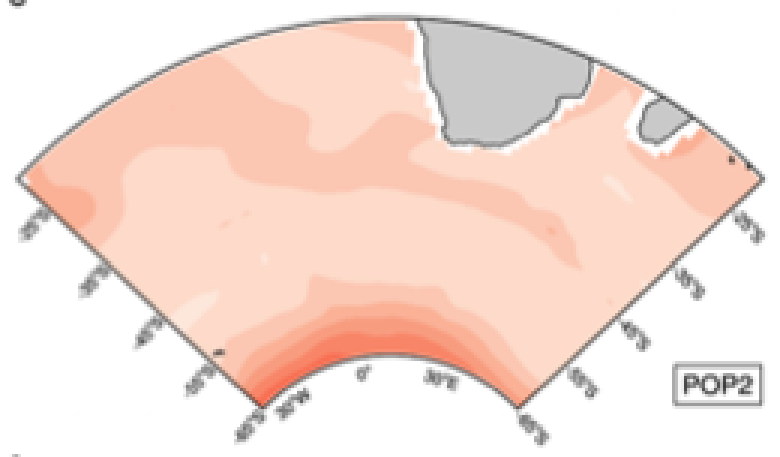

f

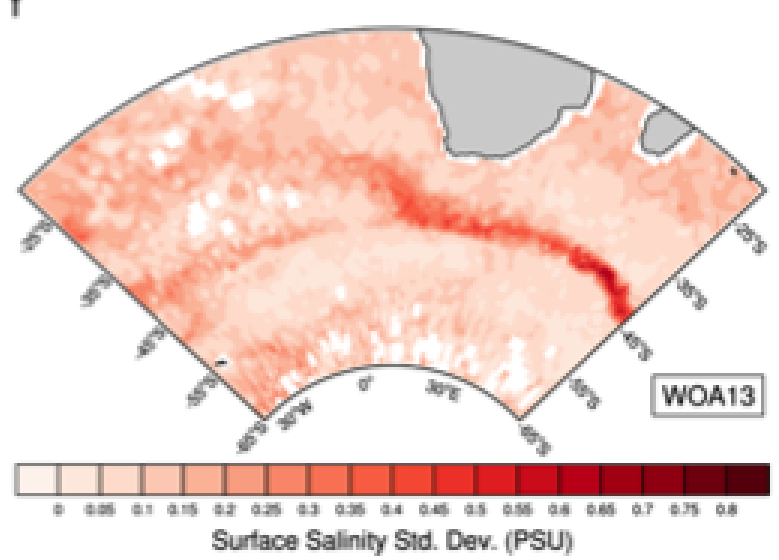

Figure 7.3: Standard deviation of (a-c) SST fields from ORAS4, POP2 and WOA13 respectively; (d to f) SSS fields from ORAS4, POP2 and WOA13 respectively. 

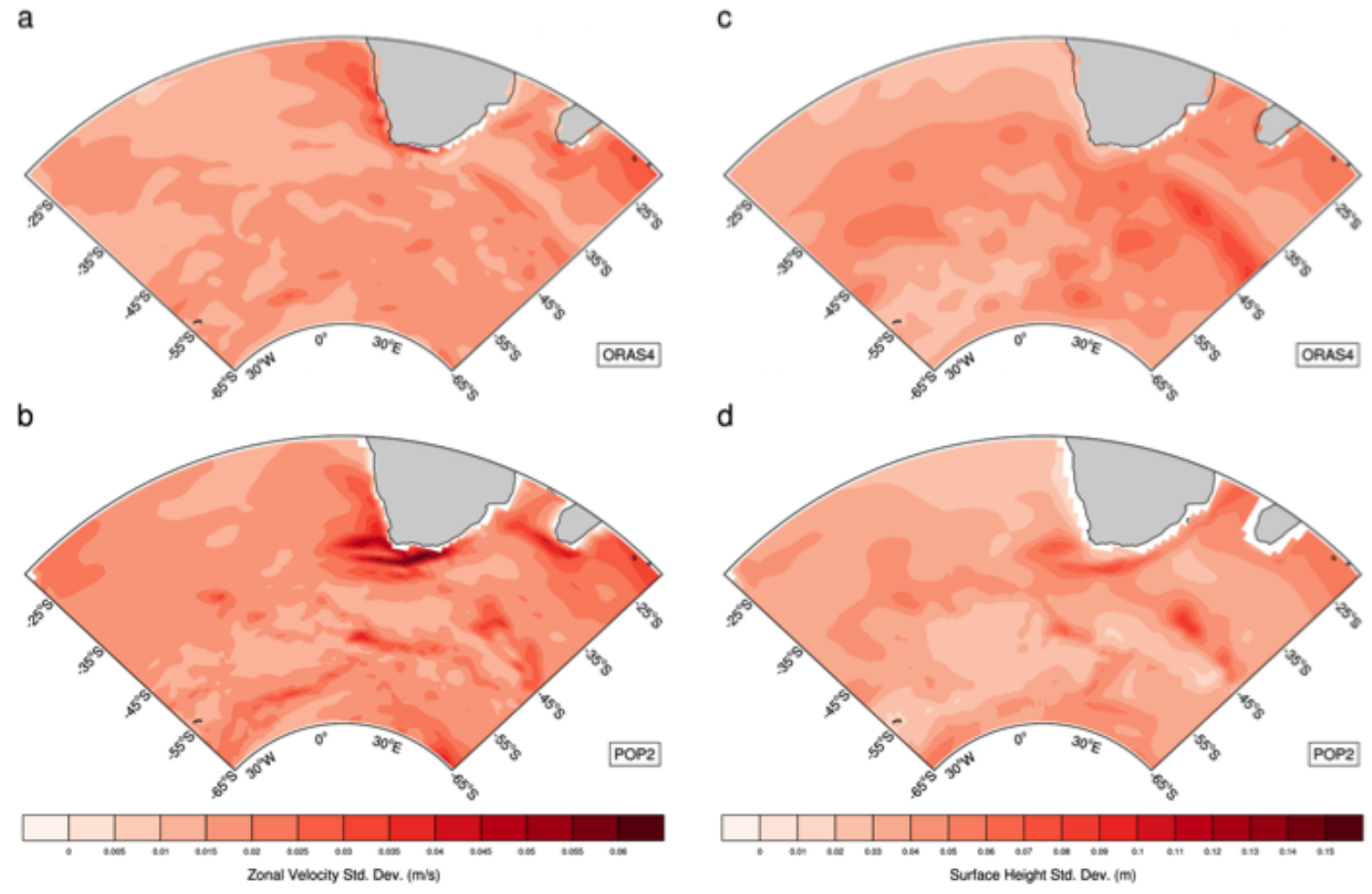

Figure 7.4: Standard deviation of $(\mathrm{a}, \mathrm{b})$ zonal velocity fields from ORAS4 and POP2 respectively; (c, d) SSH fields from ORAS4 and POP2 respectively. 


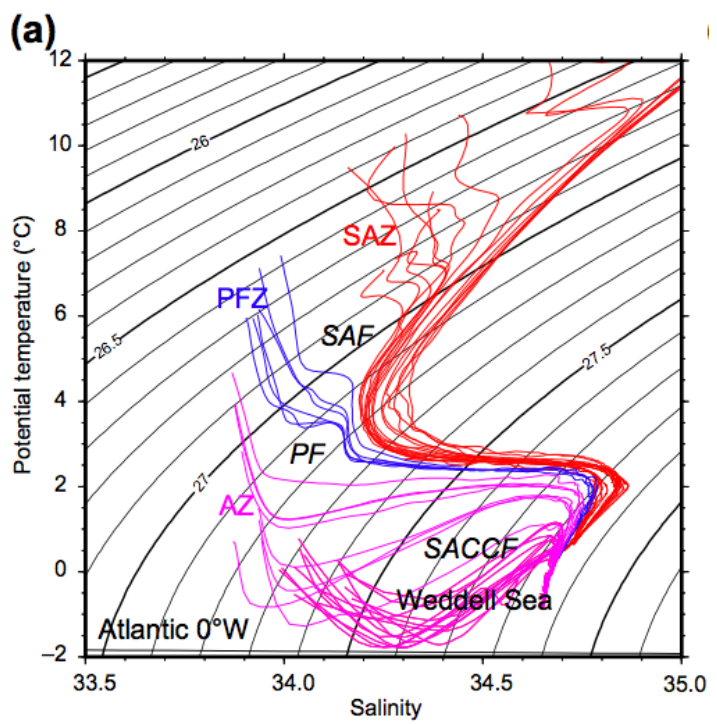

Figure 7.5: Figure 13.7 of Talley et al. (2011): Potential temperature-salinity relations for the Atlantic Ocean (Greenwich meridian), encompassing the fronts and zones of the ACC. Contours are potential density $\sigma_{-} \theta(\mathrm{kg} / \mathrm{m} 3)$. Line near bottom is the freezing point. Acronyms: SAZ (Subantarctic Zone), SAF (Subantarctic Front), PFZ (Polar Frontal Zone), PF (Polar Front), AZ (Antarctic Zone), SACCF (Southern ACC Front).

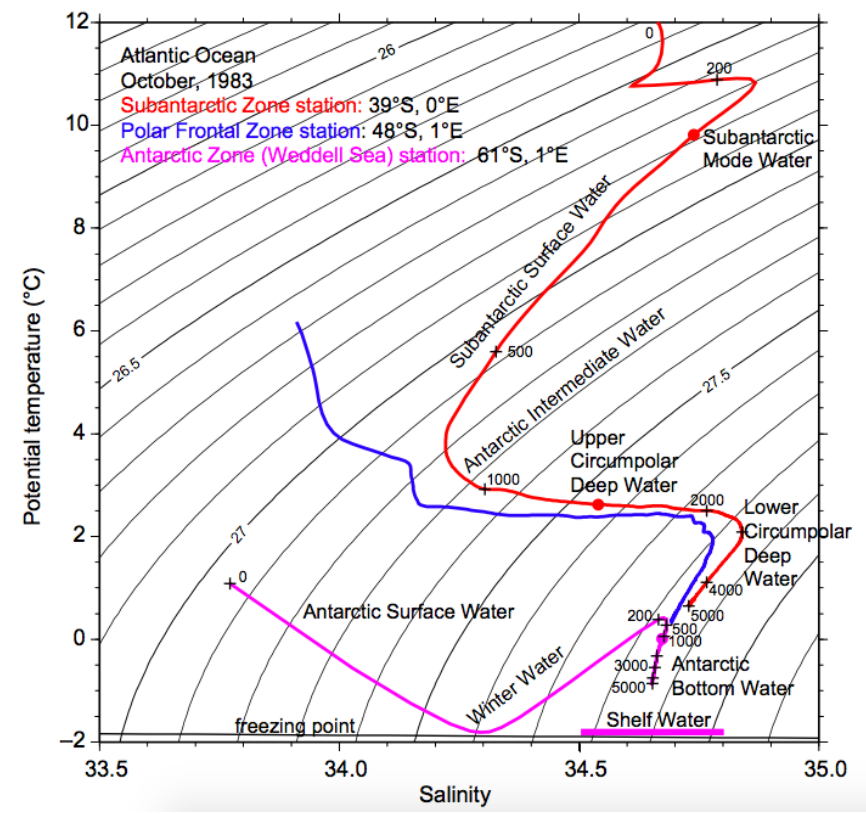

Figure 7.6: Figure 13.13 of Talley et al. (2011): Potential temperature-salinity curve of Southern Ocean waters in the Atlantic sector showing the different water masses. 